INTERNATIONAL MONETARY FUND

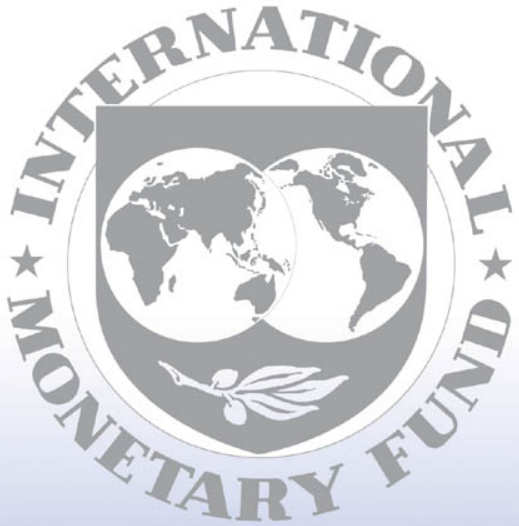

Staff

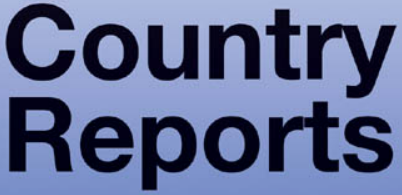




\title{
Chad: 2010 Article IV Consultation-Staff Report; Staff Supplements; Public Information Notice on the Executive Board Discussion; and Statement by the Executive Director for Chad
}

Under Article IV of the IMF's Articles of Agreement, the IMF holds bilateral discussions with members, usually every year. In the context of the 2010 Article IV consultation with Chad, the following documents have been released and are included in this package:

- The staff report for the 2010 Article IV consultation, prepared by a staff team of the IMF, following discussions that ended on April 27, 2010, with the officials of Chad on economic developments and policies. Based on information available at the time of these discussions, the staff report was completed on June 1,2010. The views expressed in the staff report are those of the staff team and do not necessarily reflect the views of the Executive Board of the IMF.

- A staff supplement on the joint IMF/World Bank debt sustainability analysis.

- $\quad$ A staff supplement of June 16, 2010, updating information on recent economic developments in Chad.

- $\quad$ A Public Information Notice (PIN) summarizing the views of the Executive Board as expressed during its June 16, 2010 discussion of the staff report that concluded the Article IV consultation.

- $\quad$ A statement by the Executive Director of Chad.

The policy of publication of staff reports and other documents allows for the deletion of market-sensitive information.

\author{
Copies of this report are available to the public from \\ International Monetary Fund • Publication Services \\ $70019^{\text {th }}$ Street, N.W. • Washington, D.C. 20431 \\ Telephone: (202) 623-7430 • Telefax: (202) 623-7201 \\ E-mail: publications@imf.org Internet: http://www.imf.org
}

Price: $\$ 18.00$ a copy

\section{International Monetary Fund Washington, D.C.}


INTERNATIONAL MONETARY FUND

CHAD

\title{
Staff Report for the 2010 Article IV Consultation
}

Prepared by the Staff Representatives for the 2010 Consultation with Chad

Approved by Seán Nolan and Dhaneshwar Ghura

June 1,2010

\begin{abstract}
Discussions for the 2010 Article IV consultations were held in N'djamena during March 4-17 and in Washington during April 23-27, 2010. The mission met with the Prime Minister and the Ministers of Finance and Budget, the Economy and Planning, Infrastructure, and Petroleum, members of the Finance Committee of the National Assembly, other senior officials, and representatives of the private sector, trade unions, civil society, and the donor/diplomatic community.

The staff team included Messrs. Josz (head), Ladd, Kinda (all AFR) and Petit (FAD) and was assisted by Mr. Karangwa (Resident Representative).

The last Article IV consultation was concluded on January 28, 2009. At that time, Directors highlighted the critical importance of improving fiscal management to achieve medium-term fiscal policy objectives, improve the quality of public spending, and eliminate budgetary overruns.

Exchange rate regime. Chad is a member of the Central African Economic and Monetary Community (CEMAC). Chad has accepted the obligations under Article VIII. The regional currency, the CFA franc (CFAF), is pegged to the Euro.
\end{abstract}




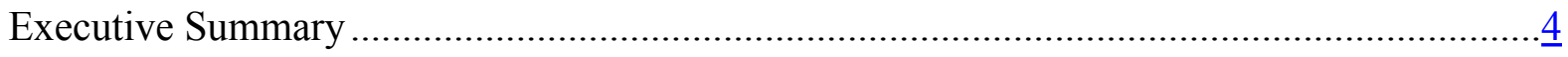

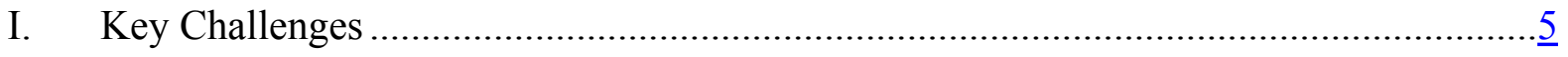

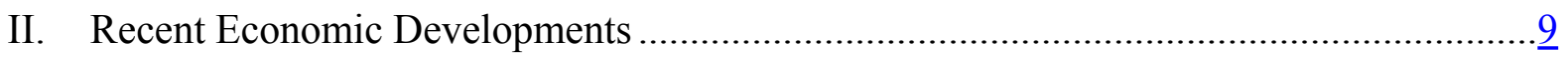

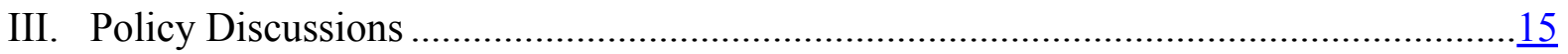

A. Measures to Address Food Shortages .............................................................15

B. Medium-Term Macroeconomic Outlook ……………………………………....16

C. Anchoring Fiscal Policy in a Medium-Term Framework.................... 17

D. Improving Public Financial Management for Transforming Oil Resources into Higher Non-Oil Growth and Lower Poverty ...............................................21

E. Fostering Non-Oil Sector Growth.........................................................................

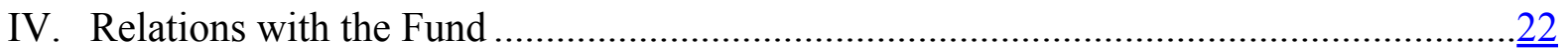

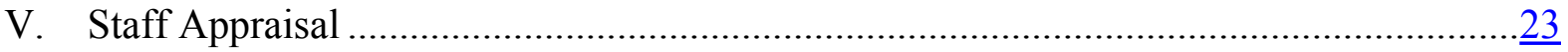

Boxes

1. Inflation Determinants ..................................................................................14

2. Real Effective Exchange Rate Assessment...........................................................

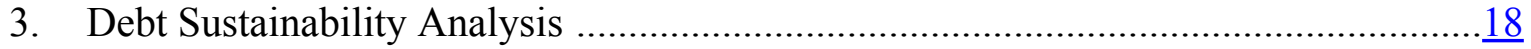

Text Tables

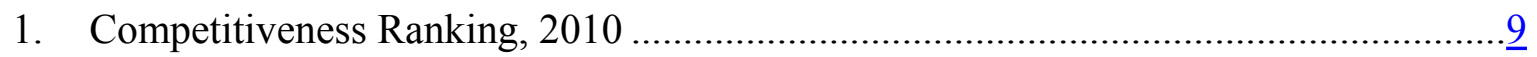

2. Fiscal Operations of the Central Government, 2008-09 ………….........................11

3. Compliance With CEMAC Convergence Criteria, 2003-09 ……………………......13

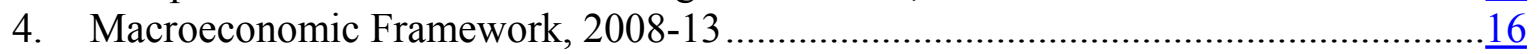

5. Fiscal Operations of the Central Government, 2009-11 .............................................

Figures

1. CEMAC Oil Production Horizons ………………..............................................

2. Progress Toward MDGs, 1990-2015 ………………………………………….....

3. Impact of Oil Production on Fiscal Policy and Public Financial Management, 2002-09

4. The Financial Sector is Underdeveloped Compared With African Low-Income

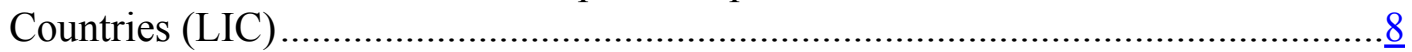

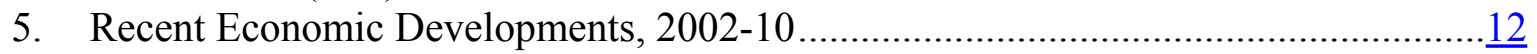

6. Total Revenue, Oil Revenue, and Non-Oil Revenue, 2000-31 ..................................19

7. Non-Oil Primary Balance (NOPB), 2000-20 ……………………………………......19

Tables

1. Selected Economic and Financial Indicators, 2008-13 …………………...............25

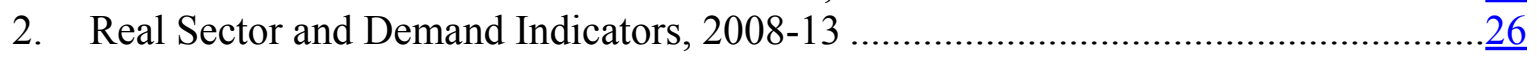


3. Fiscal Operations of the Central Government, 2008-13

(in billions of CFA francs)

4. Fiscal Operations of the Central Government, 2008-13

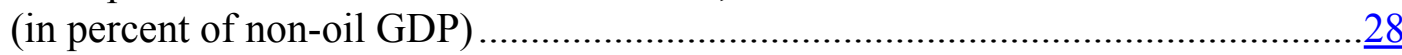

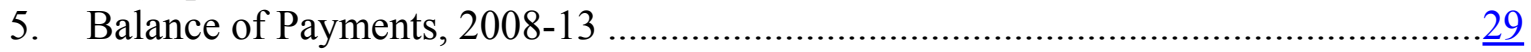

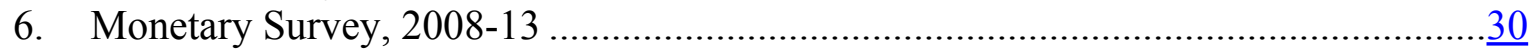

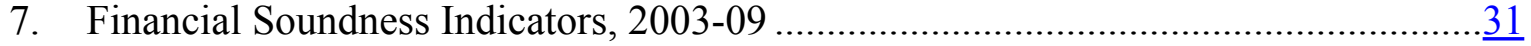

8. Selected Economic and Financial Indicators, 2008-15 .........................................

9. Millennium Development Goals, 1990-2008 ........................................................

10. Indicative Targets for the Period April 1 to October 31, 2009 and Projections

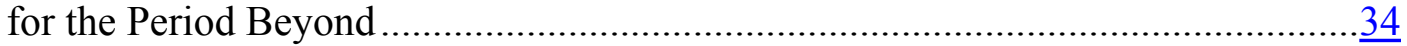

11. Prior Action and Structural Benchmarks for the Staff-Monitored Program

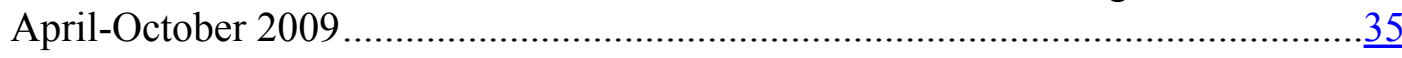




\section{EXECUTIVE SUMMARY}

Chad's chronic instability has hindered growth and poverty reduction. Despite collecting sizeable oil revenues since 2003, Chad remains among the poorest countries in the world and has made little progress towards the Millennium Development Goals (MDGs). The security situation is improving, thanks to a recent rapprochement between Chad and Sudan, but uncertainties remain.

Output contracted by 2 percent in 2009 because of a large drop in agricultural production due to poor rainfall and the trend decrease of oil production. Inflation reached 10 percent in 2009, but has started to wane in the aftermath of the fuel and food crisis.

The poor harvest could imply food shortages for up to 2 million people (18 percent of the population). The need for additional food is estimated at between 80,000-100,000 metric tons, which the government has started to meet in cooperation with donors.

The global financial crisis affected Chad mainly through the decline in oil prices. The fiscal position deteriorated sharply in 2009 as the government increased spending levels in the face of a fall-off in oil revenues by depleting its oil savings and borrowing from the regional central bank. The level of spending over 2008-09 was not sustainable; oil savings declined considerably and debt increased significantly during this period.

Medium-term fiscal policy needs to be set with an eye to the trend decline of oil resources over the next 20 years. Notwithstanding possible additional oil discoveries, the future trend in oil production is almost certainly downward. The staff recommends a fiscal adjustment strategy based on achieving a steady reduction of the non-oil primary deficit while focusing spending on priority areas. Absent a fiscal adjustment, the debt would rapidly reach unsustainable levels.

In 2010, the authorities should adopt a supplementary budget that accommodates underfunded priority spending while still targeting a significant reduction in the non-oil primary deficit. Further adjustment will be needed in 2011 given financing constraints.

Across-the-board improvement in public financial management is needed to transform oil resources into a higher level of human and physical capital than before the oil era. Improving the functioning of the judicial system, strengthening the financial sector, and reforming the state-owned cotton and utility companies are among the key measures needed to promote non-oil growth. 


\section{Key Challenges}

\section{Chad's chronically unstable security situation hinders growth and poverty} reduction. Chad is among the poorest countries in the world and has, as yet, made little progress towards the MDGs (Figure 2 and Table 9). It has experienced conflict for most of the past thirty years. The Darfur crisis and instability in the Central African Republic have driven about 300,000 refugees into Chad, adding to some 180,000 internally displaced persons. The recent rapprochement between Chad and Sudan has improved security, but uncertainties remain. Legislative elections are scheduled for November 2010 and presidential elections for April 2011.

\section{Chad's key medium term} challenge is to seize the opportunity provided by oil revenues to increase growth of the non-oil sector and reduce poverty. Seizing this opportunity requires prudent fiscal policy, anchored in a medium term framework, and strong public financial management. Rapid progress is needed because oil revenue is temporary, as production from the Doba basin is expected to diminish gradually until it becomes negligible by 2032 (Figure 1).

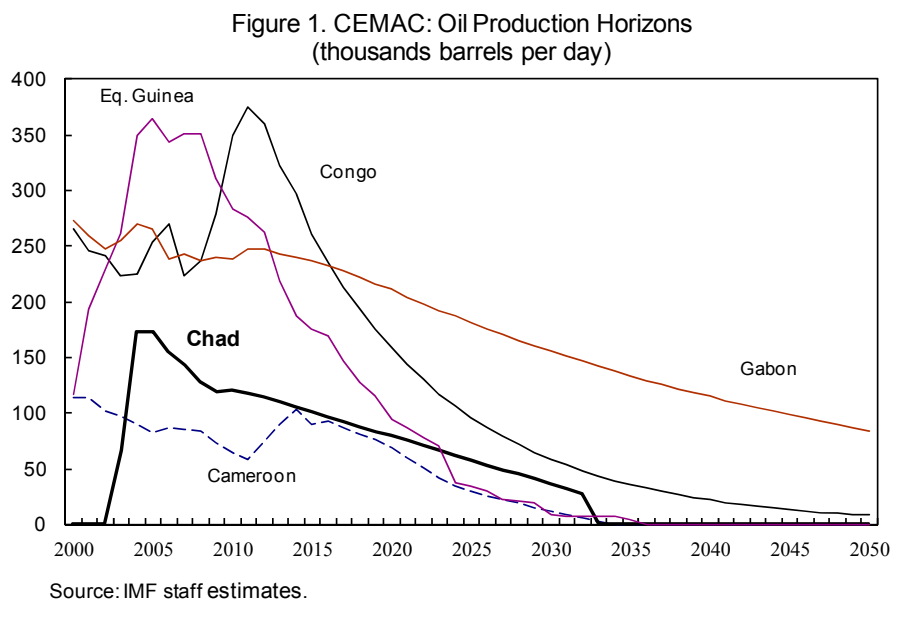

\section{So far, the oil-revenue windfall has set public expenditure on an unsustainable} path (Figure 3). Annual public expenditure has doubled (in percent of non-oil GDP) since 2003, reaching 46 percent of non-oil GDP in 2009. Oil revenue has fueled an increase not only in priority spending highlighted in the Poverty Reduction Strategy (PRS) but also in security outlays. The non-oil primary deficit has reached a level (28 percent of non-oil GDP in 2009) that is much higher than the long-run sustainable level (estimated in the low single digits) that would allow the transformation of the remaining oil bonanza of the next two decades into a permanent income stream. ${ }^{1}$

\footnotetext{
${ }^{1}$ For estimations of the sustainable non oil primary balance in Chad, see IMF Country Report No. 09/68; Chad: 2008 Article IV Consultation; Staff Report; Box 1, p.13 and IMF Country Report No. 09/67; Chad--Selected Issues; Chapter II.
} 
Figure 2. Chad: Progress Toward MDGs, 1990-2015
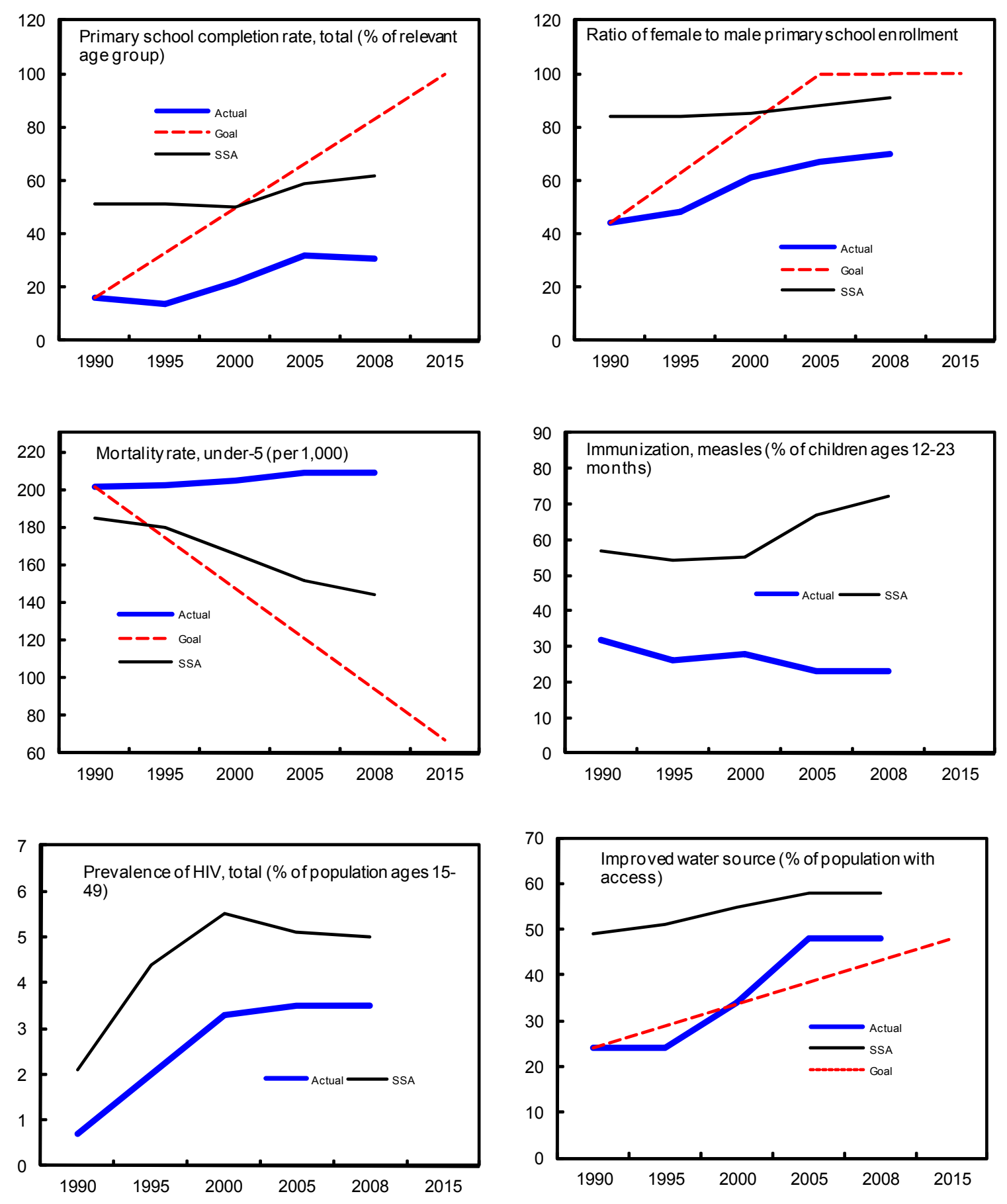

Source: World Bank, World Development Indicators database. 
Figure 3. Chad: Impact of Oil Production on Fiscal Policy and Public Financial Management, 2002-09

The start of oil production has radically improved government revenue...

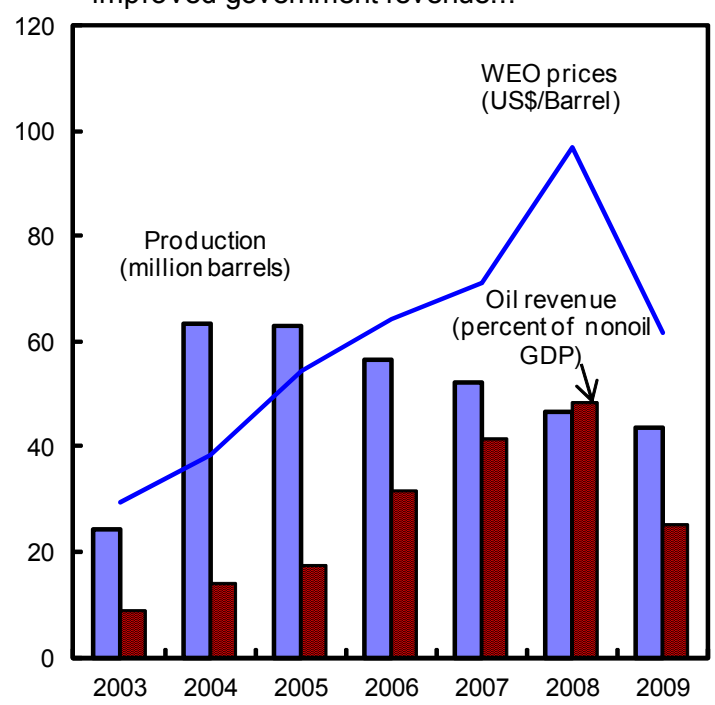

... in priority PRSP spending but also military spending given the tense security

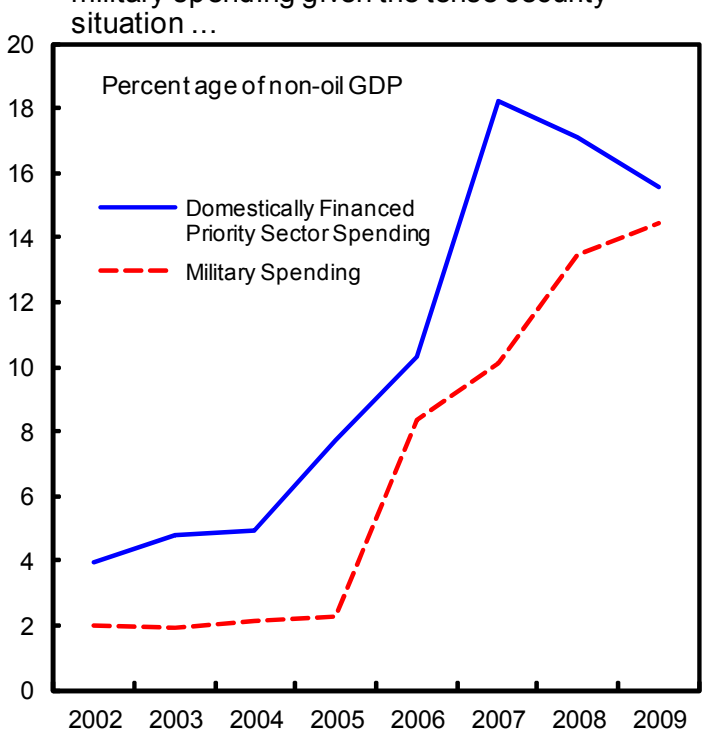

...financing a large increase in government spending ...

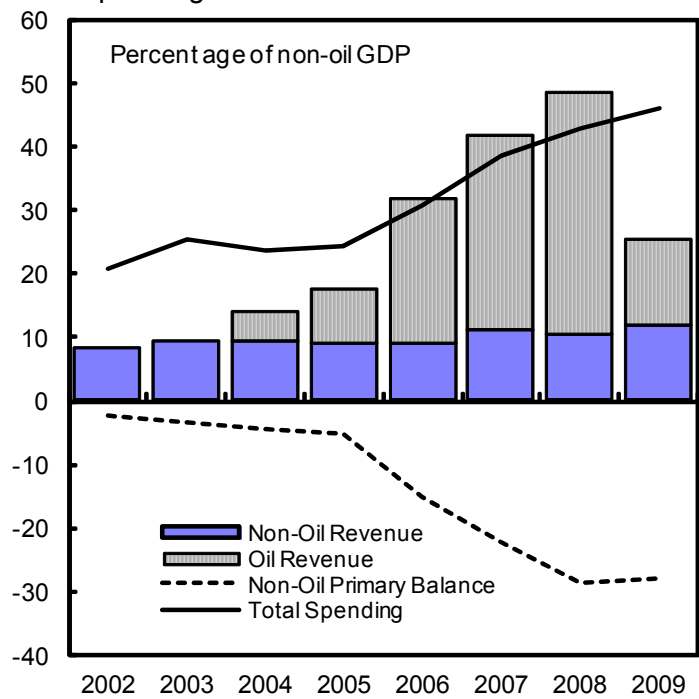

...while normal budget procedures have been increasingly bypassed.

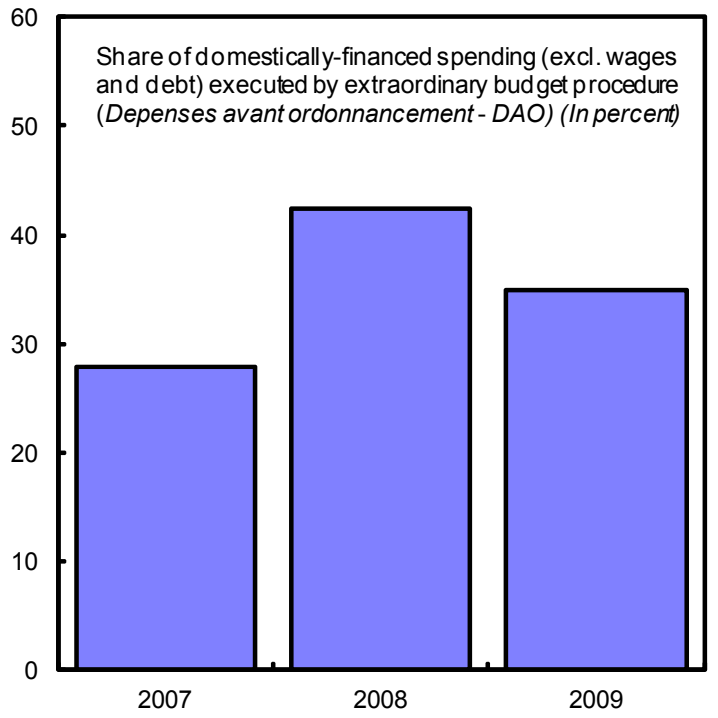

Sources: Chadian authorities and staff estimates. 


\section{This fiscal expansion has strained absorptive capacity and public financial} management (PFM) and raised governance concerns. Concerns over absorptive capacity are prompted by the conjunction of fast growth of investment spending and the insufficient attention given to the multi-year implications of investment decisions, including allocations for recurrent spending in health and education. Concerns over PFM relate to weak links between annual budgets and the PRS, and the limited role of line ministries in elaborating their budgets. Concerns over governance are due to weak procurement practices and the frequent bypassing of normal budget procedures (Figure 3).

\section{In recent years, Chad's performance under Fund-supported programs has been} weak, while relations with some important development partners have been difficult. The last arrangement under the Poverty Reduction and Growth Facility (now Extended Credit Facility), which covered the period February 2005-May 2008, expired without the completion of any review, reflecting recurring fiscal slippages and poor performance in strengthening PFM. A Staff-Monitored Program (SMP) covering April-October 2009 went off-track because of large spending overruns ( $\mid 11)$. Following differences on the scale and quality of spending financed by oil revenues, the World Bank asked Chad to prepay all oil pipeline-related loans in September 2008. The Bank has begun to re-engage with the authorities outside the oil sector. ${ }^{2}$ Weak macroeconomic policy performance and limited progress towards other triggers have prevented Chad from reaching the completion point under the Enhanced Heavily Indebted Poor Country (HIPC) Initiative.

\section{The financial system is} shallow. Compared to other African low-income countries, monetization is low and credit to the private sector is small, both of which constrain the development of the private sector (Figure 4).

\section{Chad's overall business} environment is very difficult. In international rankings, Chad persistently ranks among the bottom 10 percent of countries (Text Table 1).
Figure 4. Chad: The Financial Sector is Underdeveloped Compared With African Low-income Countries (LIC)

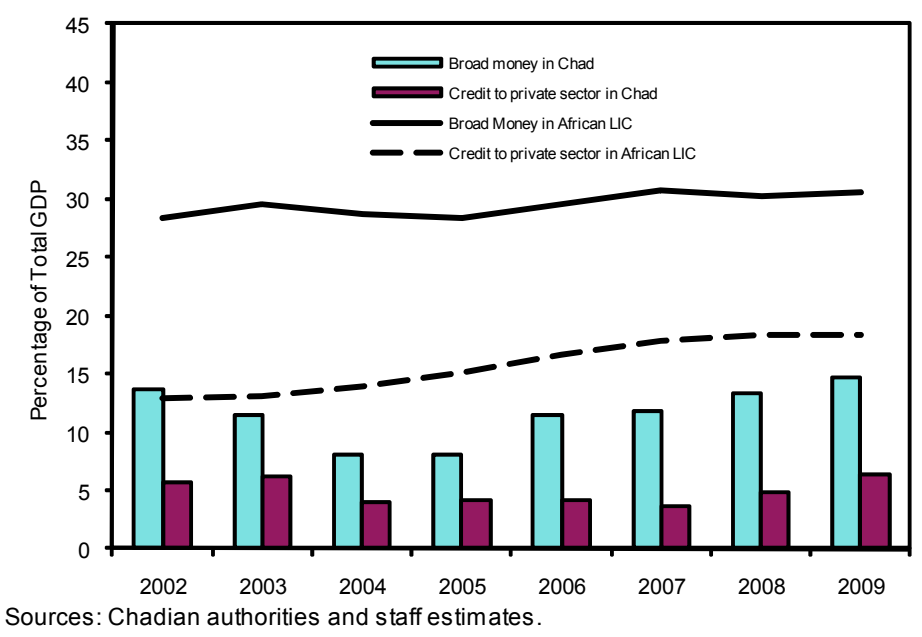

\footnotetext{
${ }^{2}$ Chad-Staff Report for the 2010 Article IV Consultation-Informational Annex, p. 7.
} 


\begin{tabular}{|c|c|c|c|}
\hline \multicolumn{4}{|c|}{ Text Table 1. Chad: Competitiveness Rankings, 2010} \\
\hline \multirow{2}{*}{\multicolumn{2}{|c|}{$\begin{array}{l}\text { Global Competitiveness Index 2009-2010 } \\
\text { (Out of } 133 \text { countries, best=1, worst=133) } \\
\text { Chad ranks very low on infrastructure, higher } \\
\text { education, health and governance, but "better" } \\
\text { on macroeconomic stability. }\end{array}$}} & \multirow{2}{*}{\multicolumn{2}{|c|}{$\begin{array}{c}\text { Doing Business Indicators } 2010 \\
\text { (Out of } 183 \text { countries, best=1, worst=183) } \\
\text { Chad ranks very low on starting and closing a } \\
\text { business, but "better" on dealing with } \\
\text { construction permits. }\end{array}$}} \\
\hline & & & \\
\hline Overall ranking of Chad & 131 & Overall ranking of Chad & 178 \\
\hline Subcategories: & & Subcategories: & \\
\hline Macroeconomic stability & 82 & Dealing with Construction Permits & 73 \\
\hline Labor market efficiency & 102 & Employing workers & 118 \\
\hline Innovation & 120 & Protecting investors & 132 \\
\hline Technological readiness & 127 & Paying taxes & 133 \\
\hline Business sophistication & 129 & Registering property & 136 \\
\hline Institutions/Governance & 131 & Getting credit & 150 \\
\hline Health and primary education & 133 & Trading across borders & 169 \\
\hline Goods market efficiency & 133 & Enforcing contracts & 170 \\
\hline Higher education and training & 133 & Starting a business & 182 \\
\hline Infrastructure & 133 & & \\
\hline \multicolumn{2}{|l|}{ Source: World Economic Forum. } & Source: World Bank. & \\
\hline
\end{tabular}

8. The government adopted a new PRS in April 2008. The PRS highlights the importance of restoring security, fiscal sustainability, sound public financial management, and high-quality spending to promote diversification of the economy and reduce poverty. ${ }^{3}$

\section{RECENT ECONOMIC DEVELOPMENTS}

9. Output dropped in 2009 and inflation has started to decline (Tables 1-2 and Figure 5). Real GDP contracted by 2 percent because of a sharp reduction in agricultural production due to poor rainfall and the trend decrease of oil production (Figure 2). Inflation (up from 8 percent on average in 2008 to 10 percent in 2009) has started to wane in the aftermath of the fuel and food crisis. Developments in rainfall, public spending, trading partner prices, and exchange rate movements have been the main determinants of inflation over time (Box 1).

10. The real effective exchange rate (REER) has appreciated over the past several years, reflecting the effects of a strong euro and surging public spending levels (Figure 5). Recent euro weakening (if sustained) and eventual fiscal adjustment (\$22) will likely yield

\footnotetext{
${ }^{3}$ Chad-Poverty Reduction Strategy Paper (www.imf.org); and Chad_Poverty Reduction Strategy PaperJoint Staff Advisory Note (www.imf.org).
} 
real depreciation in the coming years. ${ }^{4}$ Application of conventional methodologies does not point to significant overvaluation vis-à-vis fundamentals (Box 2).

11. The fiscal position deteriorated sharply in 2009 as the government increased spending levels while oil revenues fell (Text Table 2, Tables 3-4 and Figure 3).

- Oil revenues fell sharply (from 38 percent of non-oil GDP in 2008 to 13 percent in 2009) because of the drop in world oil prices and the advancement of oil tax payments from 2009 to 2008 as agreed with the oil consortium. ${ }^{5}$

- Expenditure increased (from 43 percent of non-oil GDP in 2008 to 46 percent in 2009) and exceeded (by large margins) the expenditure ceilings under both the initial budget approved in December 2008 and the supplementary budget approved in August 2009 under the SMP.

- The overall fiscal balance moved from a sizeable surplus (some 7 percent of non-oil GDP) in 2008 to a large deficit (about 21 percent of non-oil GDP) in 2009, which was financed by a mix of: (i) depletion of oil savings held at the BEAC; (ii) increased borrowing from BEAC (including the counterpart of Chad's new SDR allocation ${ }^{6}$ ); and (iii) significant increased foreign financing (mainly grants) to finance projects implemented by donors.

- The non-oil primary balance improved marginally in 2009 (by less than 1 percent of non-oil GDP), helped by improvement in non-oil tax revenues.

- The alignment of spending with PRS priorities (as measured by the share of priority spending in total primary spending) deteriorated in 2009 on account of a further increase in security outlays.

12. Chad's compliance with the macroeconomic convergence criteria of the Central African Economic and Monetary Community (CEMAC) has deteriorated since 2007, due to the worsening of its fiscal position and high inflation (Text Table 3).

\footnotetext{
${ }^{4}$ A recent regional external sustainability assessment also found that the CEMAC region's REER's alignment with fundamentals hinges on fiscal adjustment.

5 IMF Country Report No. 09/206: Chad: Staff Monitored Program, Staff Report, paragraph 9, p.7.

${ }^{6}$ Chad benefitted from an additional SDR allocation of SDR 44.2 million (CFA 32 billion or 1.4 percent of nonoil GDP) as a result of the US\$ 250 billion general SDR allocation and the fourth amendment of the Fund's Articles of Agreement; funding in this amount was then lent to the Government of Chad by BEAC.
} 
Text Table 2. Chad: Fiscal Operations of the Central Government, 2008-09 (In percent of non-oil GDP, unless otherwise indicated)

\begin{tabular}{|c|c|c|c|c|}
\hline & \multirow{2}{*}{$\begin{array}{c}2008 \\
\text { Est. }\end{array}$} & \multicolumn{3}{|c|}{2009} \\
\hline & & $\begin{array}{r}\text { Initial } \\
\text { Budget }\end{array}$ & $\begin{array}{r}\text { Revised } \\
\text { Budget }\end{array}$ & $\overline{\text { Est. }}$ \\
\hline Revenue & 48.6 & 31.9 & 15.9 & 25.2 \\
\hline Oil revenue & 38.2 & 22.4 & 4.3 & 13.2 \\
\hline Non-oil revenue & 10.3 & 9.5 & 11.6 & 11.9 \\
\hline Expenditure & 43.1 & 37.6 & 33.9 & 46.1 \\
\hline Current expenditure & 28.5 & 22.5 & 23.0 & 29.6 \\
\hline Investment expenditure & 14.6 & 15.1 & 10.9 & 16.5 \\
\hline Domestically financed & 10.8 & 9.4 & 7.6 & 11.3 \\
\hline Foreign financed & 3.7 & 5.7 & 3.2 & 5.2 \\
\hline Non-oil primary balance ${ }^{1}$ & -28.7 & -21.6 & -18.4 & -28.0 \\
\hline Overall balance (excl. grants, cash) & 6.7 & -6.2 & -18.6 & -20.8 \\
\hline Domestic financing & -7.9 & 2.0 & 16.4 & 15.4 \\
\hline Foreign financing & 1.2 & 4.2 & 2.2 & 5.5 \\
\hline \multicolumn{5}{|l|}{ Memorandum item: } \\
\hline Total military spending & 13.5 & 6.5 & 9.5 & 14.5 \\
\hline Priority spending (in percent of tot. exp. excl. int.) ${ }^{2}$ & 40.3 & 43.8 & 42.5 & 34.5 \\
\hline Deposits in banks (mostly BEAC) & 14.5 & 10.0 & 0.1 & 3.8 \\
\hline
\end{tabular}

Sources: Chadian authorities; and IMF staff estimates.

1. Defined in Table 3, footnote 3.

2. Defined in Table 3, footnote 5. 
Figure 5. Chad: RecentEconomic Developments, 2002-10
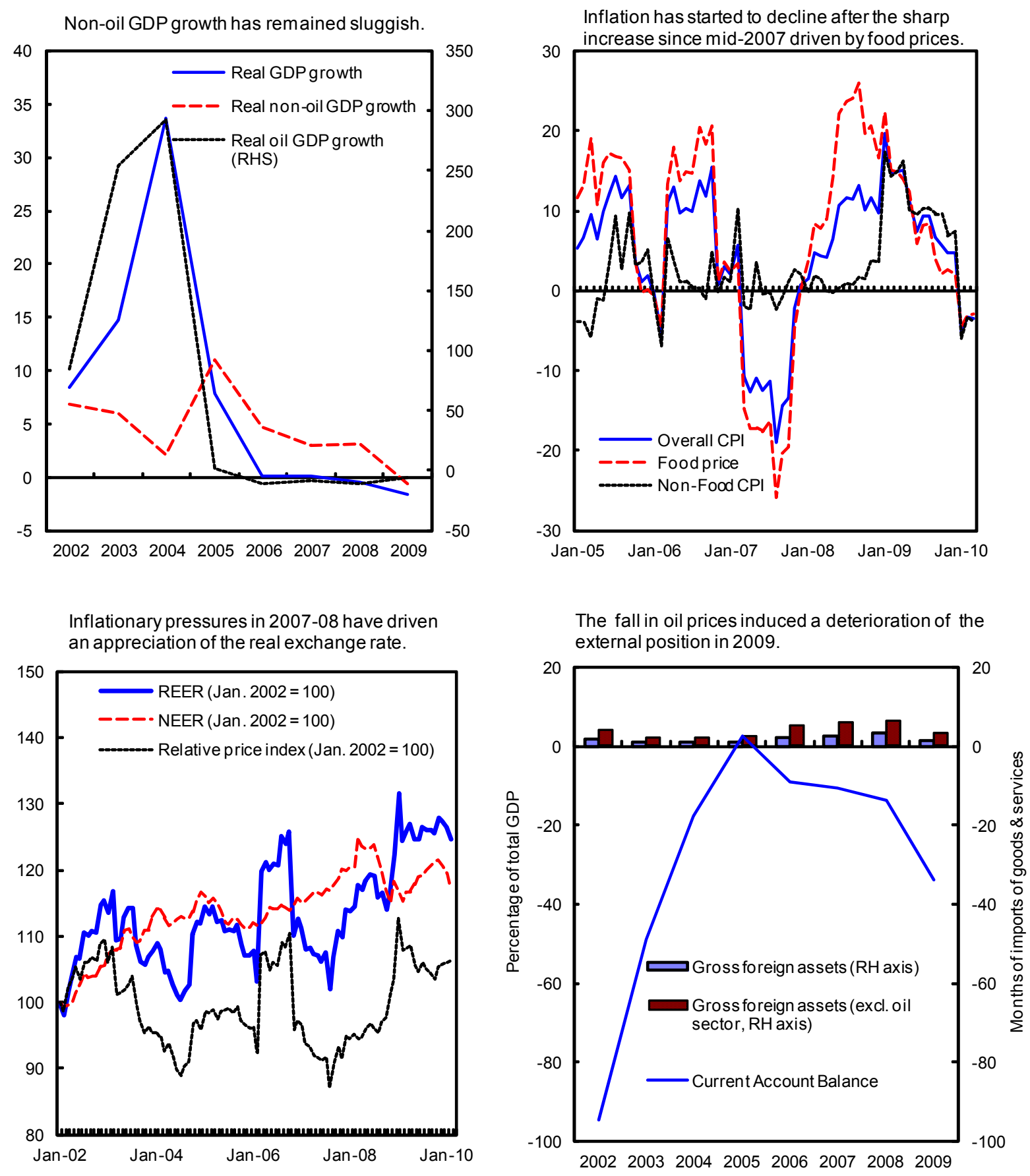

Source: Chadian authorities and staff estimates. 


\begin{tabular}{|c|c|c|c|c|c|c|c|}
\hline \multicolumn{8}{|c|}{$\begin{array}{l}\text { Text Table 3. Chad: Compliance with CEMAC Convergence Criteria, 2003-09 } \\
\text { (Percent of GDP unless otherwise indicated) }\end{array}$} \\
\hline & Criteria & 2004 & 2005 & 2006 & 2007 & 2008 & $\begin{array}{c}2009 \\
\text { Est. }\end{array}$ \\
\hline Basic fiscal balance $^{1}$ & $\geq 0$ & -0.2 & 1.1 & 3.8 & 4.3 & 5.0 & -10.4 \\
\hline Basic structural fiscal balance ${ }^{2}$ & $\geq 0$ & NA & NA & -2.2 & -1.4 & -0.2 & -2.5 \\
\hline Non-oil basic fiscal balance ${ }^{3}$ & $\geq 0$ & -5.1 & -6.7 & -15.8 & -22.7 & -28.7 & -28.0 \\
\hline CPI inflation (annual percentage change) & $\leq 3$ & -4.8 & 3.7 & 7.7 & -7.4 & 8.3 & 10.1 \\
\hline Stock of public debt & $\leq 70$ & 34.2 & 33.6 & 29.6 & 26.0 & 23.6 & 31.4 \\
\hline Net change in government arrears & $\leq 0$ & 0.9 & 0.1 & -0.2 & -0.6 & -2.4 & -2.6 \\
\hline \multicolumn{8}{|c|}{ In number of fulfilled criteria / total criteria } \\
\hline Chad's compliance (four main criteria) & & $2 / 4$ & $2 / 4$ & $3 / 4$ & $4 / 4$ & $3 / 4$ & $2 / 4$ \\
\hline Other CEMAC countries' compliance (four main criteria) & & $3 / 4$ & $3 / 4$ & $2 / 4$ & $3 / 4$ & $3 / 4$ & $3 / 4$ \\
\hline $\begin{array}{l}\text { Sources: Chadian authorities; staff estimates. } \\
\text { 1. Overall fiscal balance excluding grants and foreign-fina } \\
\text { 2. Same as basic fiscal balance, but replacing oil revenu } \\
\text { 3. Overall fiscal balance excluding oil revenue, grants an }\end{array}$ & $\begin{array}{l}\text { investn } \\
\text { average } \\
\text { aign-fina }\end{array}$ & ars $\mathrm{t}$ & & . & & & \\
\hline
\end{tabular}

13. Chad's balance of payments weakened in 2009 (Table 5 and Figure 5). The fall in oil prices induced a sharp increase of the current account deficit, a deterioration of the overall balance and a reduction of imputed gross official reserves (to 3 months of imports of goods and services, net of oil sector imports). ${ }^{7}$

14. Broad money contracted slightly in 2009 (Table 6), in part reflecting the drop in economic activity.

15. There are pockets of vulnerability in the financial system (Table 7). The balance sheets of the eight banks, most of which are foreign-owned, have not been directly impacted by the crisis in advanced countries, given their limited exposure to international financial markets. But the banking sector remains subject to vulnerabilities, stemming from its lack of depth, high credit concentration, the fragile situation of some banks, insufficient on-site supervision, the poor functioning of the judiciary system, and, more broadly, the underdevelopment of financial markets in the CEMAC.

16. Progress in microeconomic reforms has been limited. The state-owned cotton company continued to need budget transfers (in an amount of 1.3 percent of non-oil GDP in 2009) to absorb losses stemming from low international cotton prices, declining production, and weak management. The state water and electricity company also needed budget transfers (of 0.8 percent of non-oil GDP in 2009) to cover losses stemming from low collections, uncompetitive oil procurement, and poor overall management that contributed to frequent power outages.

\footnotetext{
${ }^{7}$ Given that the oil consortium finances its large imports needs for developing the oil field with its own means, the relevant metric for monitoring the level of imputed foreign exchange reserves is imports of goods and services excluding oil sector imports.
} 


\section{Box 1. Chad: Inflation Determinants}

On average inflation has been moderate but has increased recently. Inflation averaged 5 percent per annum during 1983-2009, although with sizeable year-to-year fluctuations (Figure A). Food prices have risen relative to non-food prices over the past three years (Figure B).

Figure A. Chad: Annual Inflation, 1983-2009

(Percent)

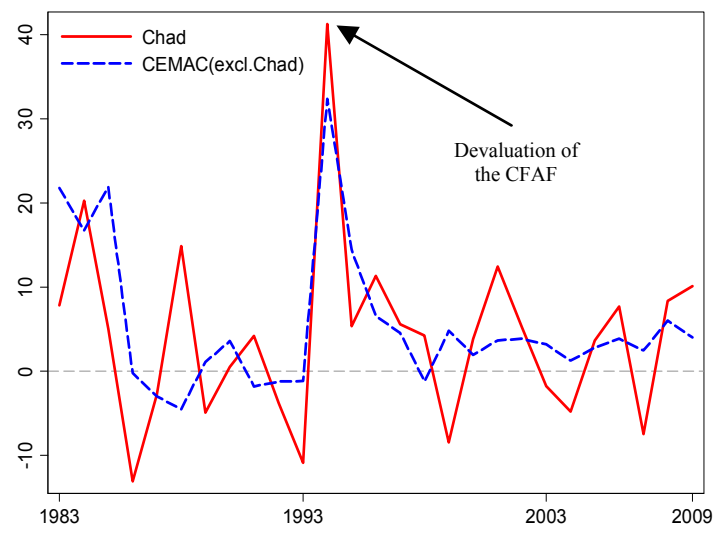

Figure B. Chad: Monthly Consumer and Food Price Indexes, 2005:12-2010:3

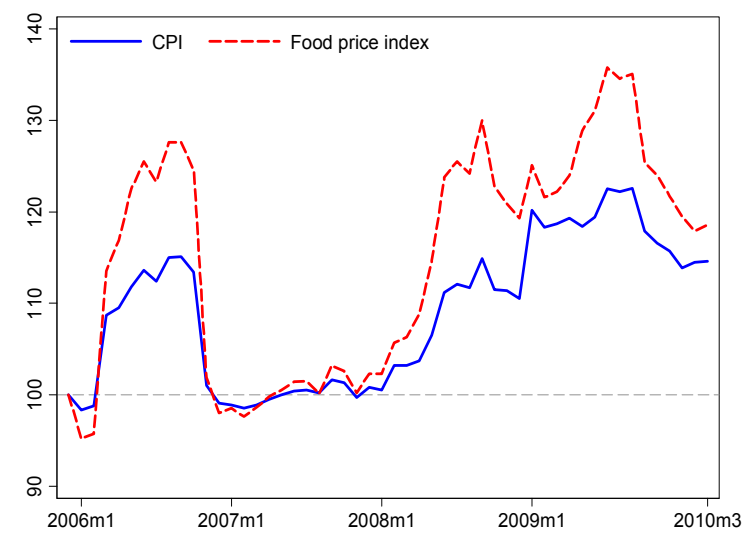

Rainfall, public spending, changes in trading partner prices, and exchange rate movements have been the main determinants of inflation. Rainfall affects domestic prices (with a three quarter lag) through its impact on agriculture. The start of oil production in 2003 fueled public spending which has a significant impact on inflation (with a one quarter lag) through demand pressures on nontradables. Changes in trading partner prices and nominal effective exchange rate movements are passed through in domestic prices via imports (with a one quarter lag). 


\section{Box 2. Chad: Real Effective Exchange Rate Assessment}

Staff examined the appropriateness of the prevailing real exchange rate using the CGER methodologies, adapted to the characteristics of Chad, a low-income oil producer. ${ }^{1}$ The results suggest that the current level of the REER is not substantially misaligned; the medium-term scenario on which the conclusions are based assumes significant fiscal adjustment over time ( $\$ 22)$ to ensure fiscal sustainability:

- Equilibrium Real Exchange Rate Approach. Regressions of the REER on a set of fundamentals suggest that, based on the current values of fundamentals, the REER exceeded its estimated equilibrium value by about 4 percent in 2009 .

- Macroeconomic Balance Approach. Estimations using this approach suggest an overvaluation of the REER of some 6-8 percent, which is the size of the depreciation needed to align the underlying current account balance with its estimated medium-term norm.

- External Sustainability Approach. Estimations using this approach point to an overvaluation of the REER of some 5-8 percent. This is the size of the depreciation needed to close the gap between the underlying current account balance and a benchmark level that would stabilize the net foreign liability position at an assumed medium-term norm.

The results come with caveats in the case of Chad, given the projected depletion of oil revenues and the ensuing challenge of specifying appropriate medium-term norms for the current account balance and the net foreign liability position.

\footnotetext{
${ }^{1}$ For more on the CGER methodologies, see Lee et al (2008), "Exchange Rate Assessments: CGER Methodologies", IMF Occasional Paper 261; and Bems and de Carvalho Filho (2009), "Exchange Rate Assessments: Methodologies for Oil Exporting Countries” IMF Working Paper No. 09/281.
}

\section{Policy Discussions}

17. The Article IV consultation discussions centered on five main themes: (i) measures to address food shortages; (ii) the medium-term macroeconomic outlook; (iii) anchoring fiscal policy in a medium-term framework that recognizes the temporary nature of oil resources; (iv) improving public financial management for transforming oil resources into higher nonoil growth and lower poverty; and (v) fostering non-oil sector growth.

\section{A. Measures to Address Food Shortages}

18. Both short-term measures to address the immediate food shortage and long term action to improve agricultural productivity are needed. As in other Sahel countries, Chad is facing severe food shortages in 2010 in the aftermath of the poor rainfall in 2009. Agricultural production fell by one third in 2009 (\$9). Accordingly, about 2 million people (18 percent of the population) could face severe food shortages during the coming months, unless the shortfall of $80,000-100,000$ tons of food is made up by that time. The government 
has started using its stock of 10,000 tons of food and ordered about 33,000 tons of food, at a cost of CFA 20 billion (about 0.8 percent of non-oil GDP), to be included in the 2010 supplementary budget ( $\$ 24)$. The World Food Program is coordinating the importation of 47,000 tons of food, at an estimated cost of $\$ 65$ million, to be financed by the donor community. The staff welcomed the authorities' prompt reaction to the crisis, while also pointing to the need for further efforts, assisted by donors, to improve agricultural productivity over the medium term.

\section{B. Medium-Term Macroeconomic Outlook}

\section{The macroeconomic outlook is shaped by the expected rebound of agriculture,} the construction of a second oil project, the gradual recovery of oil prices, and the need for fiscal adjustment in response to financing constraints (Text Table 4).

- Non-oil growth will be boosted by the expected rebound of agriculture and major construction projects, including a second oil project (about one third the size of the project initiated in 2003), an oil refinery, and a power plant.

- Inflation should converge toward the CEMAC target of 3 percent in 2011, with improved agricultural production, new roads facilitating trade, and fiscal consolidation.

- The overall balance of payments should strengthen on account of higher oil prices and capital inflows to finance the second oil project.

- The overall fiscal balance is expected to improve owing to the recovery of oil prices in 2010 and to fiscal adjustment responding to financing constraints starting in 2011. While the authorities have secured the financing to increase spending in 2010 ( $\mid 24)$, a severe fiscal adjustment is looming in 2011 as, absent a surge in oil prices, there are few financing options ( $\mid 21)$.

- While agreeing with staff on the outlook for 2010, the authorities had not yet formed a view on the outer years.

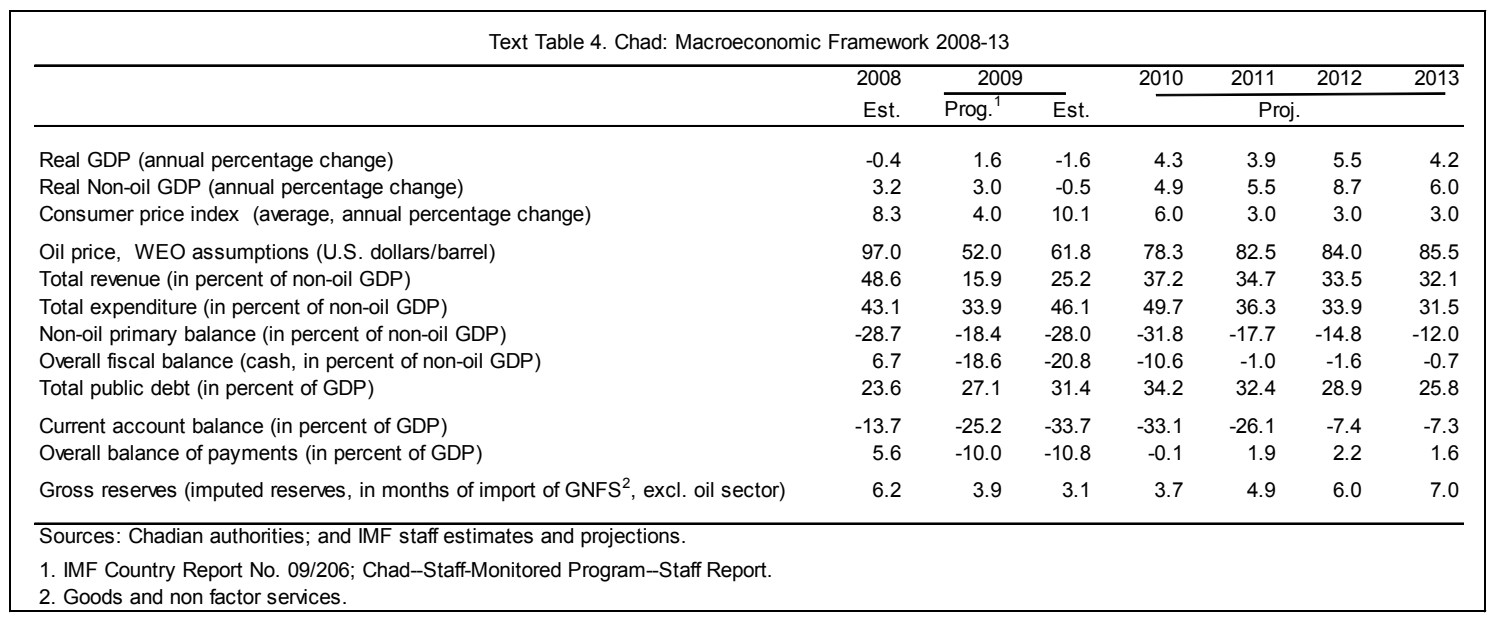




\section{Anchoring Fiscal Policy in a Medium-Term Framework}

\section{Fiscal policy in the medium-term}

20. For staff, the central feature of Chad's medium- and long-term macroeconomic outlook is the steady decline of annual oil production during the next twenty years. The annual production of the Doba oil field reached its peak in 2005 and is projected to decrease steadily over the next twenty years and become negligible after 2030 (Figure 1). The decline of oil production will be reflected in falling government revenue (Figure 6). Improvements in non-oil tax policy and revenue collection could attenuate the reduction of oil revenue. However, even after taking feasible improvements into account, total government revenue in Chad would still decline from about 37 percent of non-oil GDP in 2010 to about 20 percent in 2030 (based on current oil price assumptions in the WEO). ${ }^{8}$

\section{The absence of fiscal adjustment in response to the decline of oil production} would lead to a sharp increase in debt, were it financeable. In fact, financing options to avoid fiscal adjustment are limited as a result of the near-exhaustion of oil savings and central bank statutory advances ( $\$ 11)$, the underdevelopment of financial markets in the CEMAC, and the absence of sustained external financing for budget support ( $₫ 5$ ). However, if the authorities were able to secure financing to maintain the current level of spending, the resulting debt path would increase steeply, leading to an unmanageable debt and debt-service burden (Box 3).

\section{To address the trend decline of annual oil production, staff proposed}

undertaking a fiscal adjustment strategy based on achieving a steady improvement over time in the non-oil primary balance (NOPB). A prudent fiscal policy that reduces the nonoil primary deficit to a sustainable level over the medium term would allow both the transformation of oil revenue into a higher level of physical and human capital than before the oil era and the accumulation of savings to support consumption levels in the post-oil period. In order to build up meaningful savings by the end of the oil period, the NOPB would need to reach its sustainable level ( $₫ 3$ ) by about 2020 (Figure 7). Fiscal consolidation need not come at the expense of development priorities if spending focuses on priority areas.

\footnotetext{
${ }^{8}$ The successful exploitation of the second oil field under construction ( $\left.\uparrow 19\right)$ would not significantly alter the downward path of oil revenue, as this oil field is only about one third of the size of the Doba oil field. Moreover, a positive impact on public finances of this oil field hinges on the resolution of outstanding questions, such as the access of oil production to export markets and the profitability of the oil refinery.
} 
Box 3. Chad: Debt Sustainability Analysis ${ }^{1}$

Present value of Debt-to-GDP ratio

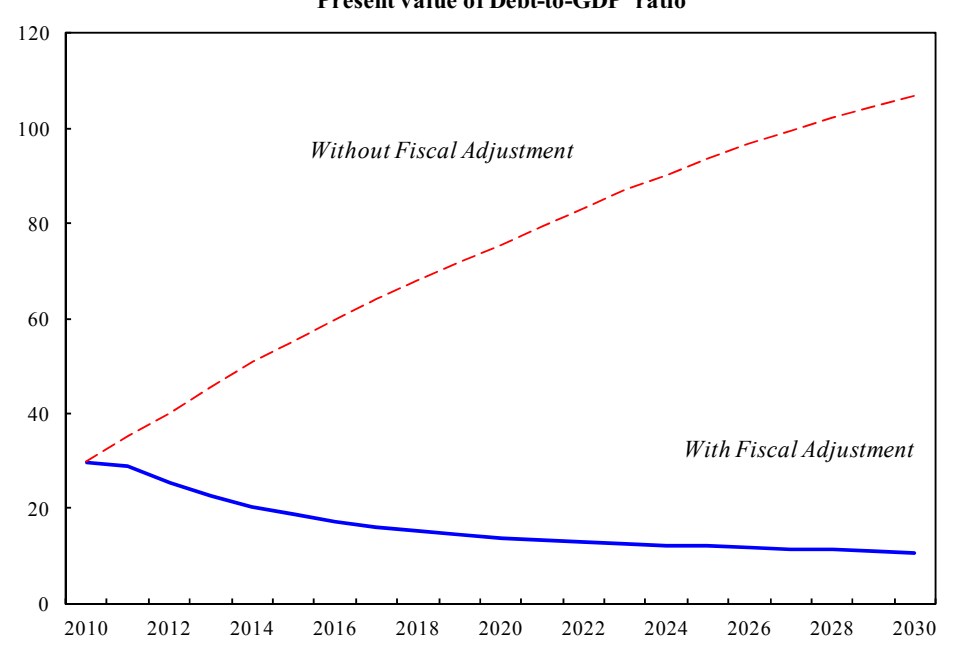

The updated DSA points to the urgent need for fiscal consolidation and a cautious approach to incurring new debt. If the current spending level were maintained and additional financing could be secured, the resulting debt path would increase steeply, leading to an unmanageable debt and debt-service burden ("Without Fiscal Adjustment"). If domestically financed spending were adjusted in parallel with oil revenue declines, the resulting debt path would be sustainable ("With Fiscal Adjustment").

While remaining moderate owing to the still low level of debt, Chad's debt vulnerabilities have increased since last year's DSA because total public debt is increasing steeply. Total debt is rising fast (from 24 percent of GDP in 2008 to 34 percent of GDP in 2010) on account of two large external loans and credit from the regional central bank. The authorities have secured a $\$ 300$ million loan with a grant element of 15 percent from an official creditor to finance the budget. They have also guaranteed a loan of about $€ 232$ million on commercial terms to finance the government's share ( 40 percent) of a new oil refinery, now under construction, to be operated in a joint venture with a Chinese oil company.

${ }^{1}$ Chad_-Joint Fund-Bank Debt Sustainability Analysis under the Debt Sustainability Framework for LowIncome Countries (forthcoming). 
Figure 6. Chad: Total revenue, oil revenue, and non-oil revenue, 2000-31

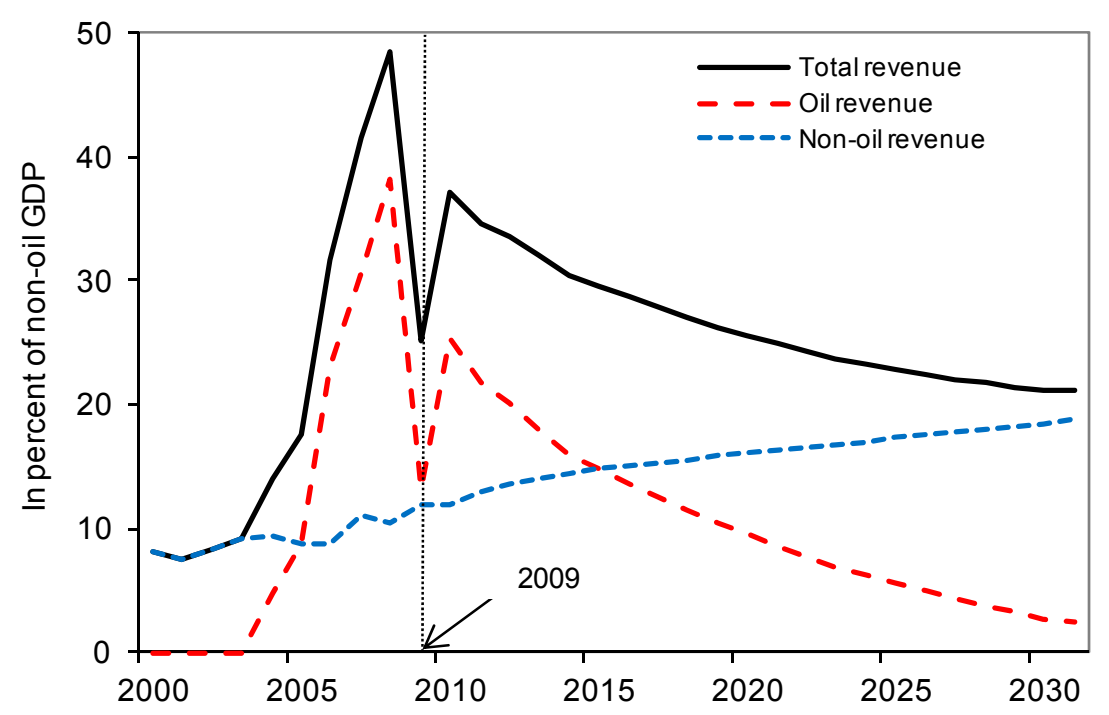

Source: Chadian authorities; and staff estimates and projections.

Figure 7. Chad: Non-Oil Primary Balance (NOPB), 2000-20

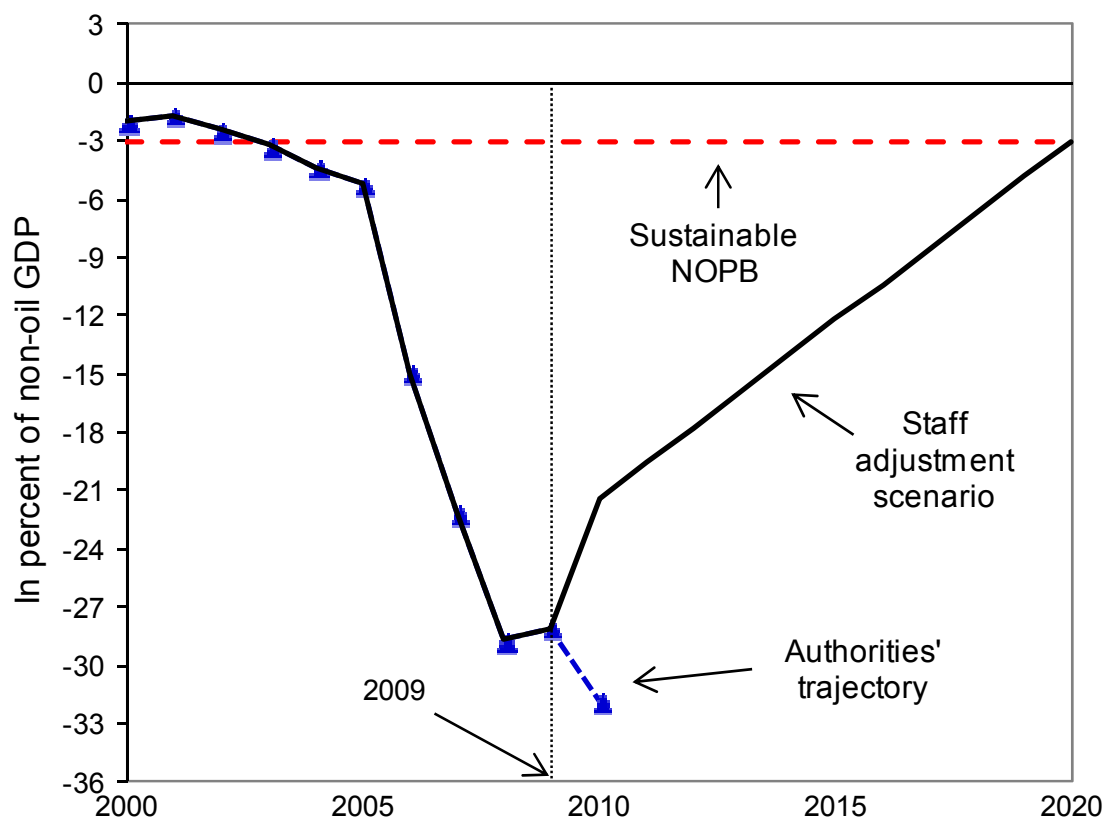

Source: Chadian authorities; and staff estimates and projections. 
23. While the authorities acknowledged that the fiscal situation had become very tight, they expressed more optimism about the medium-term outlook and argued that higher investment levels were needed to facilitate longer term development. In light of the sharp reduction of government deposits at the BEAC and the near-exhaustion of their ceiling on statutory advances from BEAC (Tables 3-4), the authorities noted that their shortterm financial situation had become very tight. They attributed most of the deterioration in their fiscal position to the security outlays needed to defeat rebel attacks in 2008-09. Going forward, they expected that the improvement in the security situation ( $₫ 1$ ) would boost nonoil economic activity and non-oil revenue and allow a decline of security spending. They also noted that higher-than-expected oil prices or the discovery of new oil fields or other natural resources would improve the outlook. Finally, they argued that higher investment levels were necessary to meet the country's pressing development needs.

Fiscal policy in 2010

24. The authorities and staff agreed that a supplementary budget was needed to respond to under-funded priority outlays, but held different views on the scale of the revision that was warranted.

- The 2010 budget approved by parliament in December 2009 envisaged a major reduction of the non-oil primary deficit from the unsustainable highs of 2008-09 and a significant improvement in the composition of expenditure (Text Table 5 and Tables 3-4).

- The authorities now face significant spending pressures owing to food shortages ( $\mid 18)$, the upcoming elections, ongoing investments, arrears, and other liabilities. Hence, staff and the authorities agreed on the need to prepare a supplementary budget that would accommodate some of the spending pressures.

- However views differed on the level of total spending. While the authorities and staff agreed on the need to accommodate spending pressure in an amount of about 4 percent of non-oil GDP, the authorities felt it necessary to add further spending in an amount of about 11 percent of non-oil GDP, much of it for security purposes.

- While the authorities' plan could be financed by using the full amount of a loan in an amount of $\$ 300$ million secured from an official creditor (Box 3), staff recommended a tighter fiscal stance in order to reduce the non-oil primary deficit without further delay and to limit the scale of the adjustment needed in 2011. 


\begin{tabular}{|c|c|c|c|c|c|}
\hline \multicolumn{6}{|c|}{$\begin{array}{l}\text { Text Table 5. Chad - Fiscal Operations of the Central Government, 2009-11 } \\
\text { (In percent of non-oil GDP, unless otherwise indicated) }\end{array}$} \\
\hline & \multirow{2}{*}{$\begin{array}{c}2009 \\
\text { Est. }\end{array}$} & \multicolumn{3}{|c|}{2010} & \multirow{2}{*}{$\begin{array}{l}2011 \\
\text { Proj. }\end{array}$} \\
\hline & & Budget & Staff & Auth. & \\
\hline Revenue & 25.2 & 31.4 & 37.2 & 37.2 & 34.7 \\
\hline Oil revenue & 13.2 & 19.2 & 25.3 & 25.3 & 21.8 \\
\hline Non-oil revenue & 11.9 & 12.2 & 12.0 & 12.0 & 12.9 \\
\hline Expenditure & 46.1 & 34.7 & 39.0 & 49.7 & 36.3 \\
\hline Current expenditure & 29.6 & 22.3 & 24.7 & 33.5 & 22.6 \\
\hline Investment expenditure & 16.5 & 12.5 & 14.3 & 16.2 & 13.8 \\
\hline Domestically financed & 11.3 & 9.1 & 9.3 & 11.1 & 8.7 \\
\hline Foreign financed & 5.2 & 3.4 & 5.1 & 5.1 & 5.1 \\
\hline Non-oil primary balance ${ }^{1}$ & -28.0 & -18.6 & -21.4 & -31.8 & -17.7 \\
\hline Overall balance (excl. grants, cash) & -20.8 & -3.8 & -4.5 & -10.6 & -1.0 \\
\hline Domestic financing & 15.4 & -2.2 & -0.7 & 1.0 & -2.7 \\
\hline Foreign financing & 5.5 & 6.0 & 5.1 & 9.6 & 3.7 \\
\hline \multicolumn{6}{|l|}{ Memorandum item: } \\
\hline Total military spending & 14.5 & 7.9 & 8.0 & 15.2 & 9.9 \\
\hline Priority spending (in percent of tot. exp. excl. int.) ${ }^{2}$ & 34.5 & 44.2 & 38.3 & 37.9 & $\ldots$. \\
\hline Deposits in banks (mostly BEAC) & 3.8 & 1.0 & 1.3 & 1.0 & 1.0 \\
\hline $\begin{array}{l}\text { Sources: Chadian authorities; and IMF staff estimat } \\
\text { 1. Defined in Table 3, footnote } 3 . \\
\text { 2. Defined in Table 3, footnote } 5 .\end{array}$ & & & & & \\
\hline
\end{tabular}

\section{Improving Public Financial Management for Transforming Oil Resources into Higher Non-Oil Growth and Lower Poverty}

\section{The staff and the authorities agreed that across-the-board improvement in public financial management is needed. As to specific reforms:}

- The exemplary transparency of the interim petroleum revenue management mechanism in tracking oil revenue should be preserved once the authorities start receiving royalties in kind rather than cash.

- Actions underway to implement the Extractive Industry Transparency Initiative will help to maintain revenue transparency.

- Non-oil tax revenue performance needs to be improved by expanding nascent reforms at the tax administration and simplifying the tax and customs codes.

- Budget preparation needs to be enhanced by aligning the budget more closely with the PRS, improving investment preparation and monitoring, and providing sufficient resources for current spending in health and education to make operational the many schools, hospitals, and health centers already built or under construction. 
- Budget execution needs to be tightened by adhering to normal budget procedures, using competitive bidding, and regularly monitoring budget execution.

\section{E. Fostering Non-Oil Sector Growth}

26. Improving the environment for private business is essential for medium-term growth prospects. The authorities noted, and staff agreed, that the ongoing improvement in the security situation, if maintained, would provide a vital boost to business confidence. Staff called for government leadership and early actions in the following priority areas:

- Improving the judiciary is essential for developing the financial sector and the non-oil economy at large. As an illustration, private sector representatives noted that companies keep their bank deposits at a minimum out of fear of asset seizures flowing from frivolous law suits.

- Close cooperation with the regional bank supervisor is needed to restructure a sizable bank that faces solvency problems. Non-performing loans need to be written off and the bank needs to be recapitalized or wound down in an orderly manner.

- Reforming the energy and cotton sector companies is overdue. As a first step, the accounts of these and other state-owned companies should be audited to lay the ground for reforms and published to foster transparency and accountability.

\section{RELATIONS WITH THE FUND}

27. The policy response to key issues raised in recent Article IV consultations has been limited. Little progress has been made in improving the sustainability of fiscal policy, PFM, or the quality of public spending.

28. Performance under the 2009 SMP was mixed. The authorities took some measures to resume normal budget procedures under the SMP (Table 11), but sizeable spending overruns on security and public investment pushed the SMP well off track ( $₫ 11$ and Table 10) and the planned review of the SMP was not completed.

29. The authorities and staff discussed the possibility of a new SMP that would cover most of 2010, but agreement could not be reached on the appropriate level of budgetary outlays for the year ( $\mid 24)$. Staff noted that a SMP covering 2011 could be discussed next year: key objectives of a SMP would be to ensure that budgetary outlays remained within targets and that all non-security outlays were executed in accordance with budget procedures. 
30. Serious data shortcomings continue to hamper surveillance. Shortcomings are most serious in public finance data, the balance of payments, and national accounts. ${ }^{9}$ The authorities have been working with the Central African Regional Technical Assistance Center and the Fund's Statistics Department to improve statistics in these areas. The staff recommended allocating more resources to statistical collection and analysis.

\section{Staff Appraisal}

31. The global financial crisis affected Chad mainly through the decline in oil prices. The fiscal position deteriorated sharply in 2009 as the government increased spending levels in the face of a fall-off in oil revenues by depleting its oil savings and borrowing from the central bank.

32. Prompt reaction to the pressing food shortage needs to be complemented by measures to increase agriculture productivity. The authorities have been quick to mobilize internal and external resources to import food. In the medium term, measures to improve agricultural yields are needed.

33. The current fiscal stance is unsustainable. In 2009, expenditure exceeded (by large margins) the expenditure ceilings under both the initial budget approved in December 2008 and the supplementary budget approved in August 2009. Oil savings have vanished and public debt has increased significantly since 2008. Two large non-concessional loans have increased debt vulnerabilities.

34. Fiscal policy needs to be tightened within a medium-term framework that factors in the trend decline of oil production over the next 20 years. The non-oil primary deficit should be steadily reduced, while focusing spending on priority areas, to allow accumulation of some savings before oil depletion. Absent a fiscal adjustment, the debt would rapidly reach unsustainable levels.

35. In 2010, the authorities should adopt a supplementary budget that substantially reduces the non-oil primary deficit while accommodating priority spending. This would limit the scale of the adjustment needed in 2011.

36. Improving public financial management is key to transforming oil resources into higher non-oil sector growth and lower poverty. Preserving the exemplary transparency of oil revenue, expanding recent improvements in tax administration, aligning spending with the PRS, and improving public investment planning and procurement are among the main priorities.

\footnotetext{
${ }^{9}$ See Chad-Staff Report for the 2010 Article IV Consultation-Informational Annex (forthcoming), pp. 9-12, for more details.
} 
37. Acceleration of non-oil growth will require substantial improvements in the business climate. Priority measures include strengthening the functioning of the judicial system, deepening the financial sector while addressing problem banks, and reforming the state-owned cotton and utility companies.

38. Staff recommends that the next Article IV consultation be held on the 12-month cycle. 
Table 1. Chad: Selected Economic and Financial Indicators, 2008-13

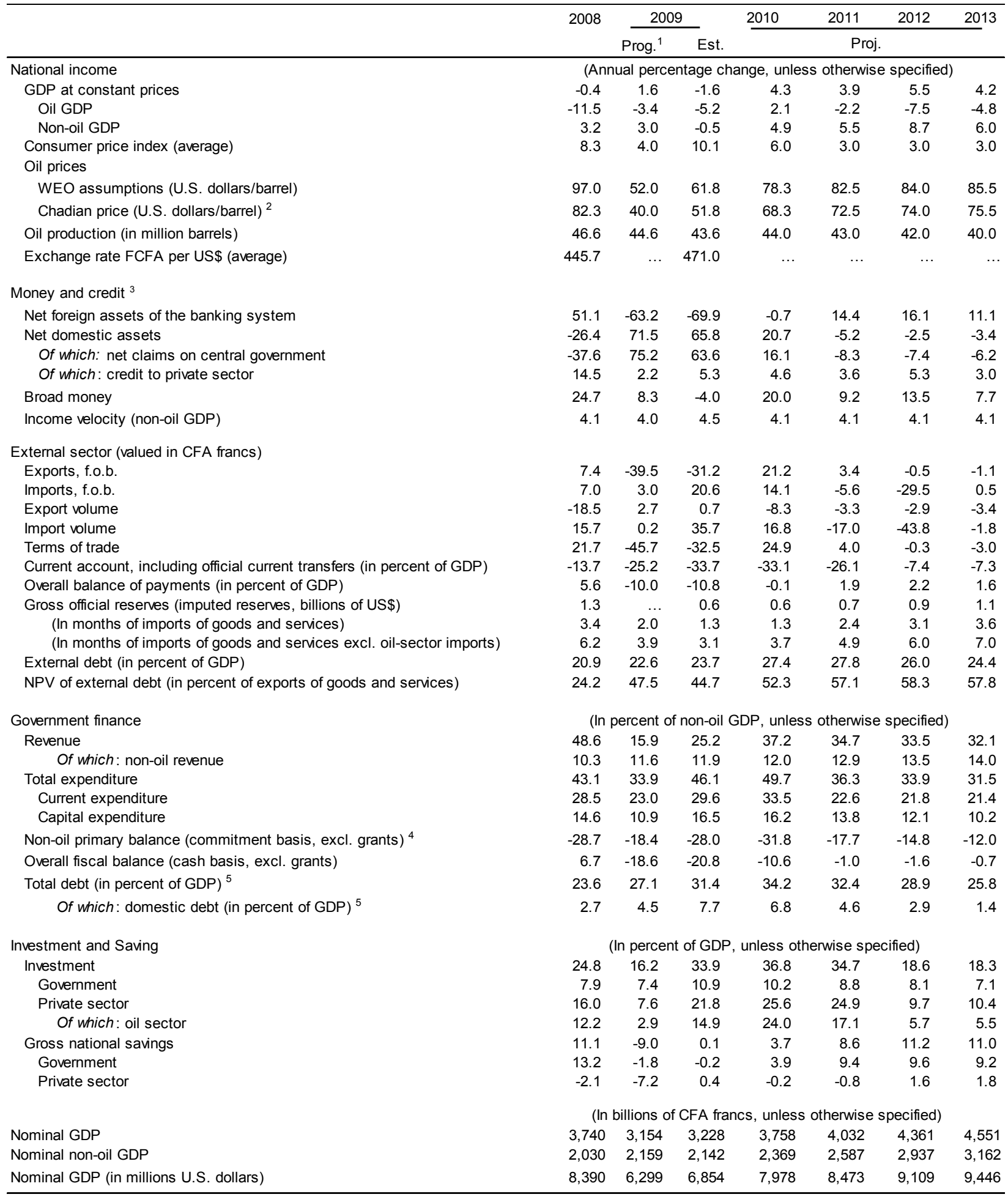

Sources: Chadian authorities; and IMF staff estimates and projections.

1. IMF Country Report No. 09/206; Chad--Staff-Monitored Program--Staff Report.

2. Chadian oil price is WEO price minus quality discount.

3. Changes as a percent of broad money stock at beginning of period.

4. Defined as the total revenue excluding grants and oil revenue,

minus total expenditure excluding interest payments and foreign-financed investment.

5. Central government. 
Table 2. Chad: Real Sector and Demand Indicators, 2008-13

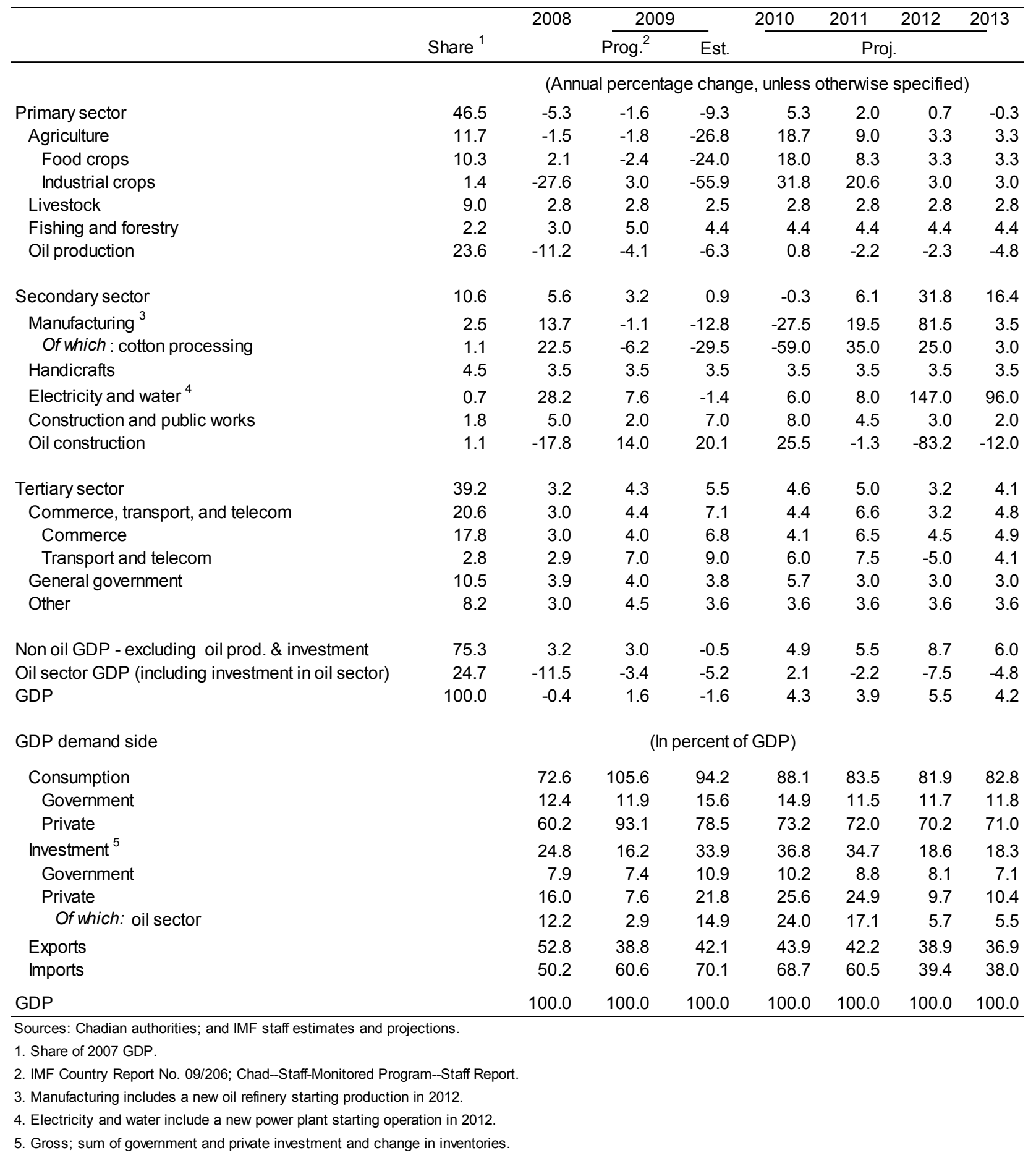


Table 3. Chad: Fiscal Operations of the Central Government, 2008-13 (in billions of CFA francs, unless otherwise indicated)

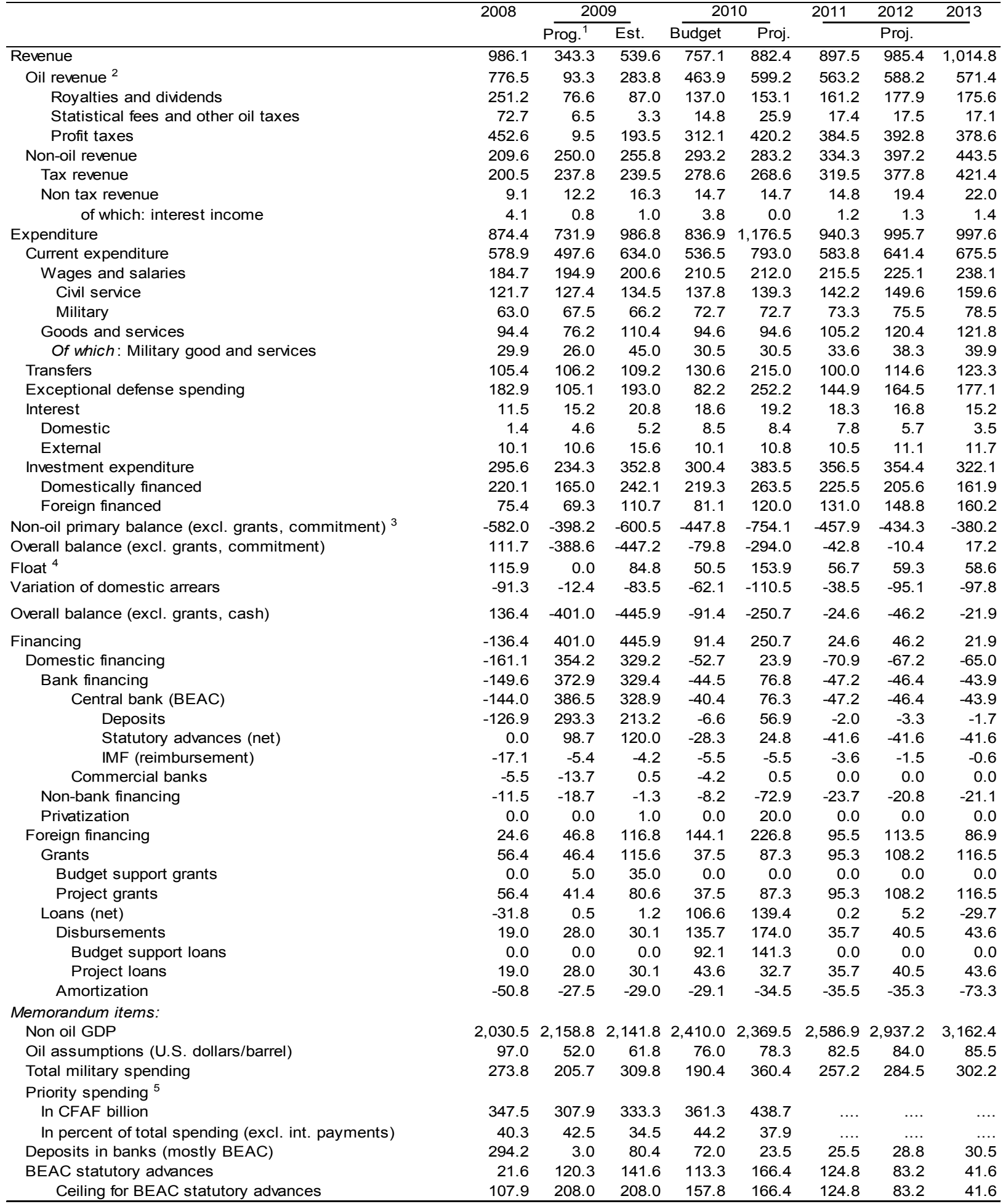

Sources: Chadian authorities; and IMF staff estimates and projections.

1. IMF Country Report No. 09/206; Chad--Staff-Monitored Program--Staff Report. Revised budget.

2. Oil export price based on WEO assumptions minus quality discount.

3. Defined as the total revenue excluding grants and oil revenue, minus total expenditure excluding interest payments and foreign-financed investment.

4. Difference between committed and paid expenditure.

5. Spending in infrastructure, education, health, social programs, agriculture, cattle breeding, justice, and environment. 
Table 4. Chad: Fiscal Operations of the Central Government, 2008-13 (in percent of non-oil GDP, unless otherwise indicated)

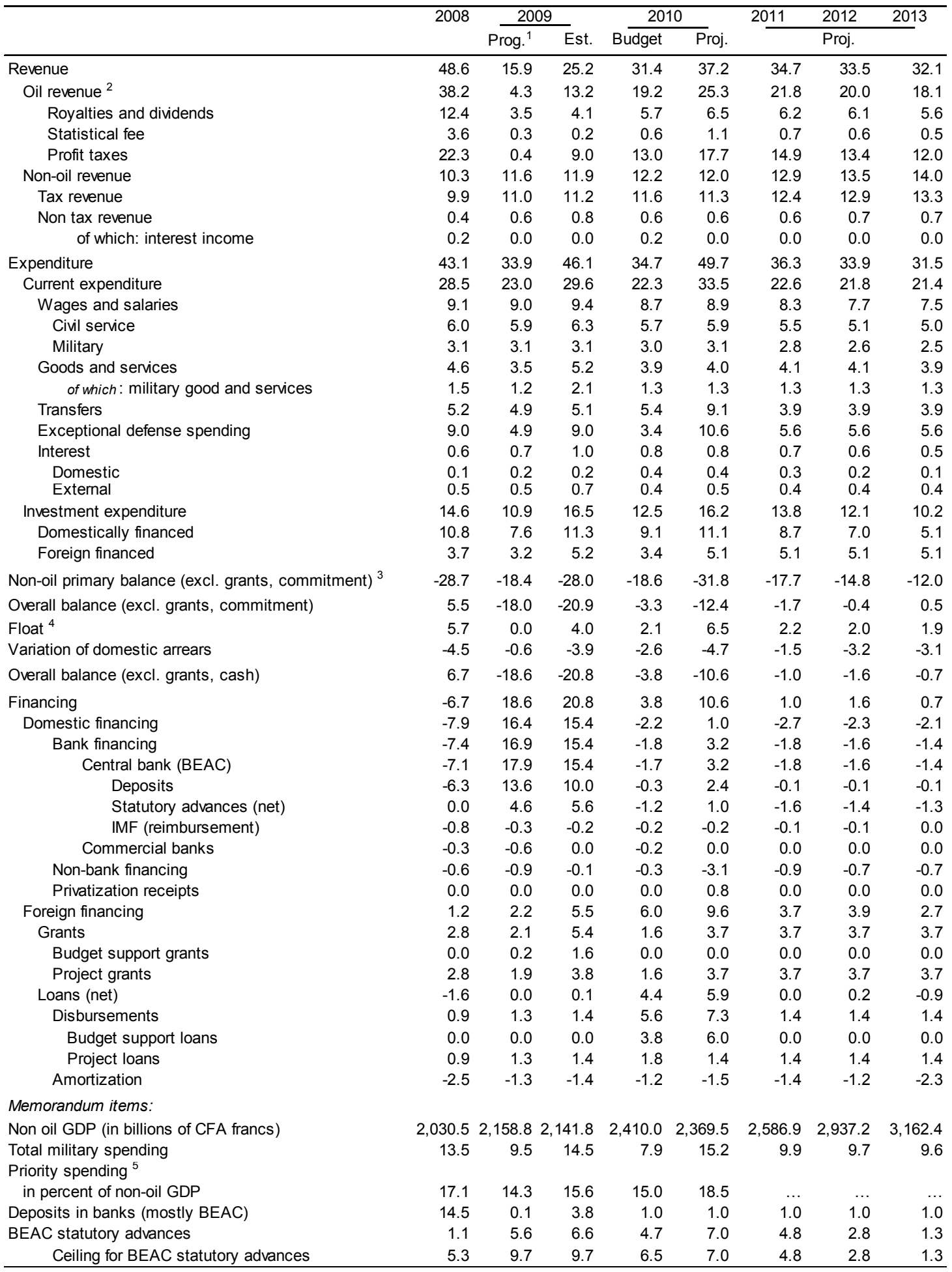

Sources: Chadian authorities; and IMF staff estimates and projections.

1. IMF Country Report No. 09/206; Chad--Staff-Monitored Program--Staff Report.

2. Oil export price based on WEO assumptions minus quality discount.

3. Defined as the total revenue excluding grants and oil revenue, minus total expenditure excluding interest payments and foreign-financed investment.

4. Difference between committed and paid expenditure.

5. Spending in infrastructure, education, health, social programs, agriculture, cattle breeding, justice, and environment. 
Table 5. Chad: Balance of Payments, 2008-13 (in billions of CFA francs, unless otherwise indicated)

\begin{tabular}{|c|c|c|c|c|c|c|c|}
\hline \multirow{3}{*}{ Current account, incl. official current transfers } & \multirow{3}{*}{$\begin{array}{r}2008 \\
-513.2\end{array}$} & \multicolumn{2}{|c|}{2009} & \multirow{2}{*}{2010} & \multirow{2}{*}{$\frac{2011}{\text { Pro }}$} & \multirow[t]{2}{*}{2012} & \multirow[t]{2}{*}{2013} \\
\hline & & Prog. ${ }^{1}$ & Est. & & & & \\
\hline & & -795.1 & $-1,088.5$ & $-1,244.2$ & $-1,052.5$ & -324.8 & -332.5 \\
\hline Trade balance, incl. oil sector & $1,010.0$ & 172.8 & 80.2 & 109.1 & 372.8 & 876.1 & 829.5 \\
\hline Exports, f.o.b. of which: & $1,894.9$ & $1,143.9$ & $1,279.1$ & $1,565.0$ & $1,617.9$ & $1,606.7$ & $1,585.9$ \\
\hline Cotton exports & 31.6 & 27.5 & 17.9 & 10.2 & 12.4 & 13.5 & 14.0 \\
\hline Cattle exports & 131.9 & 136.1 & 144.3 & 143.5 & 152.0 & 160.9 & 170.4 \\
\hline Oil exports & $1,701.7$ & 894.3 & $1,082.9$ & $1,373.9$ & $1,412.4$ & $1,387.0$ & $1,351.7$ \\
\hline Imports, f.o.b. & -884.9 & -971.1 & $-1,198.9$ & $-1,456.0$ & $-1,245.1$ & -730.6 & -756.4 \\
\hline Net Services & -912.5 & -859.8 & -984.5 & $-1,043.6$ & $-1,107.6$ & -899.8 & -879.6 \\
\hline Net Services, excl oil & -223.3 & -288.0 & -281.9 & -241.4 & -244.1 & -186.2 & -201.1 \\
\hline Net Factor Income & -744.2 & -278.6 & -337.4 & -422.6 & -432.2 & -420.1 & -405.7 \\
\hline Net Factor Income, excl oil & 16.2 & 17.0 & 16.8 & 19.0 & 31.1 & 24.2 & 26.5 \\
\hline Current transfers (net) & 133.5 & 170.4 & 153.2 & 112.9 & 114.5 & 119.0 & 123.2 \\
\hline Official (net) & 86.1 & 97.9 & 87.3 & 58.1 & 63.6 & 72.5 & 78.3 \\
\hline Private (net) & 47.4 & 72.5 & 65.9 & 54.8 & 50.9 & 46.4 & 45.0 \\
\hline Financial and capital account & 668.5 & 480.4 & 739.6 & $1,240.2$ & $1,127.5$ & 421.0 & 407.2 \\
\hline Capital transfers & 56.4 & 41.4 & 80.6 & 87.3 & 95.3 & 108.2 & 116.5 \\
\hline FDI & 536.7 & 368.6 & 559.6 & 875.5 & 884.4 & 241.2 & 251.3 \\
\hline Other medium \& long term investment & 60.3 & 70.5 & 96.3 & 277.4 & 147.8 & 71.5 & 39.4 \\
\hline Public Sector & -31.8 & 0.5 & 1.2 & 139.4 & 0.2 & 5.2 & -29.7 \\
\hline Private Sector & 92.1 & 70.0 & 95.1 & 138.0 & 147.6 & 66.3 & 69.1 \\
\hline Short-term capital & -39.1 & 0.0 & 3.1 & 0.0 & 0.0 & 0.0 & 0.0 \\
\hline Errors and omissions & -54.2 & 0.0 & 0.0 & 0.0 & 0.0 & 0.0 & 0.0 \\
\hline Overall balance & 209.5 & -314.7 & -348.9 & -4.0 & 75.0 & 96.2 & 74.7 \\
\hline Financing & -209.5 & 314.7 & 348.9 & 4.0 & -75.0 & -96.2 & -74.7 \\
\hline Net Foreign Assets (BEAC) & -209.5 & 314.7 & 348.9 & 4.0 & -75.0 & -96.2 & -74.7 \\
\hline Residual Financing Need & 0.0 & 0.0 & 0.0 & 0.0 & 0.0 & 0.0 & 0.0 \\
\hline \multicolumn{8}{|l|}{ Memorandum items: } \\
\hline Gross official reserves (imputed reserves, billions of US $\$$ ) & 1.3 & $\ldots$ & 0.6 & 0.6 & 0.7 & 0.9 & 1.1 \\
\hline (In percent of broad money) & 125.4 & $\ldots$ & 57.9 & 47.7 & 56.9 & 64.2 & 70.0 \\
\hline (In months of imports of goods and services) & 3.4 & 2.0 & 1.3 & 1.3 & 2.4 & 3.1 & 3.6 \\
\hline (In months of imports of g. and s. excl. oil-sector imports) & 6.2 & 3.9 & 3.1 & 3.7 & 4.9 & 6.0 & 7.0 \\
\hline CEMAC gross official reserves (billions of US $\$$ ) & 15.4 & & 14.5 & & & & \\
\hline (In percent of broad money) & 134.5 & & 111.6 & & & & \\
\hline (In months of imports of goods and services) & 3.2 & & 2.9 & & & & \\
\hline
\end{tabular}

Sources: Chadian authorities; and IMF staff estimates and projections.

1. IMF Country Report No. 09/206; Chad--Staff-Monitored Program--Staff Report. 
Table 6. Chad: Monetary Survey, 2008-13

(in billions of CFA francs)

\begin{tabular}{|c|c|c|c|c|c|c|c|}
\hline & \multirow[t]{2}{*}{2008} & \multicolumn{2}{|c|}{2009} & 2010 & 2011 & 2012 & 2013 \\
\hline & & Prog. ${ }^{1}$ & Est. & \multicolumn{4}{|c|}{ Proj. } \\
\hline Net foreign assets & 622.4 & 308.6 & 275.8 & 272.5 & 354.6 & 454.7 & 533.4 \\
\hline Central bank & 613.9 & 299.2 & 264.9 & 261.0 & 336.0 & 432.2 & 506.9 \\
\hline Commercial banks & 8.5 & 9.4 & 10.9 & 11.6 & 18.7 & 22.6 & 26.5 \\
\hline Net domestic assets & -126.3 & 228.6 & 200.2 & 298.8 & 269.1 & 253.4 & 229.0 \\
\hline Domestic credit & -74.0 & 309.8 & 267.8 & 366.3 & 339.8 & 326.8 & 304.4 \\
\hline Claims on the government (net) & -252.0 & 121.0 & 63.7 & 140.5 & 93.3 & 46.9 & 3.0 \\
\hline Treasury (net) & -225.2 & 162.7 & 87.9 & 164.6 & 117.4 & 71.0 & 27.1 \\
\hline Banking sector & -244.4 & 147.5 & 74.1 & 154.4 & 109.6 & 64.4 & 21.6 \\
\hline Central bank & -242.7 & 149.2 & 89.6 & 169.4 & 124.6 & 79.4 & 36.6 \\
\hline Commercial banks & -2.3 & -2.3 & -16.2 & -15.7 & -15.7 & -15.7 & -15.7 \\
\hline CCP & 0.6 & 0.6 & 0.7 & 0.7 & 0.7 & 0.7 & 0.7 \\
\hline Fund position & 19.2 & 15.2 & 13.7 & 10.2 & 7.8 & 6.6 & 5.5 \\
\hline Other non-treasury & -26.7 & -41.7 & -24.1 & -24.1 & -24.1 & -24.1 & -24.1 \\
\hline Credit to the economy & 178.0 & 188.9 & 204.1 & 225.8 & 246.5 & 279.9 & 301.4 \\
\hline Other items (net) & -52.3 & -81.2 & -67.6 & -67.5 & -70.7 & -73.4 & -75.3 \\
\hline Money and quasi money & 496.1 & 537.1 & 476.0 & 571.3 & 623.7 & 708.1 & 762.4 \\
\hline Currency outside banks & 313.1 & 286.0 & 280.1 & 298.5 & 319.6 & 355.8 & 375.4 \\
\hline Demand deposits & 153.1 & 199.8 & 162.9 & 215.4 & 238.2 & 274.0 & 298.8 \\
\hline Time and savings deposits & 29.9 & 51.3 & 33.1 & 57.4 & 65.8 & 78.3 & 88.1 \\
\hline \multicolumn{8}{|l|}{ Memorandum items: } \\
\hline Broad money (annual percentage change) & 24.7 & 8.3 & -4.0 & 20.0 & 9.2 & 13.5 & 7.7 \\
\hline Velocity (non-oil GDP) & 4.1 & 4.0 & 4.5 & 4.1 & 4.1 & 4.1 & 4.1 \\
\hline Velocity (total GDP) & 7.5 & 5.9 & 6.8 & 6.6 & 6.5 & 6.2 & 6.0 \\
\hline Net claims of the banking system on the government (flows) & -149.7 & 372.9 & $315.7^{2}$ & 76.8 & -47.2 & -46.4 & -43.9 \\
\hline
\end{tabular}

Sources: Chadian authorities; and IMF staff estimates and projections.

1. IMF Country Report No. 09/206; Chad--Staff-Monitored Program--Staff Report.

2. The CFAF 14.2 billion discrepancy with the corresponding number in the fiscal accounts (Table 3, Bank financing, 329.4) corresponds to an accumulation of government deposits in commercial banks not recorded in the fiscal operations of the central government. 
Table 7. Chad: Financial Soundness Indicators, 2003-09 (Ratios in Percent)

\begin{tabular}{|c|c|c|c|c|c|c|c|}
\hline & 2003 & 2004 & 2005 & 2006 & 2007 & 2008 & 2009 \\
\hline & \multicolumn{7}{|c|}{ Solvency } \\
\hline \multirow[t]{2}{*}{ Capital/assets (unweighted) ${ }^{1}$} & 9.4 & 11.0 & 8.3 & 8.3 & 9.7 & 13.5 & 16.5 \\
\hline & \multicolumn{7}{|c|}{ Asset quality, profitability, and liquidity } \\
\hline Gross Non Performing Loans/Gross banking loans & 17.4 & 15.5 & 12.9 & 12.4 & 11.6 & 8.7 & 10.9 \\
\hline Net Non Performing Loans ${ }^{2} /$ Gross banking loans & 3.9 & 2.0 & 2.1 & 2.3 & 1.5 & 2.4 & 3.4 \\
\hline Return on assets & 2.3 & 0.0 & 2.0 & 1.5 & 1.9 & 2.6 & 1.5 \\
\hline Return on equity & 24.8 & 0.2 & 24.5 & 18.7 & 13.0 & 18.9 & 9.3 \\
\hline Liquid assets/total assets ${ }^{3}$ & 23.2 & 28.5 & 26.3 & 38.3 & 44.6 & 30.9 & 28.7 \\
\hline \multirow[t]{2}{*}{ Liquid assets/demand deposits } & 65.7 & 74.8 & 75.8 & 78.9 & 108.2 & 72.0 & 70.1 \\
\hline & \multicolumn{7}{|c|}{ Banks' rating (in number of banks) } \\
\hline Solid or Good & 3 & 2 & 2 & 4 & 6 & 4 & 4 \\
\hline Fragile & 2 & 3 & 4 & 2 & 0 & 1 & 1 \\
\hline Critical & 0 & 0 & 0 & 0 & 0 & 1 & 1 \\
\hline Not rated & 1 & 2 & 1 & 1 & 1 & 1 & 2 \\
\hline Number of banks & 6 & 7 & 7 & 7 & 7 & 7 & 8 \\
\hline
\end{tabular}

Sources: BEAC/COBAC.

1. Tier 1 capital.

2. Net of provisions on non performing loans.

3. Core liquid assets. 
Table 8. Chad: Selected Economic and Financial Indicators, 2008-15

\begin{tabular}{|c|c|c|c|c|c|c|c|c|}
\hline & 2008 & 2009 & 2010 & 2011 & 2012 & 2013 & 2014 & 2015 \\
\hline & \multicolumn{7}{|c|}{ Proj. } & \\
\hline National income & \multicolumn{8}{|c|}{ (Annual percentage change, unless otherwise specified) } \\
\hline GDP at constant prices & -0.4 & -1.6 & 4.3 & 3.9 & 5.5 & 4.2 & 2.6 & 2.7 \\
\hline Oil GDP & -11.5 & -5.2 & 2.1 & -2.2 & -7.5 & -4.8 & -4.0 & -4.2 \\
\hline Non-oil GDP & 3.2 & -0.5 & 4.9 & 5.5 & 8.7 & 6.0 & 3.9 & 3.9 \\
\hline Consumer price index (average) & 8.3 & 10.1 & 6.0 & 3.0 & 3.0 & 3.0 & 3.0 & 3.0 \\
\hline \multicolumn{9}{|l|}{ Oil prices } \\
\hline WEO assumptions (U.S. dollars/barrel) & 97.0 & 61.8 & 78.3 & 82.5 & 84.0 & 85.5 & 87.0 & 88.8 \\
\hline Chadian price (U.S. dollars/barrel) ${ }^{1}$ & 82.3 & 51.8 & 68.3 & 72.5 & 74.0 & 75.5 & 77.0 & 78.8 \\
\hline Oil production (in million barrels) & 46.6 & 43.6 & 44.0 & 43.0 & 42.0 & 40.0 & 38.4 & 36.9 \\
\hline Exchange rate FCFA per US\$ (average) & 445.7 & 471.0 & $\ldots$ & $\ldots$ & $\ldots$ & $\ldots$ & $\ldots$ & $\ldots$ \\
\hline \multicolumn{9}{|l|}{ Money and credit ${ }^{2}$} \\
\hline Net foreign assets of the banking system & 51.1 & -69.9 & -0.7 & 14.4 & 16.1 & 11.1 & 16.1 & 13.3 \\
\hline Net domestic assets & -26.4 & 65.8 & 20.7 & -5.2 & -2.5 & -3.4 & -9.8 & 0.4 \\
\hline Of which: net claims on central government & -37.6 & 63.6 & 16.1 & -8.3 & -7.4 & -6.2 & -6.6 & -1.9 \\
\hline Of which: credit to private sector & 14.5 & 5.3 & 4.6 & 3.6 & 5.3 & 3.0 & 2.5 & 2.5 \\
\hline Broad money & 24.7 & -4.0 & 20.0 & 9.2 & 13.5 & 7.7 & 6.4 & 6.4 \\
\hline Income velocity (non-oil GDP) & 4.1 & 4.5 & 4.1 & 4.1 & 4.1 & 4.1 & 4.1 & 4.1 \\
\hline \multicolumn{9}{|l|}{ External sector (valued in CFA francs) } \\
\hline Exports, f.o.b. & 7.4 & -31.2 & 21.2 & 3.4 & -0.5 & -1.1 & -0.2 & -0.2 \\
\hline Imports, f.o.b. & 7.0 & 20.6 & 14.1 & -5.6 & -29.5 & 0.5 & -0.9 & 2.9 \\
\hline Export volume & -18.5 & 0.7 & -8.3 & -3.3 & -2.9 & -3.4 & -2.5 & -2.7 \\
\hline Import volume & 15.7 & 35.7 & 16.8 & -17.0 & -43.8 & -1.8 & -4.5 & 3.9 \\
\hline Terms of trade & 21.7 & -32.5 & 24.9 & 4.0 & -0.3 & -3.0 & -1.1 & -1.0 \\
\hline Current account, including official current transfers (in percent of GDP) & -13.7 & -33.7 & -33.1 & -26.1 & -7.4 & -7.3 & -6.5 & -7.0 \\
\hline Overall balance of payments (in percent of GDP) & 5.6 & -10.8 & -0.1 & 1.9 & 2.2 & 1.6 & 2.5 & 2.1 \\
\hline Gross official reserves (imputed reserves, billions of US $\$$ ) & 1.3 & 0.6 & 0.6 & 0.7 & 0.9 & 1.1 & 1.3 & 1.6 \\
\hline (In months of imports of goods and services) & 3.4 & 1.3 & 1.3 & 2.4 & 3.1 & 3.6 & 4.3 & 5.0 \\
\hline (In months of imports of goods and services excl. oil-sector imports) & 6.2 & 3.1 & 3.7 & 4.9 & 6.0 & 7.0 & 8.0 & 9.0 \\
\hline External debt (in percent of GDP) & 20.9 & 23.7 & 27.4 & 27.8 & 26.0 & 24.4 & 23.0 & 21.6 \\
\hline NPV of external debt (in percent of exports of goods and services) & 24.2 & 44.7 & 52.3 & 57.1 & 58.3 & 57.8 & 56.7 & 55.5 \\
\hline Government finance & \multicolumn{8}{|c|}{ (In percent of non-oil GDP, unless otherwise specified) } \\
\hline Revenue & 48.6 & 25.2 & 37.2 & 34.7 & 33.5 & 32.1 & 30.4 & 29.6 \\
\hline Of which: non-oil revenue & 10.3 & 11.9 & 12.0 & 12.9 & 13.5 & 14.0 & 14.4 & 14.8 \\
\hline Total expenditure & 43.1 & 46.1 & 49.7 & 36.3 & 33.9 & 31.5 & 30.9 & 32.5 \\
\hline Current expenditure & 28.5 & 29.6 & 33.5 & 22.6 & 21.8 & 21.4 & 19.9 & 20.3 \\
\hline Capital expenditure & 14.6 & 16.5 & 16.2 & 13.8 & 12.1 & 10.2 & 11.1 & 12.2 \\
\hline Non-oil primary balance (commitment basis, excl. grants) ${ }^{3}$ & -28.7 & -28.0 & -31.8 & -17.7 & -14.8 & -12.0 & -11.1 & -12.4 \\
\hline Overall fiscal balance (cash basis, excl. grants) & 6.7 & -20.8 & -10.6 & -1.0 & -1.6 & -0.7 & -1.6 & -2.8 \\
\hline Total debt (in percent of GDP) ${ }^{4}$ & 23.6 & 31.4 & 34.2 & 32.4 & 28.9 & 25.8 & 23.2 & 21.6 \\
\hline Investment and Saving & \multicolumn{8}{|c|}{ (In percent of GDP, unless otherwise specified) } \\
\hline Gross investment & 24.8 & 33.9 & 36.8 & 34.7 & 18.6 & 18.3 & 17.7 & 16.5 \\
\hline Government & 7.9 & 10.9 & 10.2 & 8.8 & 8.1 & 7.1 & 7.9 & 8.9 \\
\hline Private sector & 16.0 & 21.8 & 25.6 & 24.9 & 9.7 & 10.4 & 9.0 & 6.9 \\
\hline Of which: oil sector & 12.2 & 14.9 & 24.0 & 17.1 & 5.7 & 5.5 & 5.2 & 5.0 \\
\hline Gross national savings & 11.1 & 0.1 & 3.7 & 8.6 & 11.2 & 11.0 & 11.1 & 9.4 \\
\hline Government & 13.2 & -0.2 & 3.9 & 9.4 & 9.6 & 9.2 & 9.2 & 8.5 \\
\hline \multirow[t]{2}{*}{ Private sector } & -2.1 & 0.4 & -0.2 & -0.8 & 1.6 & 1.8 & 1.9 & 0.9 \\
\hline & \multicolumn{8}{|c|}{ (In billions of CFA francs, unless otherwise specified) } \\
\hline Nominal GDP & 3,740 & 3,228 & 3,758 & 4,032 & 4,361 & 4,551 & 4,729 & 4,922 \\
\hline Nominal non-oil GDP & 2,030 & 2,142 & 2,369 & 2,587 & 2,937 & 3,162 & 3,363 & 3,578 \\
\hline Nominal GDP (in millions U.S. dollars) & 8,390 & 6,854 & 7,978 & 8,473 & 9,109 & 9,446 & 9,753 & 10,088 \\
\hline
\end{tabular}

Sources: Chadian authorities; and IMF staff estimates and projections.

1. Chadian oil price is WEO price minus quality discount.

2. Changes as a percent of broad money stock at beginning of period.

3. Defined as the total revenue excluding grants and oil revenue, minus total expenditure excluding interest payments and foreign-financed investment.

4. Central government. 
Table 9. Chad: Millennium Development Goals, 1990-2008

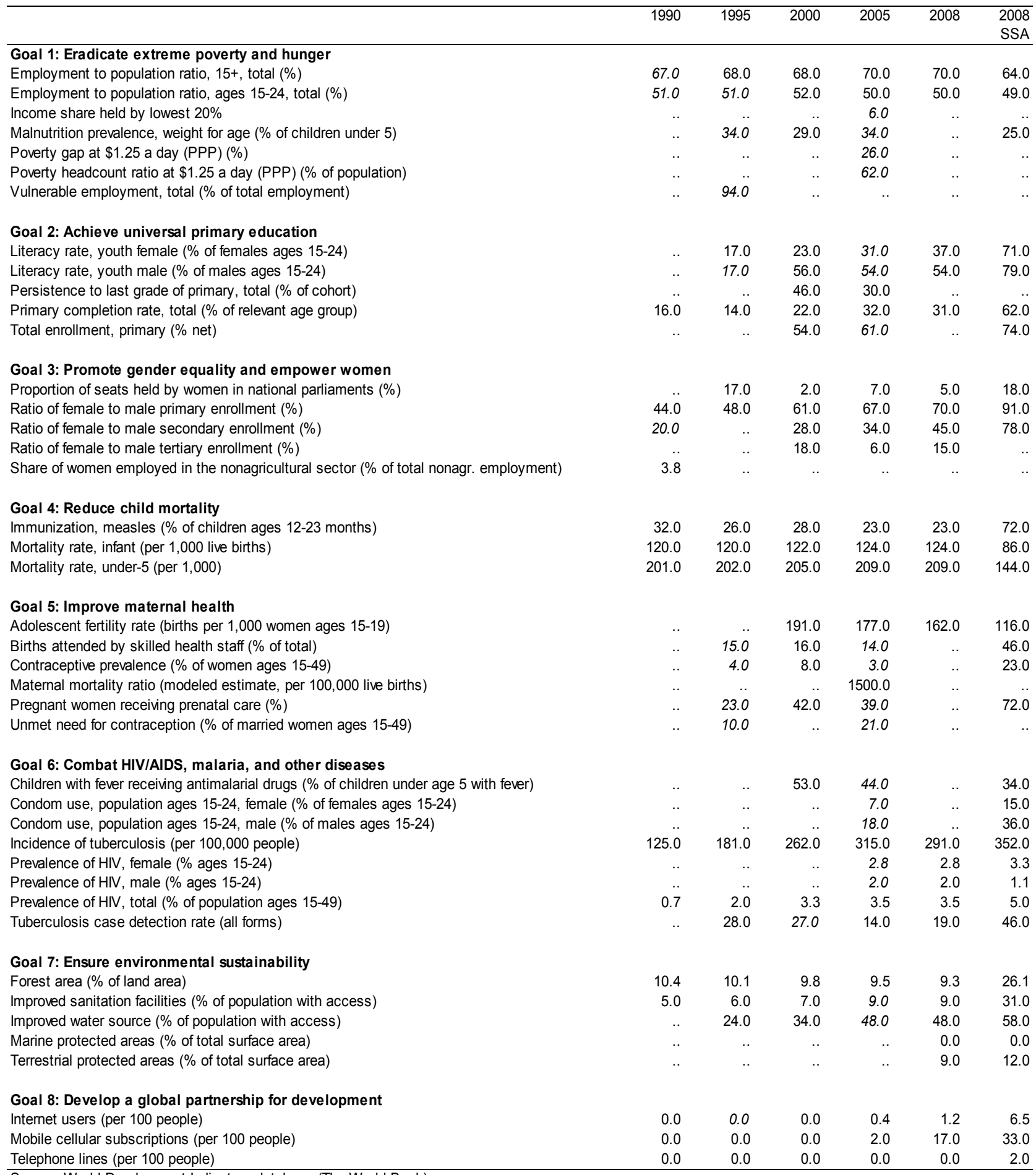

Source: World Development Indicators database (The World Bank)

${ }^{1}$ Figures in italics refer to periods other than those specified. 
Table 10. Chad: Indicative Targets for the Period April 1 to October 31, 2009 and Projections for the Period Beyond (in billions of CFA francs; cumulative changes from the beginning of the calendar year, unless otherwise indicated)

\begin{tabular}{|c|c|c|c|c|c|c|c|c|c|c|}
\hline & \multicolumn{4}{|c|}{ 30-Jun } & \multicolumn{4}{|c|}{ 30-Sep } & \multicolumn{2}{|r|}{ 31-Dec } \\
\hline & Prog. $^{2}$ & Prog. Adj. ${ }^{3}$ & Est. & Status & Prog. $^{2}$ & Prog. Adj. ${ }^{3}$ & Est. & Status & Proj. $^{2}$ & Est. \\
\hline Non-oil primary fiscal balance, floor & -236.8 & $\ldots$ & -309.9 & Not met & -292.8 & $\ldots$ & -374.8 & Not met & -398.2 & -600.5 \\
\hline $\begin{array}{l}\text { Net claims of the banking system on the government, ceiling } \\
\text { Civilian expenditures executed through exceptional budget procedure ("DAO"), ceiling } \\
\text { Accumulation of domestic payment arrears by the government, ceiling }{ }^{4}\end{array}$ & $\begin{array}{c}189.0 \\
70.0 \\
0.0\end{array}$ & $\begin{array}{c}178.3 \\
\ldots \\
\ldots\end{array}$ & $\begin{array}{c}208.6 \\
68.7 \\
0.0\end{array}$ & $\begin{array}{l}\text { Not met } \\
\text { Met } \\
\text { Met }\end{array}$ & $\begin{array}{c}236.6 \\
80.0 \\
0.0\end{array}$ & $\begin{array}{c}145.5 \\
\ldots \\
\ldots\end{array}$ & $\begin{array}{c}242.3 \\
78.3 \\
0.0\end{array}$ & $\begin{array}{l}\text { Not met } \\
\text { Met } \\
\text { Met }\end{array}$ & $\begin{array}{c}372.9 \\
90.0 \\
0.0\end{array}$ & $\begin{array}{c}329.4 \\
91.3 \\
7.9\end{array}$ \\
\hline Accumulation of external payment arrears by the government, ceiling ${ }^{4}$ & 0.0 & $\ldots$ & 0.0 & Met & 0.0 & $\ldots$ & 0.0 & Met & 0.0 & 0.0 \\
\hline $\begin{array}{l}\text { Government's contracting or guaranteeing of new nonconcessional external debt, except } \\
\text { normal trade financing with a maturity of up to one year, ceiling }{ }^{4}\end{array}$ & 0.0 & $\cdots$ & 0.0 & Met & 0.0 & $\ldots$ & $€ 232$ million $^{5}$ & Not met & 0.0 & $\begin{array}{l}€ 232 \text { million }^{5} \text { and } \\
\$ 300 \text { million }^{6}\end{array}$ \\
\hline \multicolumn{11}{|l|}{ Memorandum items: } \\
\hline Total oil revenue & 87.4 & & 98.2 & & 89.2 & & 180.3 & & 93.3 & 283.8 \\
\hline Corporate Income Tax (IS) & 7.5 & & 18.3 & & 8.5 & & 94.9 & & 9.5 & 193.5 \\
\hline Royalties and dividends & 76.6 & & 76.6 & & 76.6 & & 82.2 & & 76.6 & 87.0 \\
\hline Other oil revenue & 3.3 & & 3.3 & & 4.1 & & 3.3 & & 7.2 & 3.3 \\
\hline
\end{tabular}

Sources: Chadian authorities; IMF staff estimates and projections

1. Indicative Targets are defined in more detail in the technical memorandum of understanding (TMU) of June 22, 2009.

2. IMF Country Report No. 09/206; Chad-Staff Monitored Program.

3. As per the adjustment clause in the TMU.

4. Continuous

5. $€ 232$ million loan guaranteed, with a LIBOR plus 3 percent interest rate, a 5-year grace period, and a 10 year maturity, for the construction of an oil refinery.

6. US $\$ 300$ million loan contracted with an official creditor, with a 2 percent interest rate supported by the lender, a 2.5-year grace period, and a 6 -year maturity. 
Table 11. Chad: Prior Action and Structural Benchmarks for the Staff-Monitored Program April-

October 2009

\begin{tabular}{lcc}
\hline \multicolumn{1}{c}{ Measure } & Deadline & Status \\
\hline $\begin{array}{l}\text { Prior action for submitting the program for } \\
\text { Management approval }\end{array}$ & Met \\
$\begin{array}{l}\text { Submission to Parliament of a draft } 2009 \\
\text { supplementary budget consistent with the } \\
\text { macroeconomic framework agreed with Fund staff. }\end{array}$ & \\
$\begin{array}{l}\text { Structural benchmark } \\
\text { Adoption of a Communication by the Council of }\end{array}$ & June 30, 2009 \\
$\begin{array}{l}\text { Ministers recalling the need to respect budgetary } \\
\text { procedures, including that no investment project can } \\
\text { be launched by the government without the prior } \\
\text { existence of a budget appropriation. }\end{array}$ & \\
$\begin{array}{l}\text { Publication of a circular limiting the categories of } \\
\text { expenditure that can be executed using the } \\
\text { exceptional budgetary procedure bypassing the } \\
\text { normal expenditure chain called dépenses avant } \\
\text { ordonnancement (DAO). }\end{array}$ & \\
$\begin{array}{l}\text { Submission to Parliament of a draft } 2010 \text { budget } \\
\text { consistent with the macroeconomic framework } \\
\text { agreed with Fund staff. }\end{array}$ & \\
\hline
\end{tabular}


INTERNATIONAL MONETARY FUND

CHAD

\section{Staff Report for the 2010 Article IV Consultation Informational Annex}

Prepared by the African Department

(In consultation with other departments)

Approved by Seán Nolan and Dhaneshwar Ghura

June 1,2010

- $\quad$ Relations with the Fund. Describes financial and technical assistance by the IMF and provides information on the safeguards assessment and exchange system.

- Joint Management Action Plan (JMAP). Describes the priorities and main activities of the World Bank Group and areas of cooperation with the IMF in their work with the Chadian authorities.

- $\quad$ Statistical Issues. Assesses the quality of statistical data. Data provision has serious shortcomings that significantly hamper surveillance. 


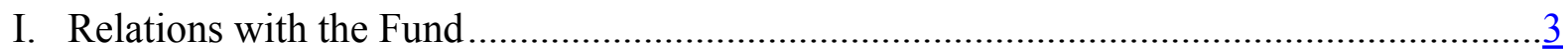

II. Relations with the Bank ...................................................................................

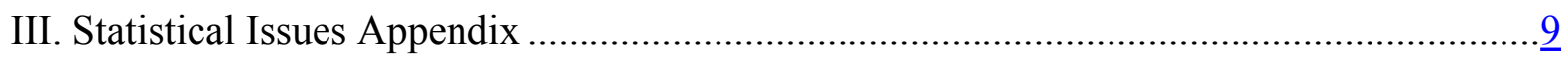




\section{Chad: Relations with the Fund}

(as of April 30, 2010)

I. Membership Status: Joined: July 10, 1963

Article VIII

II. General Resources Account:

SDR Million

Quota

56.00

\%Quota

Fund holdings of currency

55.72

100.00

Reserve Position

0.28

99.50

Holdings Exchange Rate

0.50

III. SDR Department:

SDR Million

\%Allocation

Net cumulative allocation

53.62

100.00

Holdings

2.80

5.22

IV. Outstanding Purchases and Loans:

ECF Arrangements

SDR Million

15.58

\%Quota

27.82

V. Latest Financial Arrangements:

Type Date of Expiration Amount Approved Amount Drawn

\begin{tabular}{|c|c|c|c|c|}
\hline & Arrangement & Date & (SDK Million) & (SDK MH1IIOn) \\
\hline $\mathrm{ECF}^{\mathbf{1 /}}$ & Feb 16, 2005 & May 31, 2008 & 25.20 & 4.20 \\
\hline $\mathrm{ECF}^{\mathbf{1 /}}$ & Jan 07, 2000 & Jan 06, 2004 & 47.60 & 42.40 \\
\hline $\mathrm{ECF}^{\mathbf{1 /}}$ & Sep 01, 1995 & Apr 30, 1999 & 49.56 & 49.56 \\
\hline
\end{tabular}

${ }^{1 /}$ Formerly PRGF.

\section{Projected Payments to Fund 2/}

(SDR Million; based on existing use of resources and present holdings of SDRs):

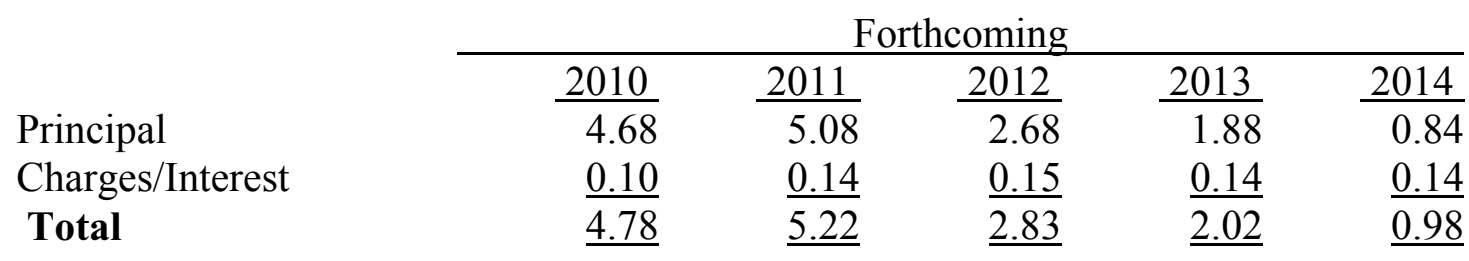

${ }^{2 /}$ When a member has overdue financial obligations outstanding for more than three months, the amount of such arrears will be shown in this section. 
VII. Implementation of HIPC Initiative:

I. Commitment of HIPC assistance

Enhanced

Decision point date

Framework

Assistance committed

by all creditors (US\$ Million) ${ }^{1 /}$

May 2001

Of which: IMF assistance (US\$ million)

170.00

18.00

(SDR equivalent in millions)

14.25

Completion point date

Floating

II. Disbursement of IMF assistance (SDR Million)

Assistance disbursed to the member

8.55

Interim assistance

8.55

Completion point balance

Additional disbursement of interest income ${ }^{2 /}$

Total disbursements

\footnotetext{
${ }^{1 /}$ Assistance committed under the original framework is expressed in net present value (NPV) terms at the completion point, and assistance committed under the enhanced framework is expressed in NPV terms at the decision point. Hence these two amounts cannot be added.

${ }^{2 /}$ Under the enhanced framework, an additional disbursement is made at the completion point corresponding to interest income earned on the amount committed at the decision point but not disbursed during the interim period.
}

\section{Safeguards Assessments}

The Bank of the Central African States (BEAC) is the regional central bank of the Central African States. The most recent safeguards assessment of the BEAC was completed on July 6, 2009. The findings of this assessment indicate that implementation of previous safeguards recommendations on financial reporting, internal audit, and internal control has been limited, and that the changing risk profile of the BEAC foreign exchange holdings requires further actions to strengthen safeguards at the BEAC. Subsequent to revelation of Paris office fraud, a series of initial measures and longer term safeguard measures were agreed between IMF and BEAC in order to continue with country programs. In December 2009, BEAC adopted an action plan with the aim of reforming its own governance, and strengthening key safeguards. A number of special audits are being conducted as well as part of this action plan. There have been delays in conducting the audits and implementing the action plan. 


\section{Exchange Rate Arrangement}

The exchange system common to all members of the BEAC has been free of restrictions on payments and transfers for current international transactions. The BEAC common currency is the CFA franc, which was formerly pegged to the French franc. Repurchase of CFA franc banknotes exported outside the BEAC zone was suspended on August 2, 1993. Effective January 12, 1994, the CFA franc was devalued by 50 percent in foreign currency terms, and the exchange rate was adjusted from F 1 = CFAF 50 to F 1 = CFAF 100. Since January 1, 1999, the CFA franc has been pegged to the euro at the rate of EUR $1=$ CFAF 655.97.

\section{Article IV Consultations}

Chad is on the 12-month cycle. The next Article IV consultation is expected to take place by June 2011 .

\section{Technical Assistance}

$\begin{array}{lll}\text { Department } & \text { Purpose } & \text { Time of Delivery } \\ \text { STA } & \text { Balance of Payments } & \text { May } 2010 \\ \text { MCM (AFRITAC) } & \text { Public debt } & \text { May } 2010 \\ \text { FAD } & \text { Tax policy review } & \text { April-May 2010 } \\ \text { FAD (AFRITAC) } & \text { Tax and custom administration } & \text { March-April 2010 } \\ \text { STA (AFRITAC) } & \text { National accounts } & \text { March 2010 } \\ \text { FAD (AFRITAC) } & \text { Public financial management } & \text { January 2010 } \\ \text { MCM (AFRITAC) } & \text { Public debt } & \text { November 2009 } \\ \text { FAD(AFRITAC) } & \text { Tax and customs administration } & \text { December 2009 } \\ \text { FAD } & \text { Tax and customs administration } & \text { April 2009 } \\ \text { FAD (AFRITAC) } & \text { Treasury management } & \text { March 2009 } \\ \text { STA (AFRITAC) } & \text { Price Statistics } & \text { August, 2008 } \\ \text { STA } & \text { National Accounts } & \text { January-February 2008 } \\ \text { FAD } & \text { Strengthen budget management } & \text { September-October 2007 } \\ \text { FAD (AFRITAC) } & \text { Treasury management } & \text { August 2007 } \\ \text { STA (AFRITAC) } & \text { National accounts } & \text { August 2007 } \\ \text { STA } & \text { Price statistics } & \text { May 2007 } \\ \text { AFRITAC } & \text { Assessment mission } & \text { March 2007 } \\ \text { STA } & \text { Data ROSC } & \text { May 2006 }\end{array}$


XII. Financial Sector Assessment Program (FSAP) Participation, Report on the Observances of Standards and Codes (ROSCs), and Offshore Finance Center (OFC) Assessments

A ROSC Data Module mission visited Chad May 26-June 8, 2005. A joint IMF-World Bank mission conducted a regional FSAP for CEMAC countries during January 30February 9, 2006.

\section{Resident Representative}

Mr. Karangwa has been the Fund Resident Representative in N'djamena since November 2007. 


\section{RELATIONS WITH THE BANK}

\section{THE JMAP BANK-FUND MATRIX \\ (MARCH 2010- JUNE 2011)}

\begin{tabular}{|c|c|c|c|}
\hline Title & Products & $\begin{array}{l}\text { Provisional } \\
\text { Timing of } \\
\text { Missions }\end{array}$ & $\begin{array}{c}\text { Expected } \\
\text { Delivery Date }\end{array}$ \\
\hline
\end{tabular}

\section{A. Mutual Information on Relevant Work Programs}

The World Bank work program in the next 18 months
1. Presentation of an Interim Strategy Note (ISN) to the WB Board.

2. Technical assistance for budget management, including review of budget execution and alignment with PRSP in 2006-09

3. Capacity building in public expenditure management

4. Assistance in strengthening capacities and institutions at the local level under the Local Development Program Support Project, the Urban Development Project, the Education Sector Reform project, and the Second Population and AIDS Project.

5. A regional study on stabilization and recovery for the war-affected border areas between Chad, Sudan/Darfur, and the Central African Republic.

The Fund work program in the next 18 months
1. 2010 Article IV Consultation.

2. Possible staff visit to advise on the elaboration of the 2011 budget.

\section{2011 Article IV Consultation}

\section{Technical Assistance}

1.Tax policy review, including forecasting of taxes paid by the oil sector

2. Public finance management

3. Statistics: external sector (BOP and debt) and national Accounts (update of the base year and $\mathrm{CPI}$ )
June 2010

Ongoing

Ongoing

Ongoing

TBD

March 2010

June 2010: Board conclusion of 2010 Article IV consultation September 2010

September 2010

March 2011

June 2011: Board conclusion of 2011 Article IV consultation

April-May 2010 June 2010

FY2011 FY2011

FY2011 FY2011 


\section{B. Requests for Work Program Inputs}

Fund

request to

1. Comments on the composition of the 2011 budget.

Sept. Sept.

Bank

Bank

2. Assessing consistency of sectoral priority action plans, annual budget, and medium term expenditure frameworks (if available) with the Poverty Reduction Strategy Paper (PRSP)

20102010

Fund
1. Macroeconomic projections and analyses for 2011 and the medium-term

medium-term
2.Information on nonconcessional financing of budget and projects

\section{Agreement on Joint Products and Missions}

Sept. Sept.

$2010 \quad 2010$

Sept,

2010

\begin{tabular}{|c|c|c|c|}
\hline \multirow[t]{3}{*}{$\begin{array}{l}\text { Joint } \\
\text { products }\end{array}$} & 1. Joint Staff Advisory Note on PRSP. & & $\begin{array}{l}\text { May } \\
2010\end{array}$ \\
\hline & 2. Joint Bank-Fund Debt Sustainability Assessment & $\begin{array}{l}\text { March } \\
2010\end{array}$ & $\begin{array}{l}\text { June } \\
2010\end{array}$ \\
\hline & 3. FSAP & FY2011 & FY2011 \\
\hline
\end{tabular}




\section{CHAD-STATISTICAL ISSUES APPENDIX As of May -19, 2010}

\section{Assessment of Data Adequacy for Surveillance}

General: Data has serious shortcomings that significantly hamper surveillance. Shortcomings are most serious in government finance, balance of payments, and national accounts. The 2007 Report on the Observance of Standards and Codes (ROSC) found that the statistical system continues to be weak and to suffer from a shortage of both financial and human resources. More specifically the 2007 ROSC found the following weaknesses: weak source data for national accounts; insufficient coverage of government finance and monetary statistics; inadequate sectoral classification of public entities in all datasets; absence of dissemination of government finance statistics by the Ministry of Economy and Finance; and generally limited data and metadata accessibility. In addition, the country participates in the GDDS since 2002, but its metadata needs to be updated.

National Accounts: The accuracy and reliability of the data are affected by inadequate source data. Also the methodology is not current (SNA 1968). Moreover compilation remains weak due to inadequate funding for the Institut National de la Statistique, des Etudes Economiques et Démographiques (INSEED). In addition, dissemination of data and metadata to the public could be improved by more timely releases and more detailed information.

Price statistics: Despite a new Harmonized Consumer Price Index (IHPC) covering the capital city that replaced the old consumer price index (CPI) in January 2008, significant work is still needed to improve the reliability of the IHPC. The last Central-AFRITAC mission of August 2008 agreed on a short-term program with the INSEED including actions to be undertaken for the improvement of the index.

Government finance statistics: A working group prepares a quarterly Tableau des opérations financières de l'État (TOFE) and monthly debt statistics, mainly for the purpose of the Fund-supported program, which is based on several disparate sources. Only an annual TOFE is disseminated. Chad has not yet been able to resume reporting of detailed data for publication in the Government Finance Statistics Yearbook. Annual fiscal data through 2001 have been reported and are included in the International Finance Statistics (IFS) database. However, significant discrepancies between the deficit and total financing exist.

Monetary statistics: A key shortcoming is insufficient institutional coverage, which is limited to the central bank and commercial banks, whereas microfinance corporations, a growing source of finance in the country, are not covered by the depository corporations' survey. Therefore, monetary and fiscal indicators on net credit to government cannot be easily reconciled, owing to differences in the institutional coverage and grouping of units in general government and the public sector.

In addition, the accuracy of monetary statistics may be affected by large cross-border movements of Banque des Etats de l'Afrique Centrale (BEAC) issued banknotes among Central African Economic and Monetary Community (CEMAC) member countries. About 38 percent of banknotes issued in Chad by the BEAC national directorate circulate in Cameroon, while currency in circulation in Chad includes some 10 percent of banknotes from Cameroon and 5 percent of banknotes from the Central African Republic.

The BEAC has yet to submit test data using the standardized report forms.

Balance of payments: The poor quality of external sector statistics is likely to be related to inadequacies in staffing and in provision of material resources dedicated to compilation. The foreign trade data, compiled by the INSEED on the basis of customs declarations are often unreliable, and suffer from coverage problems; in addition, they are inconsistent with those used in the compilation of national accounts and prevent meaningful analysis. Consequently, they are not fully used by the BEAC in the compilation of balance of payments data. Data on exports are estimated based on data provided by ministries. Even considering the difficulty of 
collecting data on informal border trade between Chad and its neighboring countries, many improvements could be made on such items as imports, cotton and cattle exports, freight, and public transfers. STA has recommended tighter coordination among the CEMAC, INSEED, and other agencies in order to improve the data coverage.

\section{Data Standards and Quality}

Participant in the IMF's General Data Dissemination $\quad$ Data ROSC published on August 2007 System since September 24, 2002.

\section{Reporting to STA (Optional)}

Only international liquidity, monetary statistics, GDP, and prices are currently reported to STA for publication in the International Financial Statistics. 


\section{Chad: Table of Common Indicators Required for Surveillance}

(As of May 19, 2010)

\begin{tabular}{|c|c|c|c|c|c|c|c|}
\hline & \multirow{2}{*}{$\begin{array}{l}\text { Date of latest } \\
\text { observation }\end{array}$} & \multirow[t]{2}{*}{ Date received } & \multirow{2}{*}{$\begin{array}{l}\text { Frequency of } \\
\text { Data }^{7}\end{array}$} & \multirow{2}{*}{$\begin{array}{l}\text { Frequency of } \\
\text { Reporting }^{7}\end{array}$} & \multirow{2}{*}{$\begin{array}{l}\text { Frequency of } \\
\text { Publication }^{7}\end{array}$} & \multicolumn{2}{|l|}{ Memo Items: } \\
\hline & & & & & & $\begin{array}{l}\text { Data Quality - Methodological } \\
\text { soundness }^{8}\end{array}$ & $\begin{array}{l}\text { Data Quality - } \\
\text { Accuracy and } \\
\text { reliability }\end{array}$ \\
\hline Exchange Rates & Daily & Daily & M & M & M & & \\
\hline $\begin{array}{l}\text { International Reserve Assets and Reserve } \\
\text { Liabilities of the Monetary Authorities }{ }^{1}\end{array}$ & $12 / 2009$ & $03 / 2010$ & M & M & M & & \\
\hline Reserve/Base Money & $12 / 2009$ & $03 / 2010$ & M & M & M & \multirow{4}{*}{ LO, LNO, LNO, LO } & \multirow{4}{*}{$\mathrm{LO}, \mathrm{O}, \mathrm{O}, \mathrm{LO}, \mathrm{NA}$} \\
\hline Broad Money & $12 / 2009$ & $03 / 2010$ & M & QM & M & & \\
\hline Central Bank Balance Sheet & $12 / 2009$ & $03 / 2010$ & M & M & M & & \\
\hline $\begin{array}{l}\text { Consolidated Balance Sheet of the Banking } \\
\text { System }\end{array}$ & $12 / 2009$ & $03 / 2010$ & M & M & M & & \\
\hline Interest Rates ${ }^{2}$ & 03/2009 & 04/2009 & MI & QM & M & & \\
\hline Consumer Price Index & $01 / 2010$ & $03 / 2010$ & M & M & M & & \\
\hline $\begin{array}{l}\text { Revenue, Expenditure, Balance and } \\
\text { Composition of Financing }{ }^{3}-\text { General } \\
\text { Government }{ }^{4}\end{array}$ & 03/2009 & 04/2009 & Q & Q & Q & \multirow[t]{2}{*}{ LO, LNO, LO, LO } & \multirow[t]{2}{*}{$\begin{array}{l}\text { O, LO, LO, LO, } \\
\text { NO }\end{array}$} \\
\hline $\begin{array}{l}\text { Revenue, Expenditure, Balance and } \\
\text { Composition of Financing }{ }^{3} \text {-Central } \\
\text { Government }\end{array}$ & 03/2009 & $04 / 2009$ & Q & Q & Q & & \\
\hline $\begin{array}{l}\text { Stocks of Central Government and Central } \\
\text { Government-Guaranteed } \text { Debt }^{5}\end{array}$ & $12 / 2008$ & 04/2009 & Q & Q & Q & & \\
\hline External Current Account Balance & 2007 & 04/2009 & A & A & A & \multirow[b]{2}{*}{$\mathrm{O}, \mathrm{O}, \mathrm{O}, \mathrm{LO}$} & \multirow[b]{2}{*}{$\mathrm{LO}, \mathrm{LO}, \mathrm{O}, \mathrm{O}, \mathrm{O}$} \\
\hline Exports and Imports of Goods and Services & 2007 & $04 / 2009$ & A & A & $\mathrm{A}$ & & \\
\hline GDP/GNP & 2008 & $04 / 2009$ & A & $\mathrm{A}$ & A & LNO, LO, LNO, LO & $\begin{array}{l}\text { LNO, LNO, LNO, } \\
\text { LNO }\end{array}$ \\
\hline
\end{tabular}




\begin{tabular}{|l|l|l|l|l|l|l|}
\hline Gross External Debt & $12 / 2008$ & $04 / 2009$ & Bi-M & Bi-M & Bi-M & \\
\hline International Investment Position $^{6}$ & NA & NA & NA & NA & NA & \\
\hline
\end{tabular}

1/ Any reserve assets that are pledged of otherwise encumbered should be specified separately. Also, data should comprise short-term liabilities linked to a foreign currency but settled by other means as well as the notional values of financial derivatives to pay and to receive foreign currency, including those linked to a foreign currency but settled by other means.

2/ Both market-based and officially-determined, including discount rates, money market rates, rates on treasury bills, notes and bonds.

3/ Foreign, domestic bank, and domestic nonbank financing.

4/ The general government consists of the central government (budgetary funds, extra budgetary funds, and social security funds) and state and local governments.

5/ Including currency and maturity composition.

6/ Includes external gross financial asset and liability positions vis-à-vis nonresidents.

7/ Daily (D); weekly (W); monthly (M); quarterly (Q); annually (A); irregular (I); and not available (NA).

8/ Reflects the assessment provided in the data ROSC (published on August 31, 2007), and based on the findings of the mission that took place during May 28 to June 8 , 2005 for the dataset corresponding to the variable in each row. The assessment indicates whether international standards concerning concepts and definitions, scope, classification/sectorization, and basis for recording are fully observed (O); largely observed (LO); largely not observed (LNO); not observed (NO); and not available (NA).

9/ Same as footnote 8 , except referring to international standards concerning (respectively) source data, assessment of source data, statistical techniques, assessment and validation of intermediate data and statistical outputs, and revision studies. 


\title{
INTERNATIONAL DEVELOPMENT ASSOCIATION AND INTERNATIONAL MONETARY FUND
}

\section{CHAD}

\section{Joint Fund-Bank Debt Sustainability Analysis under the Debt Sustainability Framework for Low-Income Countries}

\author{
Prepared by the staffs of the International Development Association and \\ the International Monetary Fund \\ Approved Sudarshan Gooptu and Sudhir Shetty (IDA) \\ and Seán Nolan and Dhaneshwar Ghura (IMF)
}

June 1,2010

Chad's risk of debt distress remains moderate provided that the authorities adjust the fiscal stance to the decline in oil production. If current policies were continued, the resulting debt path would increase steeply, leading to an unmanageable debt and debt-service burden. Compared to last year's Debt Sustainability Analysis (DSA), Chad's debt vulnerabilities have increased because the authorities have used central bank financing and contracted two large nonconcessional external loans. ${ }^{l}$

\section{BACKGROUND}

\section{A. Recent Developments in Public External Debt}

1. Chad's external debt burden diminished considerably over the past decade thanks to strong oil sector-driven growth and limited borrowing. The nominal stock of external debt declined from 63 percent of GDP in 2001 to 24 percent in 2009 (Text Table 1, Tables 1a and 1b). All of Chad's external debt is public, and the bulk is owed to multilateral creditors, mainly the International Development Association (IDA) and the African Development Bank (AfDB). This includes debts incurred or guaranteed by the central government. The analysis is conducted on a gross basis. Nominal debt levels trended downward as Chad reduced its use of external loans, amortized debt as scheduled, and prepaid IBRD and IDA loans associated with the financing of the Chad-Cameroon Pipeline Project in September 2008.

\footnotetext{
${ }^{1}$ The DSA has been produced jointly by World Bank and Fund staffs in consultation with the staff of the African Development Bank.
} 


\begin{tabular}{|lrrrrrrrrr}
\hline \multicolumn{7}{|c|}{ Text Table 1. Chad: External Debt Stock at Year-End, 2001-09 } \\
(billions of CFA francs)
\end{tabular}

2. Notwithstanding a sharp deterioration of the fiscal position in 2009, external public debt decreased further in nominal terms. The international economic and financial crisis triggered a steep drop in oil revenue and a large increase in the fiscal deficit (to about 21 percent of non-oil GDP). This sharp deterioration of Chad's fiscal position was financed by the depletion of government savings accumulated at the central bank and by the use of central bank statutory advances.

\section{B. Recent Developments in Public Domestic Debt}

3. Chad has a small stock of public domestic debt resulting from the accumulation of past arrears and the recent use of central bank statutory advances. Chad's domestic debt is estimated at about CFA 250 billion (7.7 percent of GDP) at end-2009 (Text Table 2). The public domestic debt includes central bank statutory advances (avances statutaires); treasury arrears (arriérés comptables) from previous budget years; rescheduled debt (dettes conventionnées); legal payment obligations (engagements juridiques); and one small public borrowing. The authorities view settlement of all verified arrears and debts as an opportunity to improve the public sector's credit standing and increase private sector confidence. 


\begin{tabular}{|lrrrrr|}
\hline \multicolumn{5}{|c|}{ Text Table 2. Chad: Public Domestic Debt Stock at Year-End, 2005-09 } \\
(billions of CFA francs) & & & & \\
\hline & 2005 & 2006 & 2007 & 2008 & 2009 \\
\hline Total & 142.1 & 79.2 & 79.1 & 100.6 & 249.7 \\
(Percent of GDP) & 4.6 & 2.4 & 2.4 & 2.7 & 7.7 \\
Central Bank Statutory Advances & 38.3 & - & 17.8 & 21.7 & 141.7 \\
Rescheduled debts & 31.1 & 39.5 & 16.2 & 25.4 & 52.2 \\
Treasury arrears & 34.1 & 24.8 & 26.1 & 41.1 & 25.7 \\
Legal commitments & 38.6 & 14.0 & 18.1 & 11.5 & 29.3 \\
Savings Bonds & - & 0.9 & 0.9 & 0.9 & 0.9 \\
\hline Source: Chadian authorities. & & & & & \\
\hline
\end{tabular}

\section{Status of Implementation of Debt Relief Initiatives}

4. Poor macroeconomic policy performance and limited progress towards other triggers have prevented Chad from reaching the completion point under the Enhanced Heavily Indebted Poor Country (HIPC) Initiative. Chad's inability to meet agreed fiscal targets and to satisfactorily implement a program under the IMF's Poverty Reduction and Growth Facility (PRGF) has been the principal obstacle. The 2005 PRGF expired in 2008 without any reviews being concluded. Subsequent efforts to achieve fiscal stability with the support of Staff-Monitored Programs (SMP) were also derailed by fiscal slippages. Progress towards other completion point triggers ${ }^{2}$ has either been slow, or early gains have been followed by subsequent deterioration. ${ }^{3}$

\section{Meeting the conditions for debt relief under the Enhanced HIPC Initiative and} the Multilateral Debt Relief Initiative (MDRI) would cut external debt in half. MDRI relief would cover the full stock of debt owed to three multilateral creditors (IDA, IMF, and the African Development Fund (AfDF)) that remains after Enhanced HIPC relief on disbursements before end-2004 in the case of IMF and AfDF, and before end-2003 in the case of IDA. In nominal terms, this could total over $\$ 1$ billion and would imply a reduction in debt service of about $\$ 40$ million per year.

\section{Debt Burden Thresholds under the Debt Sustainability Framework}

6. Chad is a weak policy performer for the purpose of debt burden thresholds under the Debt Sustainability Framework (DSF). Chad's rating on the World Bank's

${ }^{2}$ For a description of completion point triggers, see Chad, Decision Point Document for the Enhanced Heavily Indebted Poor Countries (HIPC) Initiative, May 4, 2001, pp. 29-31.

${ }^{3}$ Heavily Indebted Poor Countries (HIPC) Initiative and Multilateral Debt Relief Initiative (MDRI) - Status of Implementation 2009. Table 2B, p.32. 
Country Policy and Institutional Assessment (CPIA) is low (2.62 on average for 2006-08 on a scale from 1 to 6 ) and declining (Chad's CPIA declined from 2.88 in 2005 to 2.53 in 2008). ${ }^{4}$ The corresponding thresholds are shown in Text Table 3.

\begin{tabular}{|lr|}
\hline $\begin{array}{l}\text { Text Table 3. External Public Debt Burden Thresholds for "Weak } \\
\text { Policy Performers" under the Debt Sustainability Framework }\end{array}$ \\
\hline Present value of external debt in percent of: \\
GDP & 30 \\
Exports & 100 \\
Revenue & 200 \\
& \\
External debt service in percent of: & 15 \\
Exports & 25 \\
Revenue
\end{tabular}

\section{BaSeline Scenario Underlying the DebT Sustainability Analysis}

7. The central feature of Chad's medium- and long-term macroeconomic outlook is the steady decline of annual oil production foreseen over the next twenty years. Production at the Doba oil field started in 2003, reached its peak of 61 million barrels in 2004, with annual output set to decline steadily to a negligible level beyond 2030. Long-term oil export projections are based on this gradual depletion of the Doba field. Due to its quality, Chad's oil sells at a discount, usually of \$10-15 per barrel relative to the international reference price, reflecting a quality discount and transport cost. For the medium term (to 2015) the Chadian price is assumed to grow at the same rate as assumed in the IMF's World Economic Outlook (WEO); for the longer term (2015 to 2030), at the growth rate of the International Energy Agency's (IEA) reference price. Work has started to exploit a second oil field, about one third the size of the Doba oil field. Modest output from the second field is intended to supply the joint-venture refinery in N'djamena, once the refinery and the needed pipeline are completed in 2012. This second oil field is projected to reduce Chad's imports of refined petroleum products, but not to increase oil exports or fiscal revenues.

8. The oil production decline will necessitate a fiscal adjustment because financing options are limited. Dwindling oil revenues will drive a steady decline of total government revenue (from 37 percent of non-oil GDP in 2010 to 20 percent in 2030). The successful

\footnotetext{
${ }^{4}$ For CPIA methodology and results, see IDA Country Performance ratings 2008.
} 


\section{Box 1. Baseline Macroeconomic Assumptions}

The primary driver of real GDP growth in the baseline scenario is the steady decline of annual oil production over the next twenty years ( $\$ 7)$. Non-oil growth should increase above its long term average in the short term owing to the construction of the second oil field, an oil refinery, a new power plant, and the impact of road construction on internal trade. After that, non-oil growth is expected to return to its pre-oil era trend growth.

Inflation moderates rapidly in the short term to stabilize at a level consistent with the CEMAC convergence criterion of maximum 3 percent per year (Table $1 b$ ).

The current account remains in significant deficit until the new pipeline and refinery are complete and operational in 2012, at which time construction-related and refined petroleum product imports drop significantly. Similarly, strong FDI, associated with the refinery and other investment projects, slows upon their completion in 2012 ( $\$ 7$, Table 1a).

The fiscal outlook is dominated by dwindling oil revenues and limited financing options. The authorities adjust primarily by restraining expenditure, but also with tax policy and administration reforms that increase non-oil revenue (\$8).

External financing consists of project loans from official multilateral and bilateral creditors to finance public investment, but at less concessional terms over time, and stable official grants and other net transfers ( $₫ 10$ and Table 1a).

exploitation of the second oil field and refinery under construction would not significantly alter the downward path of revenue, as this oil field is only about one third of the size of the Doba oil field, and the profitability of the projects hinges on yet to be resolved logistical and other issues. It is assumed that the authorities will adjust to this permanent decline of oil revenue because their financing options are limited: savings at the central bank are practically exhausted; the central bank's statutory advance ceilings are declining gradually; the central bank window will close in 2014; and sustained external finance has been identified only for project loans. The fiscal adjustment is assumed to be accomplished primarily by restraining expenditure, but also by increasing non-oil revenue, through tax policy and revenue administration reforms.

\section{In the short term, debt ratios will increase significantly owing to two large non-} concessional external loans. These loans will increase external public debt from 24 percent of GDP in 2009 to 28 percent in 2011 (Table 1a). An official creditor has agreed to lend the Government of Chad $\$ 300$ million (3.6 percent of 2009 GDP) for budget support with a grant element of about 15 percent, with $2 \frac{1}{2}$ years grace and 6 years maturity. A commercial creditor associated with the construction of the N'djamena refinery has agreed to lend the Chadian partner, the state-owned Société des Hydrocarbures du Tchad (SHT), €232 million (4.1 percent of 2009 GDP) at LIBOR plus 3 percent, with 5 years grace and 10 years maturity. Disbursement of the entire budget support loan is assumed in 2010, the refinery loan in equal tranches this year and next, leading to rapid debt accumulation in 2010-11 and sizeable debt service pressure in the medium term. The interest rate, grace period and maturity on these loans reduce the average grant element of external borrowing in the short term (Figure 1a). Given Chad's present very tight fiscal situation ( $\mid 2$ ) and the prospect of steadily declining oil revenues ( $\ \uparrow 7-8)$, it is unlikely that creditors will offer additional financing for budget support. 
10. The evolution of public debt will be driven by the volume of project loans. New borrowing is expected to comprise funding from IDA, AfDB, other multilateral lenders, Paris Club and non Paris Club lenders. ${ }^{5}$ Absent a substantial improvement in macroeconomic and public financial management performance, traditional donors (multilaterals and Paris Club) are projected to continue to provide concessional project loans at roughly the same nominal level as in the last few years. The share of new borrowing on concessional terms is projected to decline steadily over the 20-year horizon, gradually decreasing the grant element of new borrowing (Figure 1a). In the absence of an IMF arrangement, there is no target date for the HIPC completion point, and the baseline does not take into account HIPC and MDRI debt relief for which Chad is eligible (\$5). In recognition of the authorities' plans to clear accumulated arrears, and their obligation to fully repay central bank statutory advances within five years, domestic public debt declines to a negligible level by the end of 2014 .

\section{DebT SustainabiLity Analysis}

\section{A. External Debt}

11. A continuation of current policies would quickly bring the external public and publicly-guaranteed (PPG) debt burden above the thresholds. If the authorities were to continue to run a current account deficit far higher than the foreign direct investment (FDI) inflows in the oil sector, as they did in 2009 by running down their official foreign exchange reserves, external PPG debt would breach most of the sustainability thresholds (Historical scenario in Figure 1b, c, d and e; and Alternative Scenario A1 in Table 2a).

\section{Owing to the lack of financing options ( $\mid 8)$, maintaining the current policy} stance is unlikely; the authorities will have to tighten fiscal policy in synch with the trend decline in oil revenue. Under this baseline scenario, Chad's external debt remains below the thresholds through the projection period (Figure 1 and Table 1a).

\section{Chad's external debt burden indicators are highly sensitive to an oil price shock.} Across all indicative debt burden thresholds, the most extreme shock is a drop in export growth in 2011-12 proportional to a one-standard-deviation lower oil price (Most extreme shock in Figure 1 and B2 Bound Test in Table 2a). Such a shock would send the debt on a path that would breach three indicative debt burden thresholds (Figures 1b, c, and e). While severe, such a shock is plausible, given the volatility of oil prices. A shock to net non-debt creating flows (B4 Bound Test in Table 2a) results in breaches of three out of five thresholds, including one liquidity indicator, as the PV of debt service-to-export ratio is placed on an upward trajectory during the last decade of the projection horizon.

\footnotetext{
${ }^{5}$ The terms of IDA, AfDB and other multilateral loans are concessional, with grant elements ranging from 35 to 52 percent.
} 


\section{B. Public Debt}

\section{The sustainability of Chad's total public debt also hinges on fiscal adjustment.}

The inclusion of domestic debt does not alter the assessment of Chad's debt sustainability. Given the limited size of Chad's domestic debt ( $\mid 3$ ) and the fiscal adjustment underlying the baseline scenario, the public debt sustainability analysis broadly parallels the external debt sustainability analysis (Figure 2 and Table 1b).

\section{The analysis of total public debt sustainability confirms that the current fiscal} stance is not sustainable. In 2009, the authorities could accommodate a sharp reduction of oil revenue by running a large primary deficit (about 10 percent of GDP, Table 1b) which was financed by depleting the sizeable oil savings accumulated on the government's accounts at the central bank (withdrawing the equivalent of 7 percent of GDP) and using central bank statutory advances (borrowing the equivalent of 4 percent of GDP). In 2010, thanks to increased oil revenues, the authorities are expected to run a smaller primary deficit (4.9 percent of GDP), financed by drawing down a nonconcessional budget support loan ( $(99)$. Going forward, financing options are limited ( $\mid 8)$. However, if the authorities were able to secure financing to maintain the current level of spending, the resulting debt path would increase steeply, leading to an unmanageable debt and debt-service burden (Fixed Primary Balance Scenario in Figure 2, and Alternative Scenario A2 in Table 2b). A temporary shock to real GDP growth in 2011-2012 would also impair public debt sustainability (Most Extreme Shock in Figure 2 and Bound Test B1 in Table 2b).

\section{The Authorities' Views}

\section{The authorities expressed more optimism than staffs about the medium-term} fiscal outlook and their ability to raise additional debt. They expect that the improvement in the security situation will boost non-oil economic activity and non-oil revenue and allow a decline of security spending. They noted that higher-than-projected oil prices would improve the outlook. In addition, they hope that the discovery of new oil fields and other natural resources would improve public revenue in the medium term. Finally, they believe that the debt burden thresholds applicable to Chad under the DSF are too low, considering their pressing investment needs. 


\section{Main Differences from the 2008 Low-Income Country Debt Sustainability Analysis}

17. The 2010 DSA projections begin from a higher initial debt burden than anticipated in the 2008 DSA, but the baseline trajectories are broadly similar. Total public sector debt as of the end of 2009 was higher than expected in the $2008 \mathrm{DSA}^{6}{ }^{6}$ due to higher-than-expected primary spending, financed by domestic borrowing. The extension of this spending level into 2010, financed by nonconcessional external budget support, was not foreseen in the 2008 DSA. Both scenarios hinge on the trend decline in oil production and revenue and fiscal adjustment. Whereas the rate of debt accumulation was relatively stable and positive in the 2008 DSA, a different mix and terms of external financing in the 2010 DSA ( $(10)$ imply both stronger amortization pressures in the medium term and a declining average grant element throughout the projection period.

\section{Debt Distress Classification and Conclusions}

\section{Compared to last year's DSA, Chad's debt vulnerabilities have increased} because the authorities have used central bank financing and contracted two large nonconcessional external loans. These two loans will lead to a sharp increase of the debt during the next two years before amortization begins. They will also make Chad's debt dynamics more vulnerable to shocks, as they will bring Chad's debt and debt service burdens closer to the thresholds in the short term.

\section{Chad's risk of debt distress remains moderate provided that the authorities} adjust the fiscal stance to the decline in oil production. Such a baseline scenario does not lead to a breach of debt-burden thresholds. However, if current policies were continued, the resulting debt path would increase steeply, leading to an unmanageable debt and debt-service burden. While the risk of debt distress remains moderate, the more rapid increase of the debt ratios than projected in the previous DSA is cause for concern.

20. Progress toward the HIPC completion point would substantially reduce Chad's debt vulnerabilities, as HIPC and MDRI debt relief would cut external debt in half.

\footnotetext{
${ }^{6}$ IMF Country Report No. 09/68. Chad: 2008 Article IV Consultation; Staff Supplement on Debt Sustainability Analysis.
} 
Figure 1. Chad: Indicators of Public and Publicly Guaranteed External Debt under Alternative Scenarios, 2010-2030 1/

a. Debt Accumulation

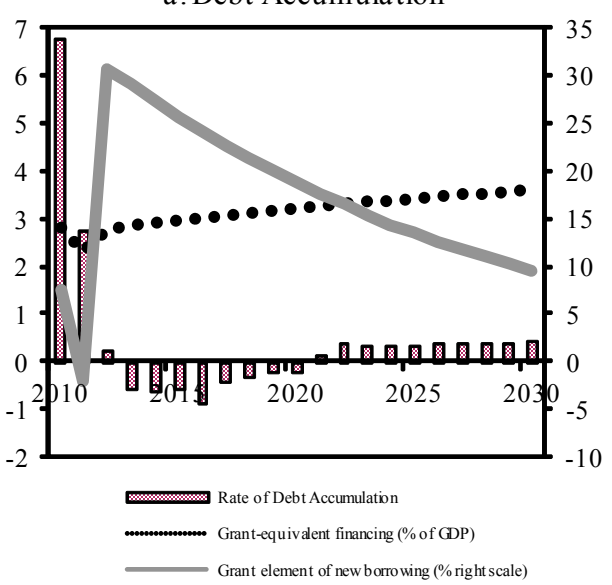

c.PV of debt-to-exports ratio
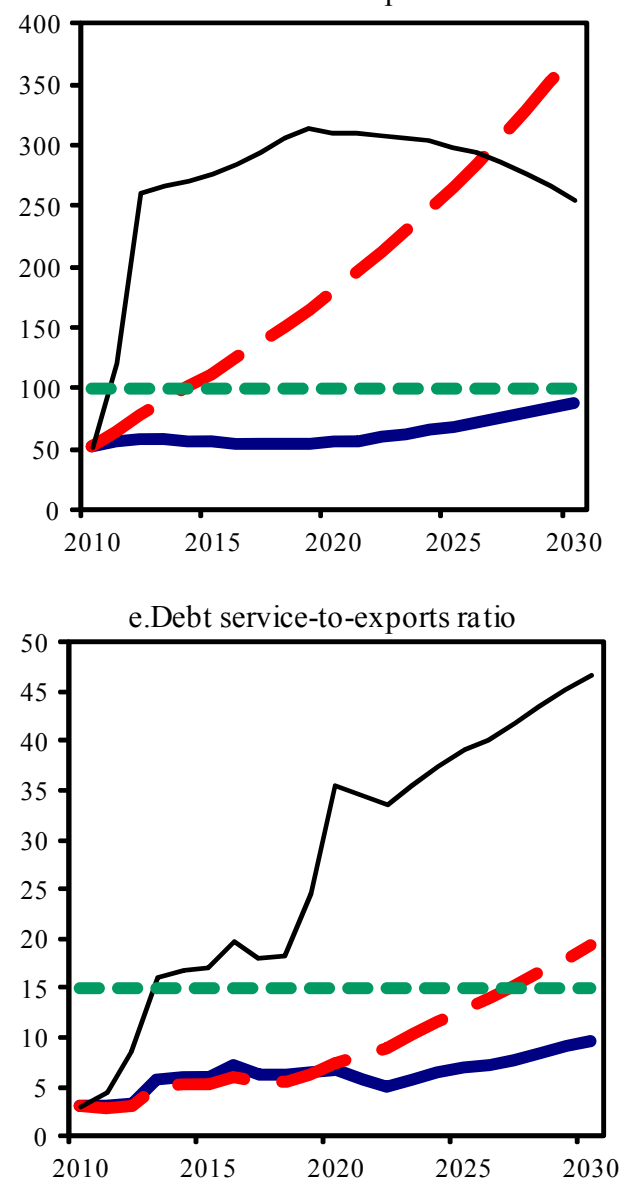
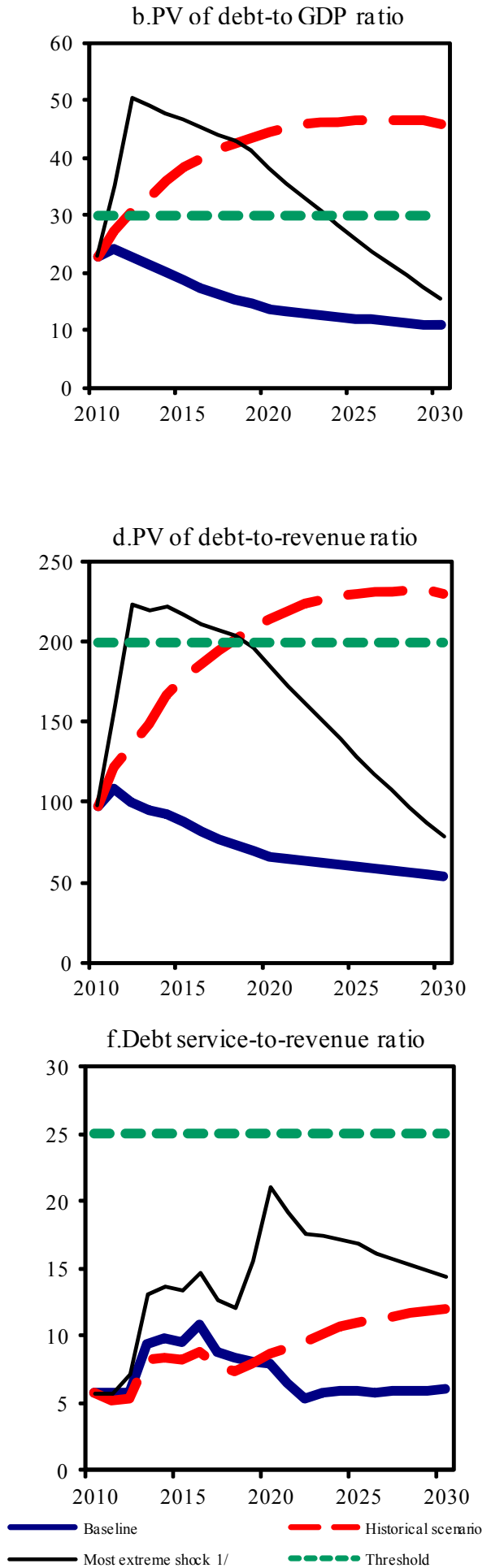

Sources: Country authorities; and staff estimates and projections.

$1 /$ The most extreme stress test is a shock to export growth proportional to a one-standard-deviation lower oil price in 2011 and 2012 . 
Figure 2.Chad: Indicators of Public Debt Under Alternative Scenarios, 2010-2030 1/
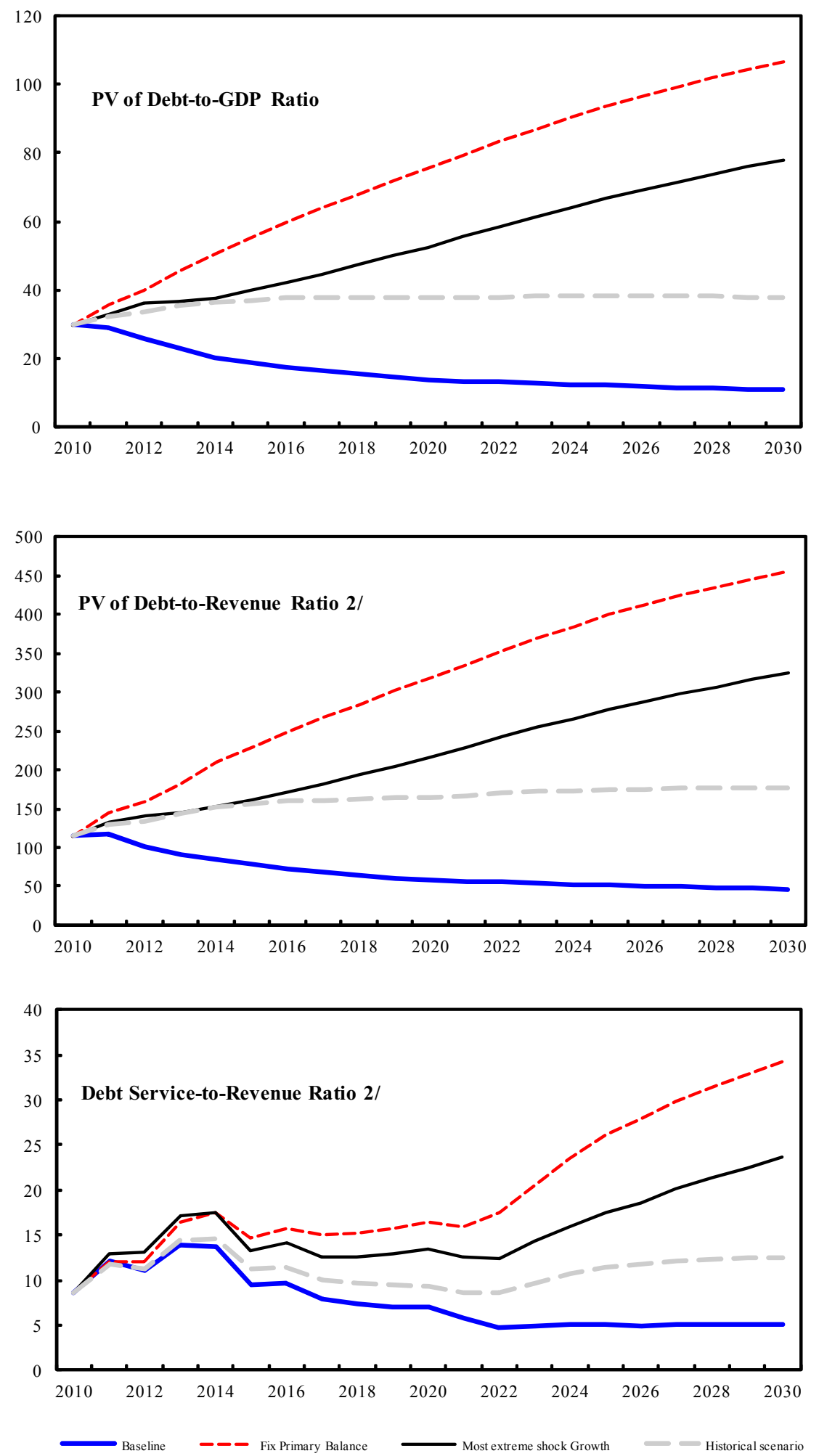

Sources: Country authorities; and staff estimates and projections.

1/ The most extreme stress test is the test that yields the highest ratio in 2020.

2/ Revenues are defined inclusive of grants. 
Table 1a.: External Debt Sustainability Framework, Baseline Scenario, 2007-2030 1/ (In percent of GDP, unless otherwise indicated)

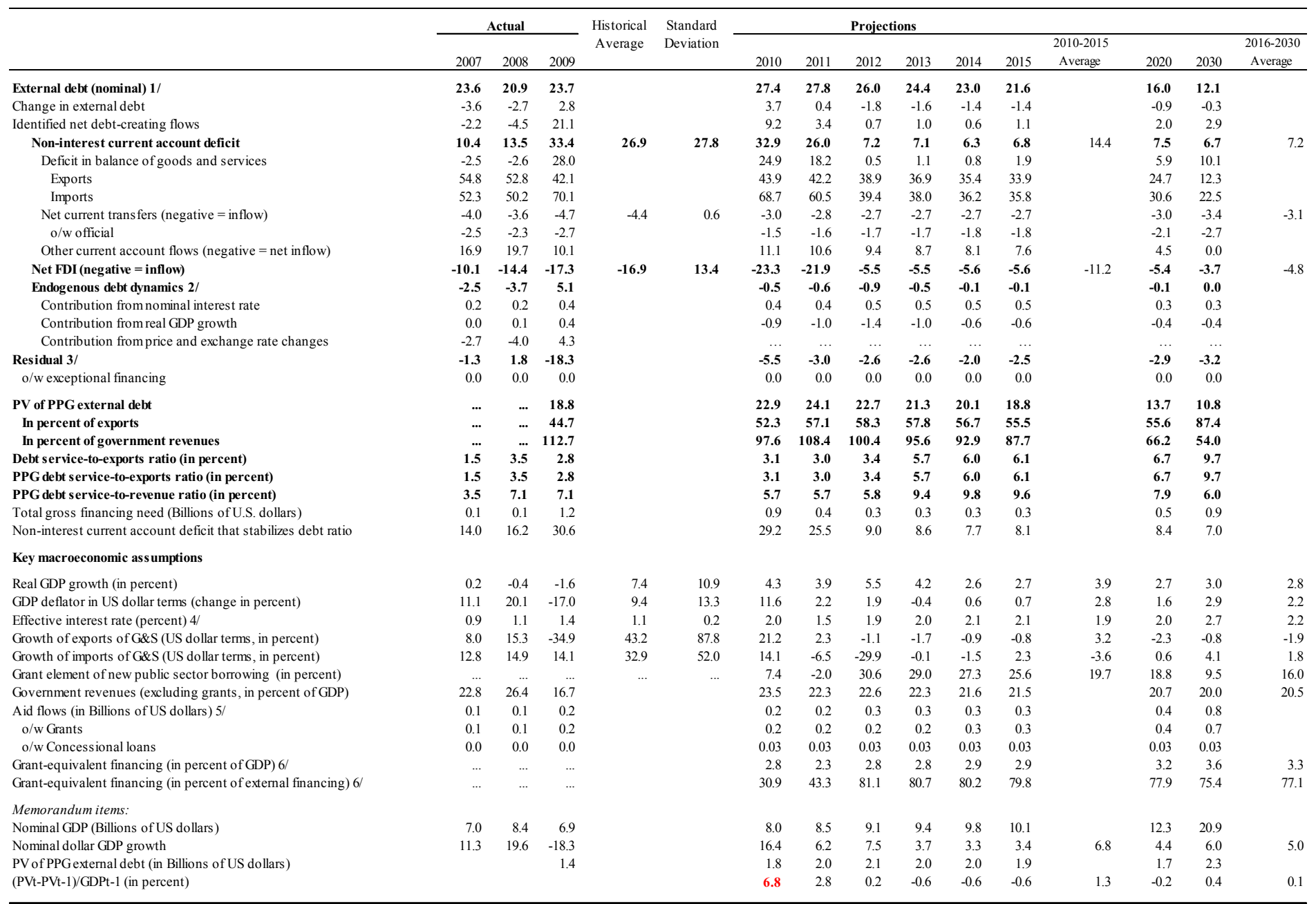

Sources: Country authorities; and staff estimates and projections.

2/ Derived as $[\mathrm{r}-\mathrm{g}-\rho(1+\mathrm{g}) /(1+\mathrm{g}+\rho+\mathrm{\rho} \rho)$ times previous period debt ratio, with $\mathrm{r}=$ nominal interest rate; $\mathrm{g}=$ real GDP growth rate, and $\rho=$ growth rate of GDP deflator in U.S. dollar terms.

3/ For 2009, includes a reduction in foreign reserves equivalent to 11 percent of GDP. Also includes any exceptional financing (i.e., changes in arrears and debt relief) and valuation adjustments.

4/ Current-year interest payments divided by previous period debt stock.

$5 /$ Defined as grants, concessional loans, and debt relief.

6/ Grant-equivalent financing includes grants provided directly to the government and through new borrowing (difference between the face value and the PV of new debt). 
Table 1b. Chad: Public Sector Debt Sustainability Framework, Baseline Scenario, 2007-2030 (In percent of GDP, unless otherwise indicated)

\begin{tabular}{|c|c|c|c|c|c|c|c|c|c|c|c|c|c|c|c|}
\hline & \multicolumn{3}{|c|}{ Actual } & \multirow[b]{2}{*}{ Average } & \multirow[b]{2}{*}{$\begin{array}{c}\text { Standard } \\
\text { Deviation }\end{array}$} & \multicolumn{5}{|l|}{ Estimate } & \multicolumn{5}{|c|}{ Projections } \\
\hline & 2007 & 2008 & 2009 & & & 2010 & 2011 & 2012 & 2013 & 2014 & 2015 & $\begin{array}{c}2010-15 \\
\text { Average }\end{array}$ & 2020 & 2030 & $\begin{array}{c}2016-30 \\
\text { Average }\end{array}$ \\
\hline Public sector debt 1/ & 26.0 & 23.6 & 31.4 & & & 34.2 & 32.4 & 28.9 & 25.8 & 23.2 & 21.6 & & 16.0 & 12.1 & \\
\hline $\mathrm{o} / \mathrm{w}$ foreign-currency denominated & 23.6 & 20.9 & 23.7 & & & 27.4 & 27.8 & 26.0 & 24.4 & 23.0 & 21.6 & & 16.0 & 12.1 & \\
\hline Change in public sector debt & -3.6 & -2.4 & 7.8 & & & 2.8 & -1.8 & -3.6 & -3.0 & -2.6 & -1.6 & & -0.9 & -0.3 & \\
\hline Identified debt-creating flows & -6.2 & -5.6 & 12.4 & & & 1.6 & -3.4 & -4.5 & -4.0 & -3.0 & -1.3 & & -0.3 & 0.1 & \\
\hline Primary deficit & -3.4 & -4.8 & 9.8 & 2.4 & 4.8 & 4.9 & -1.9 & -2.9 & -3.5 & -2.7 & -1.0 & -1.2 & 0.1 & 0.5 & 0.1 \\
\hline Revenue and grants & 24.2 & 27.9 & 20.3 & & & 25.8 & 24.6 & 25.1 & 24.9 & 24.2 & 24.2 & & 23.7 & 23.5 & \\
\hline of which: grants & 1.5 & 1.5 & 3.6 & & & 2.3 & 2.4 & 2.5 & 2.6 & 2.6 & 2.7 & & 3.0 & 3.5 & \\
\hline Primary (noninterest) expenditure & 20.8 & 23.1 & 30.1 & & & 30.7 & 22.7 & 22.2 & 21.3 & 21.5 & 23.2 & & 23.8 & 23.9 & \\
\hline Automatic debt dynamics & -2.8 & -0.9 & 2.6 & & & -2.7 & -1.5 & -1.7 & -0.5 & -0.3 & -0.3 & & -0.4 & -0.4 & \\
\hline Contribution from interest rate/growth differential & -0.5 & -0.3 & 1.0 & & & -1.6 & -1.3 & -1.7 & -1.1 & -0.6 & -0.6 & & -0.5 & -0.3 & \\
\hline of which: contribution from average real interest rate & -0.5 & -0.5 & 0.6 & & & -0.3 & 0.0 & 0.0 & 0.1 & 0.0 & 0.0 & & 0.0 & 0.1 & \\
\hline of which: contribution from real GDP growth & -0.1 & 0.1 & 0.4 & & & -1.3 & -1.3 & -1.7 & -1.2 & -0.7 & -0.6 & & -0.4 & -0.4 & \\
\hline Contribution from real exchange rate depreciation & -2.2 & -0.5 & 1.6 & & & -1.1 & -0.2 & 0.0 & 0.6 & 0.3 & 0.3 & & $\ldots$ & $\ldots$ & \\
\hline Other identified debt-creating flows & 0.0 & 0.0 & 0.0 & & & -0.5 & 0.0 & 0.0 & 0.0 & 0.0 & 0.0 & & 0.0 & 0.0 & \\
\hline Privatization receipts (negative) & 0.0 & 0.0 & 0.0 & & & -0.5 & 0.0 & 0.0 & 0.0 & 0.0 & 0.0 & & 0.0 & 0.0 & \\
\hline Recognition of implicit or contingent liabilities & 0.0 & 0.0 & 0.0 & & & 0.0 & 0.0 & 0.0 & 0.0 & 0.0 & 0.0 & & 0.0 & 0.0 & \\
\hline Debt relief (HIPC and other) & 0.0 & 0.0 & 0.0 & & & 0.0 & 0.0 & 0.0 & 0.0 & 0.0 & 0.0 & & 0.0 & 0.0 & \\
\hline Other (specify, e.g. bank recapitalization) & 0.0 & 0.0 & 0.0 & & & 0.0 & 0.0 & 0.0 & 0.0 & 0.0 & 0.0 & & 0.0 & 0.0 & \\
\hline Residual, including asset changes & 2.6 & 3.3 & -4.5 & & & 1.1 & 1.7 & 1.0 & 1.0 & 0.4 & -0.3 & & -0.6 & -0.4 & \\
\hline \multicolumn{16}{|l|}{ Other S ustainability Indicators } \\
\hline PV of public sector debt & 2.4 & 2.7 & 26.6 & & & 29.7 & 28.8 & 25.6 & 22.8 & 20.3 & 18.8 & & 13.7 & 10.8 & \\
\hline $\mathrm{o} / \mathrm{w}$ foreign-currency denominated & 0.0 & 0.0 & 18.8 & & & 22.9 & 24.1 & 22.7 & 21.3 & 20.1 & 18.8 & & 13.7 & 10.8 & \\
\hline o/w external & $\ldots$ & $\ldots$ & 18.8 & & & 22.9 & 24.1 & 22.7 & 21.3 & 20.1 & 18.8 & & 13.7 & 10.8 & \\
\hline PV of contingent liabilities (not included in public sector debt) & $\ldots$ & & $\ldots$ & & & $\ldots$ & $\ldots$ & & $\ldots$ & & & & $\ldots$ & $\ldots$ & \\
\hline Gross financing need $2 /$ & -0.8 & -2.2 & 13.0 & & & 7.8 & 1.1 & -0.1 & 0.0 & 0.6 & 1.3 & & 1.8 & 1.7 & \\
\hline $\mathrm{PV}$ of public sector debt-to-revenue and grants ratio (in percent) & 9.7 & 9.6 & 131.0 & & & 115.2 & 116.8 & 102.0 & 91.6 & 83.8 & 78.0 & & 57.9 & 46.0 & \\
\hline PV of public sector debt-to-revenue ratio (in percent) & 10.3 & 10.2 & 159.0 & & & 126.6 & 129.2 & 113.2 & 102.1 & 94.0 & 87.7 & & 66.2 & 54.0 & \\
\hline o/w external 3/ & & & 112.7 & & & 97.6 & 108.4 & 100.4 & 95.6 & 92.9 & 87.7 & & 66.2 & 54.0 & \\
\hline Debt service-to-revenue and grants ratio (in percent) $4 /$ & 7.7 & 6.9 & 9.5 & & & 8.7 & 12.1 & 11.1 & 14.0 & 13.6 & 9.5 & & 6.9 & 5.1 & \\
\hline Debt service-to-revenue ratio (in percent) $4 /$ & 8.1 & 7.2 & 11.5 & & & 9.6 & 13.4 & 12.3 & 15.6 & 15.3 & 10.7 & & 7.9 & 6.0 & \\
\hline Primary deficit that stabilizes the debt-to-GDP ratio & 0.2 & -2.4 & 2.0 & & & 2.1 & -0.1 & 0.7 & -0.5 & -0.1 & 0.6 & & 1.0 & 0.8 & \\
\hline \multicolumn{16}{|l|}{ Key macroeconomic and fiscal assumptions } \\
\hline Real GDP growth (in percent) & 0.2 & -0.4 & -1.6 & 7.4 & 10.9 & 4.3 & 3.9 & 5.5 & 4.2 & 2.6 & 2.7 & 3.9 & 2.7 & 3.0 & 2.8 \\
\hline Average nominal interest rate on forex debt (in percent) & 0.9 & 1.1 & 1.4 & 1.1 & 0.2 & 2.0 & 1.5 & 1.9 & 2.0 & 2.1 & 2.1 & 1.9 & 2.0 & $2.7^{\prime \prime}$ & 2.2 \\
\hline Average real interest rate on domestic debt (in percent) & 2.0 & -9.0 & 19.9 & 2.6 & 12.4 & -7.4 & -0.2 & 0.5 & 2.6 & 0.8 & -0.3 & $\ldots$ & $\ldots$ & $\ldots$ & $\ldots$ \\
\hline Real exchange rate depreciation (in percent, + indicates depreciation) & -8.4 & -2.3 & 7.7 & -6.3 & 8.8 & -4.6 & $\ldots$ & & $\ldots$ & & & & $\ldots$ & $\ldots$ & \\
\hline Inflation rate (GDP deflator, in percent) & 1.8 & 11.8 & -12.3 & 6.1 & 9.5 & 11.6 & 3.2 & 2.5 & 0.2 & 1.2 & 1.3 & 3.4 & 1.6 & 2.9 & 2.2 \\
\hline Growth of real primary spending (deflated by GDP deflator, in percent) & 0.3 & 0.1 & 0.3 & 0.1 & 0.2 & 0.1 & -0.2 & 0.0 & 0.0 & 0.0 & 0.1 & 0.0 & 0.0 & 0.0 & 0.0 \\
\hline Grant element of new external borrowing (in percent) & $\ldots$ & $\ldots$ & $\ldots$ & $\ldots$ & $\ldots$ & 7.4 & -2.0 & 30.6 & 29.0 & 27.3 & 25.6 & 19.7 & 18.8 & 9.5 & \\
\hline
\end{tabular}

/ Gross debt of the central government including debts guaranteed for, or assumed from, state-owned enterprises.

2/ Gross financing need is defined as the primary deficit plus debt service plus the stock of short-term debt at the end of the last period.

$3 /$ Revenues excluding grants.

4/ Debt service is defined as the sum of interest and amortization of medium and long-term debt.

$5 /$ Historical averages and standard deviations are generally derived over the past 10 years, subject to data availability 


\begin{tabular}{|c|c|c|c|c|c|c|c|c|c|c|c|c|}
\hline & \multicolumn{12}{|c|}{ Projections } \\
\hline & 2010 & 2011 & 2012 & 2013 & 2014 & 2015 & 2016 & 2017 & 2018 & 2019 & 2020 & 2030 \\
\hline \multicolumn{13}{|c|}{ PV of de bt-to GDP ratio } \\
\hline Baseline & 23 & 24 & 23 & 21 & 20 & 19 & 17 & 16 & 15 & 15 & 14 & 11 \\
\hline \multicolumn{13}{|l|}{ A. Alternative Scenarios } \\
\hline A1. Key variables at their historical averages in 2010-2030 1/ & 23 & 27 & 31 & 33 & 36 & 38 & 40 & 41 & 42 & 44 & 44 & 46 \\
\hline B1. Real GDP growth at historical average minus one standard deviation in 2011-2012 & 23 & 26 & 27 & 25 & 24 & 22 & 20 & 19 & 18 & 17 & 16 & 13 \\
\hline B2. Export value growth at baseline minus a one-standard-deviation lower oil price in 2011-2012 3/ & 23 & 35 & 50 & 49 & 48 & 47 & 45 & 44 & 43 & 41 & 38 & 16 \\
\hline B3. US dollar GDP deflator at historical average minus one standard deviation in 2011-2012 & 23 & 26 & 25 & 24 & 23 & 21 & 20 & 18 & 17 & 16 & 15 & 12 \\
\hline B4. Net non-debt creating flows at historical average minus one standard deviation in 2011-2012 4/ & 23 & 39 & 38 & 37 & 35 & 34 & 33 & 32 & 31 & 29 & 27 & 13 \\
\hline B5. Combination of B1-B4 using one-half standard deviation shocks & 23 & 35 & 30 & 28 & 27 & 26 & 24 & 23 & 22 & 21 & 19 & 12 \\
\hline B6. One-time 30 percent nominal depreciation relative to the baseline in 2011 5/ & 23 & 34 & 32 & 30 & 28 & 27 & 25 & 23 & 22 & 20 & 19 & 15 \\
\hline
\end{tabular}

PV of debt-to-exports ratio

\section{Baseline}

A. Alternative Scenarios

A1. Key variables at their historical averages in 2010-2030 $1 /$

A2. New public sector loans on less favorable terms in 2010-2030 2

\section{B. Bound Tests}

B1. Real GDP growth at historical average minus one standard deviation in 2011-2012 B2. Export value growth at baseline minus a one-standard-deviation lower oil price in 2011-2012 3/ B3. US dollar GDP deflator at historical average minus one standard deviation in 2011-2012 B4. Net non-debt crating flows at historical avere minus one standerd devintion in 2011-20124 B5. Combination of B1-B4 using one-half standard deviation shock

B6. One-time 30 percent nominal depreciation relative to the baseline in $20115 /$

$\begin{array}{rrrrrrrrrrrr}52 & 57 & 58 & 58 & 57 & 56 & 54 & 54 & 55 & 55 & \mathbf{5 6} & 87 \\ & & & & & & & & & & & \\ 52 & 64 & 79 & 90 & 102 & 113 & 125 & 137 & 151 & 165 & \mathbf{1 8 0} & 372 \\ 52 & 57 & 59 & 60 & 59 & 59 & 59 & 60 & 62 & 63 & \mathbf{6 6} & 123 \\ & & & & & & & & & & & \\ & & & & & & & & & & & \\ 52 & 57 & 58 & 58 & 57 & 55 & 54 & 54 & 54 & 55 & \mathbf{5 5} & 87 \\ 52 & 120 & 260 & 267 & 271 & 276 & 283 & 294 & 306 & 313 & \mathbf{3 1 0} & 254 \\ 52 & 57 & 58 & 58 & 57 & 55 & 54 & 54 & 54 & 55 & \mathbf{5 5} & 87 \\ 52 & 93 & 98 & 99 & 100 & 101 & 102 & 105 & 109 & 109 & \mathbf{1 0 8} & 105 \\ 52 & 84 & 76 & 76 & 76 & 75 & 75 & 76 & 78 & 77 & \mathbf{7 7} & 95 \\ 52 & 57 & 58 & 58 & 57 & 55 & 54 & 54 & 54 & 55 & \mathbf{5 5} & 87\end{array}$

Baseline

A. Alternative Scenarios

A1. Key variables at their historical averages in 2010-2030 1/ A2. New public sector loans on less favorable terms in 2010-2030

PV of debt-to-revenue ratio

\section{B. Bound Tests}

B1. Real GDP growth at historical average minus one standard deviation in 2011-2012 B2. Export value growth at baseline minus a one-standard-deviation lower oil price in 2011-2012 3/ B3. US dollar GDP deflator at historical average minus one standard deviation in 2011-2012
B4. Net non-debt creating flows at historical average minus one standard deviation in 2011-2012 4/

B5. Combination of B1-B4 using one-half standard deviation shock

B6. One-time 30 percent nominal depreciation relative to the baseline in 2011 /

$\begin{array}{rrrrrrrrrrrr}98 & 108 & 100 & 96 & 93 & 88 & 81 & 77 & 73 & 70 & \mathbf{6 6} & 54 \\ & & & & & & & & & & & \\ 98 & 122 & 135 & 148 & 167 & 178 & 187 & 195 & 202 & 209 & \mathbf{2 1 4} & 230 \\ 98 & 108 & 102 & 99 & 97 & 93 & 88 & 85 & 82 & 80 & \mathbf{7 8} & 76 \\ & & & & & & & & & & & \\ & & & & & & & & & & & \\ 98 & 116 & 118 & 112 & 109 & 103 & 96 & 90 & 86 & 82 & \mathbf{7 8} & 63 \\ 98 & 158 & 223 & 220 & 221 & 217 & 211 & 207 & 204 & 197 & \mathbf{1 8 4} & 78 \\ 98 & 115 & 113 & 107 & 104 & 99 & 91 & 86 & 82 & 78 & \mathbf{7 4} & 61 \\ 98 & 176 & 168 & 164 & 164 & 159 & 153 & 149 & 146 & 137 & \mathbf{1 2 9} & 65 \\ 98 & 157 & 132 & 128 & 126 & 121 & 114 & 110 & 106 & 99 & \mathbf{9 3} & 59 \\ 98 & 153 & 142 & 135 & 131 & 124 & 115 & 109 & 103 & 98 & \mathbf{9 3} & 76\end{array}$




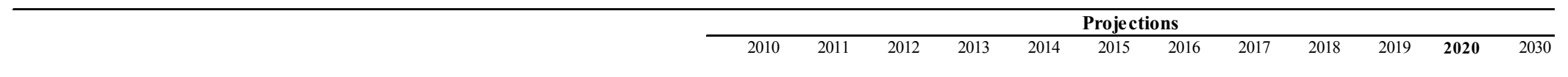

Debt service-to-exports ratio

\section{Baseline}

\section{A. Alternative Scenarios}

A1. Key variables at their historical averages in 2010-2030 1

A2. New public sector loans on less favorable terms in 2010-2030 2

\section{B. Bound Tests}

B1. Real GDP growth at historical average minus one standard deviation in 2011-2012 B2. Export value growth at baseline minus a one-standard-deviation lower oil price in 2011-20123/ B3. US dollar GDP deflator at historical average minus one standard deviation in 2011-2012 B4. Net non-debt creating flows at historical average minus one standard deviation in 2011-2012 4/ B5. Combination of B1-B4 using one-half standard deviation shocks

B6. One-time 30 percent nominal depreciation relative to the baseline in 2011 5/

\section{Debt service-to-revenue ratio}

\section{Baseline}

\section{A. Alternative Scenarios}

A1. Key variables at their historical averages in 2010-2030 1

A2. New public sector loans on less favorable terms in 2010-2030 2/

\section{B. Bound Tests}

B1. Real GDP growth at historical average minus one standard deviation in 2011-2012

B2. Export value growth at baseline minus a one-standard-deviation lower oil price in 2011-2012 3

B3. US dollar GDP deflator at historical average minus one standard deviation in 2011-2012

B4. Net non-debt creating flows at historical average minus one standard deviation in 2011-2012 4

B5. Combination of B1-B4 using one-half standard deviation shocks

B6. One-time 30 percent nominal depreciation relative to the baseline in $20115 /$

Memorandum item:

Grant element assumed on residual financing (i.e., financing required above baseline) 6/

Sources: Country authorities; and staff estimates and projections.

1/ Variables include real GDP growth, growth of GDP deflator (in U.S. dollar terms), non-interest current account in percent of GDP, and non-debt creating flows.

2/ Assumes that the interest rate on new borrowing is by 2 percentage points higher than in the baseline., while grace and maturity periods are the same as in the baseline.

3/ Exports values are assumed to remain permanently at the lower level, but the current account as a share of GDP is assumed to return to its baseline level after the shock (implicitly assuming an offsetting adjustment in import levels).

4/ Includes official and private transfers and FDI.

$5 /$ Depreciation is defined as percentage decline in dollar/local currency rate, such that it never exceeds 100 percent.

6/ Applies to all stress scenarios except for A2 (less favorable financing) in which the terms on all new financing are as specified in footnote 2. 
Table 2b. Chad: Sensitivity Analysis for Key Indicators of Public Debt 2010-2030

PV of Debt-to-GDP Ratio
Bas eline
A. Alternative Scenarios
A1. Real GDP growth and primary balance are at historical averages
A2. Primary balance is unchanged from 2010
A3. Permanently lower GDP growth 1/
B. Bound Tests
B1. Real GDP growth is at historical average minus one standard deviations in 2011-2012
B2. Primary balance is at historical average minus one standard deviations in 2011-2012
B3. Combination of B1-B2 using one half standard deviation shocks
B4. One-time 30 percent real depreciation in 2011
B5. 10 percent of GDP increase in other debt-creating flows in 2011

Projections

Baseline

PV of Debt-to-Revenue Ratio 2/

\section{Bas eline}

\section{A. Alternative Scenarios}

A1. Real GDP growth and primary balance are at historical averages

A2. Primary balance is unchanged from 2010

A3. Permanently lower GDP growth 1

\section{B. Bound Tests}

B1. Real GDP growth is at historical average minus one standard deviations in 2011-2012 B2. Primary balance is at historical average minus one standard deviations in 2011-2012

B3. Combination of B1-B2 using one half standard deviation shocks

B4. One-time 30 percent real depreciation in 2011

B5. 10 percent of GDP increase in other debt-creating flows in 2011

Debt Service-to-Revenue Ratio 2

$\begin{array}{llllllll}30 & 29 & 26 & 23 & 20 & 19 & 14 & 11\end{array}$

$\begin{array}{rrrrrrrr}30 & 32 & 33 & 35 & 37 & 37 & 38 & 38 \\ 30 & 36 & 40 & 45 & 51 & 55 & 75 & 107 \\ 30 & 30 & 28 & 28 & 28 & 30 & 50 & 148\end{array}$

$\begin{array}{llllllll}30 & 33 & 36 & 37 & 38 & 40 & 53 & 78 \\ 30 & 38 & 44 & 42 & 39 & 38 & 33 & 27 \\ 30 & 36 & 42 & 40 & 39 & 38 & 39 & 43 \\ 30 & 39 & 35 & 32 & 30 & 28 & 23 & 20 \\ 30 & 39 & 35 & 32 & 30 & 29 & 24 & 19\end{array}$

$\begin{array}{llllllll}115 & 117 & 102 & 92 & 84 & 78 & 58 & 46\end{array}$

$\begin{array}{llllllll}115 & 130 & 134 & 144 & 153 & 156 & 165 & 176 \\ 115 & 144 & 159 & 183 & 209 & 229 & 318 & 455\end{array}$

$\begin{array}{llllllll}115 & 144 & 159 & 183 & 209 & 229 & 318 & 455 \\ 115 & 122 & 113 & 111 & 114 & 121 & 204 & 578\end{array}$

$\begin{array}{rrrrrrrr}115 & 132 & 141 & 145 & 153 & 162 & 217 & 324 \\ 115 & 154 & 177 & 168 & 163 & 157 & 138 & 117 \\ 115 & 146 & 165 & 159 & 158 & 158 & 162 & 182 \\ 115 & 157 & 140 & 129 & 123 & 117 & 98 & 87 \\ 115 & 157 & 141 & 131 & 124 & 119 & 99 & 82\end{array}$

Baseline

\section{A. Alternative Scenarios}

A1. Real GDP growth and primary balance are at historical averages A2. Primary balance is unchanged from 2010

A3. Permanently lower GDP growth $1 /$

$\begin{array}{rrrrrrrr}9 & 12 & 11 & 15 & 15 & 11 & 9 & 13 \\ 9 & 12 & 12 & 16 & 18 & 15 & 16 & 34 \\ 9 & 12 & 12 & 15 & 15 & 12 & 13 & 33\end{array}$

\section{B. Bound Tests}

B1. Real GDP growth is at historical average minus one standard deviations in 2011-2012 B2. Primary balance is at historical average minus one standard deviations in 2011-2012

B3. Combination of B1-B2 using one half standard deviation shocks

B4. One-time 30 percent real depreciation in 2011

B5. 10 percent of GDP increase in other debt-creating flows in 2011

$\begin{array}{rrrrrrrr}9 & 13 & 13 & 17 & 17 & 13 & 13 & 24 \\ 9 & 12 & 12 & 17 & 17 & 13 & 10 & 13 \\ 9 & 12 & 13 & 17 & 17 & 13 & 11 & 16 \\ 9 & 13 & 13 & 18 & 18 & 14 & 11 & 11 \\ 9 & 12 & 13 & 16 & 15 & 11 & 9 & 9\end{array}$

Sources: Country authorities; and staff estimates and projections

1/ Assumes that real GDP growth is at baseline minus one standard deviation divided by the square root of the length of the projection period.

2 / Revenues are defined inclusive of grants. 
INTERNATIONAL MONETARY FUND

CHAD

Staff Report for the 2010 Article IV Consultation-Supplementary Information

\author{
Prepared by the African Department \\ (In Consultation with Other Departments) \\ Approved by Seán Nolan and Dhaneshwar Ghura
}

June 16,2010

Information just received by staff points to a change in the Chadian government's policy to address food shortages. As indicated in paragraph 18 of the Article IV Consultation Staff Report, information available to the staff at the time of the mission was that the government had ordered 33,000 tons of food to address food shortages. Staff has learned in recent days that tenders covering some 20,000 tons of food have been allowed to lapse.

Based on information obtained from specialized agencies, staff believes that this cutback in orders could pose an important threat to food relief efforts. 


\section{INTERNATIONAL MONETARY FUND}

EXTERNAL

Public Information Notice (PIN) No. 10/77 FOR IMMEDIATE RELEASE

June 21, 2010
International Monetary Fund

$70019^{\text {th }}$ Street, NW

Washington, D. C. 20431 USA

\section{IMF Executive Board Concludes 2010 Article IV Consultation with Chad}

On June 16, 2010, the Executive Board of the International Monetary Fund (IMF) concluded the Article IV consultation with Chad. ${ }^{1}$

\section{Background}

Chad is among the poorest countries in the world. It has experienced conflict for most of the past thirty years. The country's key medium-term challenge is to seize the opportunity provided by oil production since 2003 to increase growth of the nonoil sector and reduce poverty. The second Poverty Reduction Strategy Paper (PRSP) highlights the importance of fiscal sustainability, sound public financial management, and high quality spending to promote diversification of the economy and reduce poverty.

Output contracted by 2 percent in 2009 because of a large reduction in agricultural production due to poor rainfall and the trend decrease of oil production. Inflation increased to 10 percent in 2009 , but has started to wane in the aftermath of the fuel and food crisis.

The bad harvest could imply food shortages for up to 2 million people (18 percent of the population). The need for additional food is estimated at between 80,000 and

\footnotetext{
${ }^{1}$ Under Article IV of the IMF's Articles of Agreement, the IMF holds bilateral discussions with members, usually every year. A staff team visits the country, collects economic and financial information, and discusses with officials the country's economic developments and policies. On return to headquarters, the staff prepares a report, which forms the basis for discussion by the Executive Board. At the conclusion of the discussion, the Managing Director, as Chairman of the Board, summarizes the views of Executive Directors, and this summary is transmitted to the country's authorities. An explanation of any qualifiers used in summings up can be found here: http://www.imf.org/external/np/sec/misc/qualifiers.htm.
} 
100,000 metric tons, which the government has started to meet in cooperation with donors.

The global financial crisis affected Chad mainly through the decline in oil prices. The fiscal position deteriorated sharply in 2009 as the government increased spending levels while oil revenue collapsed. The overall fiscal balance moved from a sizeable surplus (some 7 percent of non-oil gross domestic product -- GDP) in 2008 to a large deficit (about 21 percent of non-oil GDP) in 2009, which was financed by the depletion of oil savings, borrowing from the regional central bank, and foreign financing (mainly grants).

The fall in oil prices in 2009 induced a sharp deterioration of both the current account and the overall balance of the balance of payments, and a reduction of imputed gross official reserves (to 3 months of imports of goods and services, excluding oil sector imports financed by the oil consortium).

As a member of the CFA franc zone, Chad has no independent monetary policy. Broad money contracted slightly in 2009 in line with the drop in economic activity. The banking sector is subject to vulnerabilities, stemming from its lack of depth, high credit concentration, the fragile situation of some banks, insufficient on-site supervision, the poor functioning of the judiciary system, and, more broadly, the underdevelopment of financial markets in the Central African Economic and Monetary Community.

The macroeconomic outlook is shaped by the expected rebound of agriculture, the construction of a second oil extraction project, the gradual recovery of oil prices, and the need for fiscal adjustment in response to financing constraints.

\section{Executive Board Assessment}

Executive Directors noted that the global financial crisis has affected Chad mainly through the decline in oil prices, which caused a large deterioration in the balance of payments and the fiscal position. At the same time, GDP contracted as a result of a large drop in agricultural production. While agricultural output is expected to recover, there is an impending food shortage that needs to be addressed urgently. Over the medium term, the trend decline in oil resources will require significant fiscal policy adjustment.

Directors expressed concern over the looming food shortage. They urged prompt further action to fill the food shortfall in time to avoid famine. Further efforts to improve agricultural productivity will be critical to prevent the recurrence of food shortages.

Directors noted the large deterioration of the fiscal position in 2009, the depletion of oil savings, and the sizable increase in public debt arising from two large nonconcessional loans and borrowings from the regional central bank. To ensure 
debt sustainability, Directors advised the authorities to tighten fiscal policy within a medium-term framework that factors in the trend decline of oil production over the next 20 years. This would entail steadily reducing the non-oil primary deficit while focusing spending on priority areas. Directors recommended adopting a supplementary budget for 2010 along these lines. They encouraged the authorities to refrain from nonconcessional borrowing.

Directors emphasized that improving public financial management is key to transforming oil wealth into sustained growth and making progress toward the Millennium Development Goals. The main priorities are preserving the exemplary transparency of oil revenue, implementing the Extractive Industry Transparency Initiative, expanding recent improvements in tax administration, aligning spending with the Poverty Reduction Strategy, and improving public investment planning and procurement. Improved fiscal policy and public financial management would also pave the way for a timely agreement on a new staff monitored program.

Directors noted the assessment that the current level of the real effective exchange rate does not pose immediate problems for external sustainability, although significant fiscal adjustment will be needed over time. To improve competitiveness, a more supportive business climate is needed to promote private-sector non-oil growth. Directors called for early action to improve the judicial system, deepen the financial sector and ensure compliance of banks with prudential guidelines, and reform the state-owned cotton and utility companies.

Directors encouraged the authorities to allocate sufficient resources to statistical collection and analysis to address the shortcomings in Chad's macroeconomic statistics.

Directors commended the authorities for preparing a frank and comprehensive second National Poverty Reduction Strategy (NPRS II) that draws on the lessons learned during the implementation of the first NPRS. They welcomed the focus on restoring security, improving governance, achieving a greater diversification of the economy, strengthening institutional capacity, and promoting human development. They stressed that success hinges on a strengthened commitment to poverty reduction and good governance, and encouraged the authorities to focus on a manageable number of critical objectives and to closely monitor implementation progress.

Public Information Notices (PINs) form part of the IMF's efforts to promote transparency of the IMF's views and analysis of economic developments and policies. With the consent of the country (or countries) concerned, PINs are issued after Executive Board discussions of Article IV consultations with member countries, of its surveillance of developments at the regional level, of post-program monitoring, and of ex post assessments of member countries with longer-term program engagements. PINs are also issued after Executive Board discussions of general policy matters, unless otherwise decided by the Executive Board in a particular case. 
Chad: Selected Economic Indicators, 2008-12

\begin{tabular}{|c|c|c|c|c|c|}
\hline & 2008 & 2009 & 2010 & 2011 & 2012 \\
\hline & \multicolumn{5}{|c|}{ (Annual percentage change) } \\
\hline Real GDP & -0.4 & -1.6 & 4.3 & 3.9 & 5.5 \\
\hline Oil GDP & -11.5 & -5.2 & 2.1 & -2.2 & -7.5 \\
\hline Non-oil GDP & 3.2 & -0.5 & 4.9 & 5.5 & 8.7 \\
\hline Consumer price index (average) & 8.3 & 10.1 & 6.0 & 3.0 & 3.0 \\
\hline Oil production (in million barrels) & 46.6 & 43.6 & 44.0 & 43.0 & 42.0 \\
\hline Broad money & 24.7 & -4.0 & 20.0 & 9.2 & 13.5 \\
\hline Exports, f.o.b. & 7.4 & -31.2 & 21.2 & 3.4 & -0.5 \\
\hline Imports, f.o.b. & 7.0 & 20.6 & 14.1 & -5.6 & -29.5 \\
\hline \multirow[t]{2}{*}{ Current account (in percent of GDP) } & -13.7 & -33.7 & -33.1 & -26.1 & -7.4 \\
\hline & \multicolumn{5}{|c|}{ (Percent of non-oil GDP) } \\
\hline Total revenue & 48.6 & 25.2 & 37.2 & 34.7 & 33.5 \\
\hline Total expenditure & 43.1 & 46.1 & 49.7 & 36.3 & 33.9 \\
\hline Non-oil primary balance & -28.7 & -28.0 & -31.8 & -17.7 & -14.8 \\
\hline \multirow[t]{2}{*}{ Overall fiscal balance } & 6.7 & -20.8 & -10.6 & -1.0 & -1.6 \\
\hline & \multicolumn{5}{|c|}{ (Billions of CFAF) } \\
\hline Nominal GDP & 3,740 & 3,228 & 3,758 & 4,032 & 4,361 \\
\hline Nominal non-oil GDP & 2,030 & 2,142 & 2,369 & 2,587 & 2,937 \\
\hline
\end{tabular}

Sources: Chadian authorities; and IMF staff estimates and projections. 


\section{Statement by Mr. Rutayisire on Chad \\ (Preliminary) \\ Executive Board Meeting \\ June 16, 2010}

I would like to express my Chadian authorities' appreciation of the continued engagement of Fund staff with Chad and their policy advice, including through the recent Staff-monitored program (SMP). I also thank Management for maintaining a frank and constructive dialogue with my authorities throughout difficult domestic circumstances.

In spite of the oil stream that begun in the early 2000s, Chad continues to face considerable challenges, notably unfavorable social indicators (education, health, quality of water) and significant infrastructure gaps (electricity, roads, agriculture capacities, etc.). This economy also continues to be adversely affected by difficult weather conditions, particularly drought, and by long-standing security problems - although my authorities have made efforts on this front through a recent rapprochement with a neighboring country to address the security crisis caused by the lingering Darfur conflict. The security situation has heavily weighted on the mixed performance under the 2009 SMP. My authorities strongly believe that the country's medium-term growth prospects partly rest with addressing the security problems, which requires considerable resources. They intend to build on recent progress to tackle the security challenge more forcefully and meet the country's infrastructure needs. In their new Poverty Reduction Strategy adopted in April 2008, my Chadian authorities highlight the importance of restoring security, ensuring fiscal sustainability and sound public financial management, and improving the quality of spending to promote economic diversification and reduce poverty.

In the short term, my authorities are induced to respond to an immediate humanitarian challenge stemming from food shortages, and to other priority outlays, while at the same time reflecting on medium-term fiscal and structural challenges to boost the country's economic prospects. They hope that they can count on the Fund to support their efforts, and they remain open to discuss ways forward to restore financial relations with the Fund and resume progress towards the HIPC Completion point, with the view to free up scarce resources needed to advance towards the MDGs and tackle poverty in a significant manner.

\section{I - RECENT ECONOMIC DEVELOPMENTS}

The economy of Chad has suffered in 2009 from a steep reduction in agricultural production due to poor rainfall and decrease of oil production, which translated into a 2-percent economic contraction. Inflation has increased to double digits last year due to adverse weather conditions, public spending, and international price and exchange rate movements, before receding somewhat in the aftermath of the food and fuel crisis.

As a result of the economic downturn, the fiscal position deteriorated as the government used counter-cyclical spending measures while oil revenues fell, prompting it to use savings held at the regional central bank BEAC, to tap on the counterpart of Chad's new SDR allocations, and to have recourse to foreign financing - mostly in the form of grants - to finance projects 
implemented by donors. At the same time, my authorities have enhanced non-oil tax revenues which reflected in an improvement - albeit small - in the non-oil primary balance for 2009. Chad's balance of payments also weakened and gross official reserves declined as a result of decreasing oil prices.

As macroeconomic developments largely responded to the unfavorable domestic and external shocks, little progress could be achieved in addressing the financial needs of the state-owned cotton company which has suffered losses stemming from low world cotton prices and declining production. Likewise, the budget problems facing the utilities (water and electricity) company and which continue to cause frequent power outages should be dealt with.

\section{II - POLICIES FOR 2010}

For the remainder of 2010, the authorities will put emphasis on tackling immediate humanitarian and economic challenges. As indicated above, they will build on recent progress to further improve the security situation. They also strive to address the problem of food shortages and respond to the spending pressures caused by other short-term priority outlays. They intend to achieve these objectives through a supplementary budget, which financing they have secured.

\section{Reducing security-related uncertainties}

My authorities are of the view that further progress in reducing security problems is instrumental to alleviate the fiscal burden. They are ready to put the necessary resourceswhich are significant - to this end. They expect that the improvement in the security situation would boost non-oil economic activity and non-oil revenue, and allow a decline of security spending.

\section{Addressing the food shortages}

My authorities share the view on the need to address the food supply problem through both short-term measures to tackle the immediate shortage and long-term reforms to enhance agricultural productivity and output. In the short-term, as about 2 million people in Chad could face hunger, the Chadian government has decided to use the country's stock of 10,000 tons of food and ordered an additional 33,000 tons at a cost that amounts to nearly 1 percent of non-oil GDP. They also count on the donor community to finance additional food supply, which delivery is coordinated by the World Food Program.

\section{Other immediate priority outlays}

Chad also faces significant spending pressures owing to upcoming legislative (end-2010) and presidential (April 2011) elections, ongoing investments to close infrastructure gaps, and payments of arrears and other liabilities. The authorities are prepared to meet all these immediate outlays through the supplementary budget, which must carry appropriate resources. 


\section{III - MEDIUM-TERM CHALLENGES}

\section{Coping with the trend decline in oil revenues}

My Chadian authorities are fully aware of the fiscal, debt and development challenges expected from the trend decline in oil resources. They agree that the fiscal situation-which has already become tight-will further pose challenges going forward. That said, they believe that, at the current stage, tighter fiscal policy could be counterproductive in sustaining recovery from the recent global shock and unresponsive to the important investment needs facing the country. My Chadian authorities continue to reflect on the medium-term macroeconomic outlook, which must take into account the expected improved security situation, developments in oil prices, the discovery of new oil fields and other natural resources. They hope that Fund staff will continue to propose quality policy advice that factor in all these elements.

Addressing the country's limited absorptive capacity is also critical to Chad's meeting its infrastructure gaps. The Chadian government welcomes any technical assistance from donors that is aimed at helping them design a multi-year investment framework and improve public financial management. Furthermore, my authorities share staff's views on the need to maintain mechanisms (Petroleum Revenue Management framework; ongoing actions under EITI; etc.) that ensure transparency in the oil sector. They also look forward to further enhancing non-oil tax revenues through tax administration reforms and simplification of tax and customs codes; better aligning spending with priorities set forth in the country's Poverty Reduction Strategy; and improving budget execution. In this regard, donors' technical assistance will be of essence.

\section{Financial sector}

My authorities are cognizant of the financial sector vulnerabilities, notably the lack of financial depth, the fragile situation of some banks, and the underdeveloped regional financial markets. They will continue to strengthen their cooperation with the regional banking supervisory body, COBAC, to tackle bank solvency problems.

\section{Structural reforms}

The authorities recognize that there is considerable room for improving the country's business climate. Apart from efforts to enhance security and improve the soundness and functioning of the financial sector, they view the strengthening of the judiciary system and the resolution of the problems facing the energy and cotton sectors as essential for enhancing the business environment and alleviating the fiscal burden of those sectors. 